\title{
السياق وأثره في فهم مقاصد الشارع
}

نجم الدين قادر كريم الزنكي

\section{مقدمة}

تصدى الباحثون القدامى والمحدثون لدراسة المقاصد، فبينوا معناها الاصطلاحي، و كشفوا النقاب عن سبل استخر اجها واستقر ائها والاستفادة منها، و أشارو ا إلى وسائل عدة تمهد للباحثين طرق التوصل إليها من خلال النصوص وعللها، واستقراء تصرفات

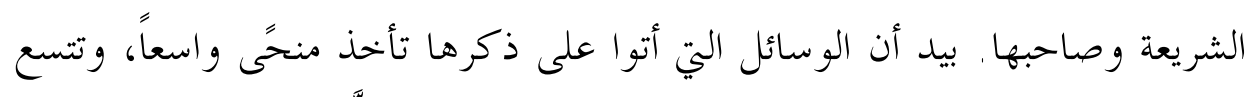

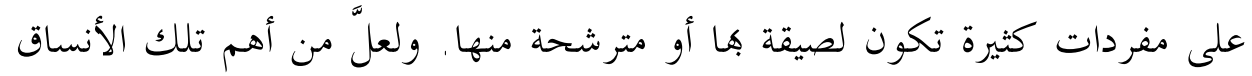
مفردة السياق. فهو يمثل ببعديه المقالي والمقامي واحدة من المفردات العلميَّة التي تلقي

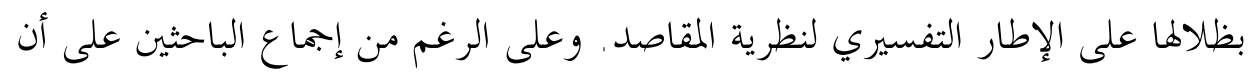

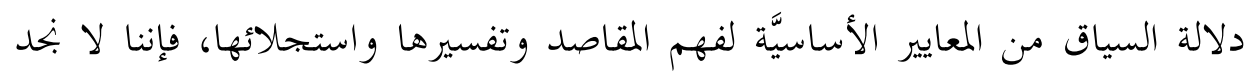

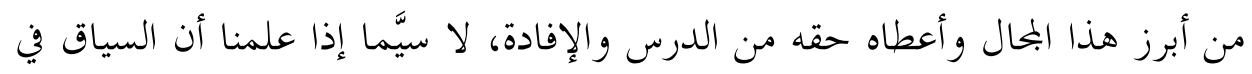
أحد إطلاقيه الشائعين قد جاء.معنى الغرض الذي ورد النص من أجله أو الفائدة التي خرج الكالام من أجلها، فهو لذلك شديد الصلة بالمقاصد، بل مفردة أبجدية في قاموسها.

تعود أهمية هذه الدراسة إلى أها عقدت وأعلنت القران بين مصطلحين رائجين في بحال الدراسات الأصولية قديماً وحديثاً، وإلى أها مساهمة في وضع لعند لبنة أساسية من

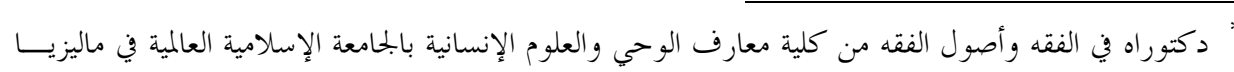

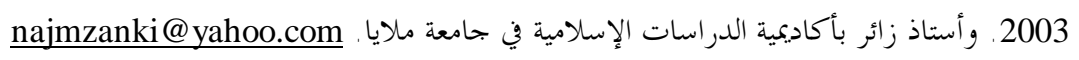


36 إسلامية المعرفة، السنة الثانية عشرة، العدد 48، ربيع 1428هـ/2007م بخم الدين قادر كريع الزنكي

لبنات النظر المقاصدي وفق أولوياته العلمية وانطلاقاً من أبجدياته ومسلماته البدهية. فقد توجهت همم الباحثين إلى درس المقاصد وتطبيقها وممارستها في ميادين الفقه

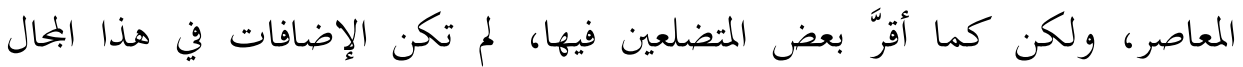

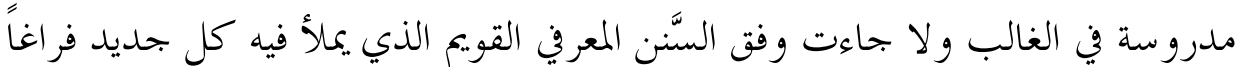
في البنيان الخاص، وحيزاً في الهيكل العام، وإنما جاءت مبعثرة في كثير من الأحيان.

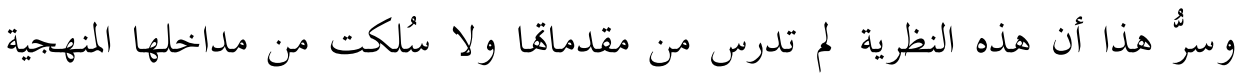

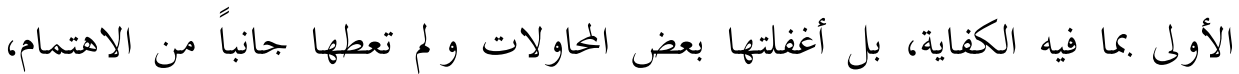

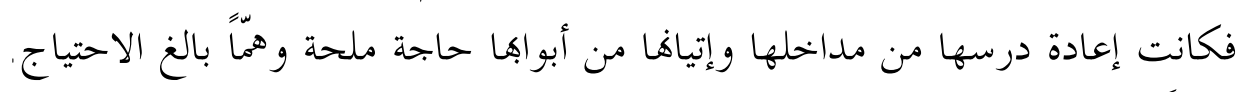

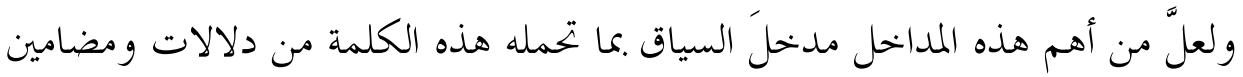
تتسع على مسلمات لغوية ودلالية وتنبسط على مفردات التخاطب من الخطاب نفسه

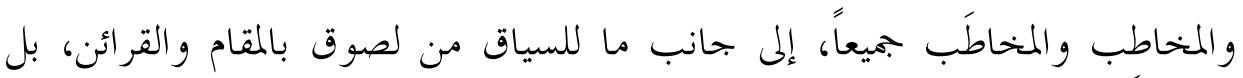

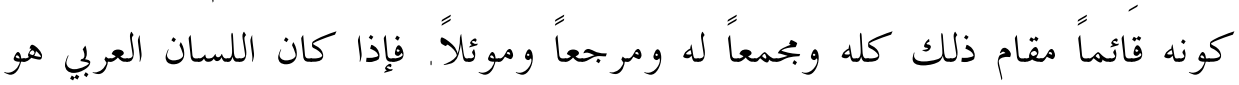
المترجم عن مقاصد الشارع، فإن السياق هو المترجم عن هذا اللسان وأغراضه وبيانه.

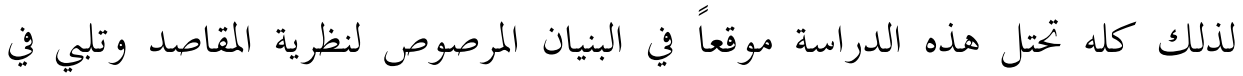
أكناف الدرس المقاصدي حاجة ضرورية ملحة. وبجانب هذا، فإن لدرس السياق

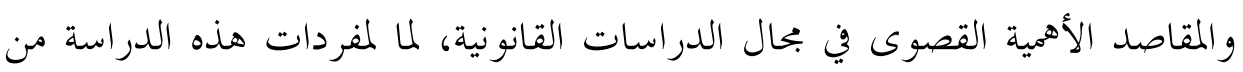
مالامسة لأهداف المشرعين و أغراض المشترعين، ولمس لمباني القوانين ومغازيها وغاياها العليا. و القانون كالشريعة يترجمه اللسان ويعبر عنه، وقد اختلفت مدارس التفسير في القانون إلى المدرسة الحرفية التي تلتزم النص، والمدرسة التأريخية الاجتماعية، والمدرسة العلمية، 1 وبين هذه المدارس أوجه وفاق وخحلاف، ولكل منها اعتبارها في تقدير النص وروحه وهدفه، وفي تقدير العلاقة بين ظاهر النص وغايته، وفي مسارات التطبيق على

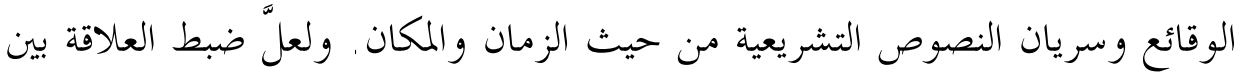
السياق و المقاصد وتكوين رؤية علمية مؤصلة في ذلك، يخلق وعياً جديداً في إطار 1 أبو السعود، رمضان. الوسيط في شرح مقدمة القانون المدني - المدنخل إلى القانون وبخاصة المصري واللبناني،

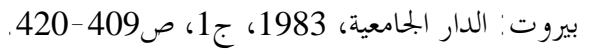


تكييف العلاقة بين النص وغرضه، ويقلل هوة الخلاف القائم بين هذه المدارس،

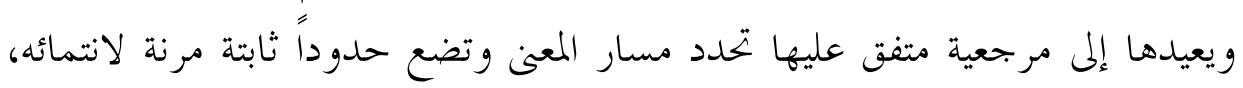

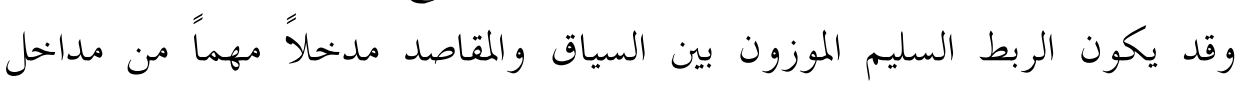

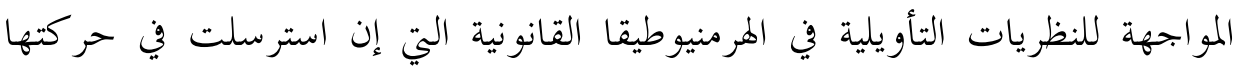
تآكلت القوانين فيما بينها، وتضاربت القيم التشريعية والكونية الثابتة في جنبها، واضمحلت عن القانون آفاق الاستقرار الذي يمفظ كيان الجماعة ويصون كرامة الأفر اد ويقدم للمجتمعات فرصة التقدم بخطى ثابتة لا تتعثر .

يي هذا البحث سيتم جلب النظر إلى تلك العلاقة التفسيرية المتينة بين نظريتي السياق والمقاصد، وذلك من خلال الوقوف على معاني المصطلحين، وبحالات تداخلهما، لننطلق منه إلى بيان ما للأدوات والأشراط السياقية والأحكام التصورية الأصولية للدلالة السياقية من أثر على فهم المقاصد ودورها في بتلية معنى النص وبناء نواة المعنى فيه. و ستكون لنا وقفة أمام المقاصد الأصلية و التبعيَّة بإزاء ما اصطلح فيلح عليه الأصوليّون في مباحث الدلالات من السَّقّق الأصلي والسوّق التبعي، لنقيم على إثره جدلاً علمياً حول طبيَّ في مباحة العلاقة بين السياق و المقاصد.

لذلك نوزع البحث على أربعة محاور و خاتمة، كما يأتي: الخور الأول: وقفة في موضوع البحث ومفرداته. المحور الثاني: بناء النظم وعلاقته بالمقاصد. المحور الثالث: التصور الأصولي لأحكام السياق وأثره في فهم المقاصد وتفسيرها. المحور الرابع: تصورات تحليلية في الصلة بين السياق والمقاصد. الخاتمة: تلخيص نتائج البحث. 
38 إسلامية المعرفة، السنة الثانية عشرة، العدد 48، ربيع 1428هـ/2007م بخم الدين قادر كريع الزنكي

أولاً: دلالة مصطلح السياق ودوره في درك مقاصد الخطاب

\section{1 دلالة المصطلح}

المقاصد جمع مقصد. وهو اسم مصدر من الفعل (قصد يقصد قصداً). وقدد أتت

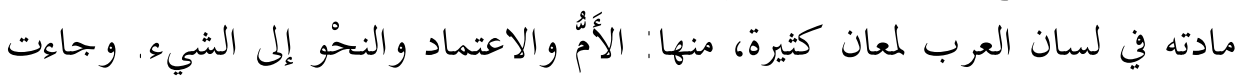

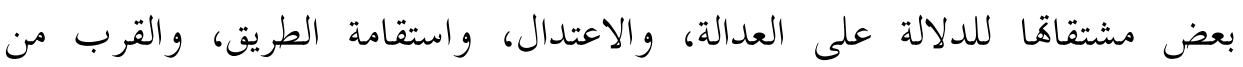

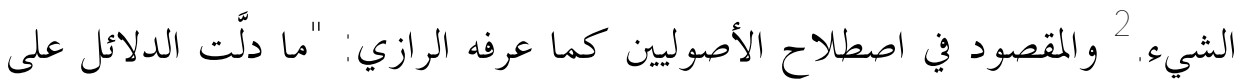

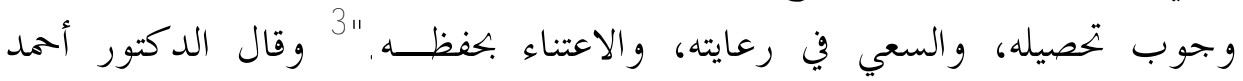

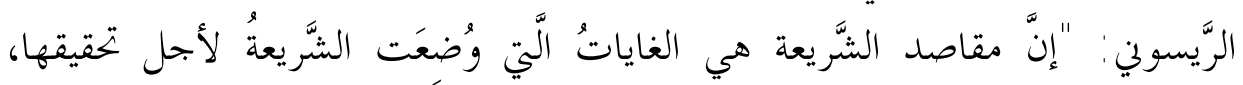

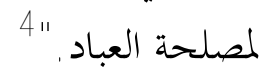

أما السياق فقد وردت مادته في اللغة العربية للدلالة على معنى السرد و السلسلة والإيراد وبحيء الشيء متتابعاً. تقول العرب: ساق الإبل سوقاً وسياقاً إذا سردها سرداً

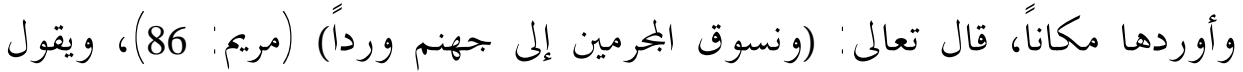

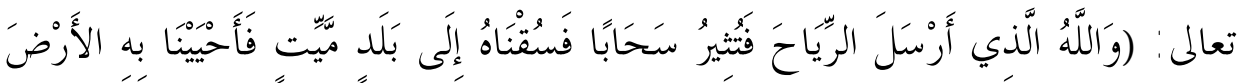

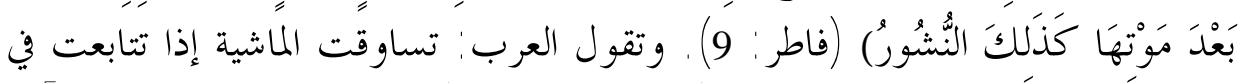

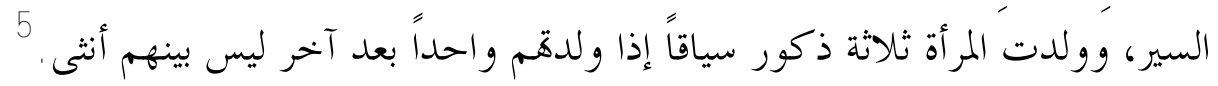
و لم أعثر للسياق على تعريف اصطلاحي صريح في تراثنا اللغوي والأصولي،

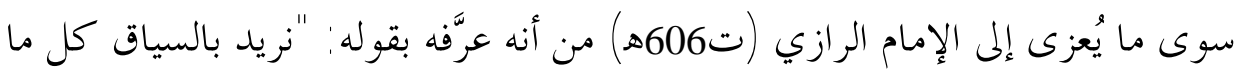
يكتنف اللفظ الذي نريد فهمه من دو الّ أخرى."

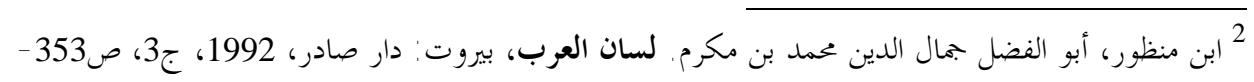

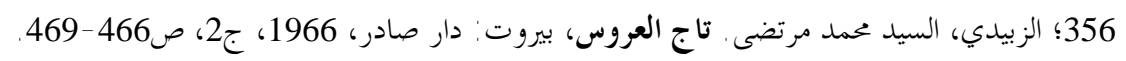

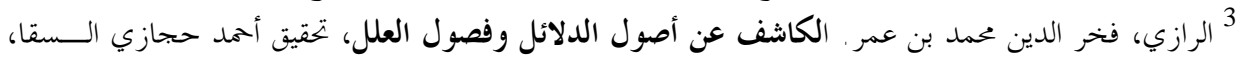

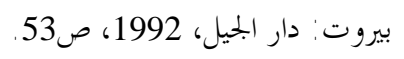

4 الريسوني، أحمد. نظرية المقاصد عند الإمام الشاطبي، ط4، فيرجي، صينيا: المعهد العلمي للفكر الإســامي، 1995، ص19.

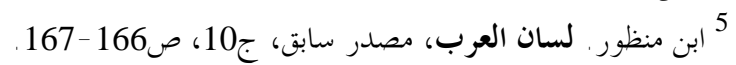

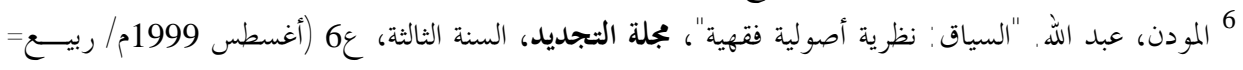


بيد أن هناك تعاريف عديدة التخت بيان المنحى الوظيفي للسياق وسيلة إلى

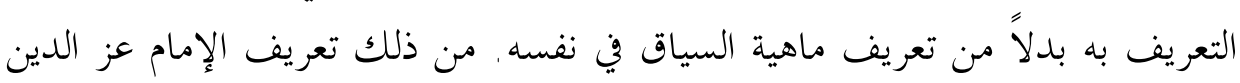

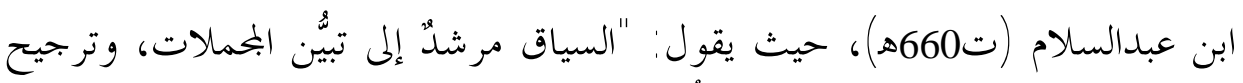

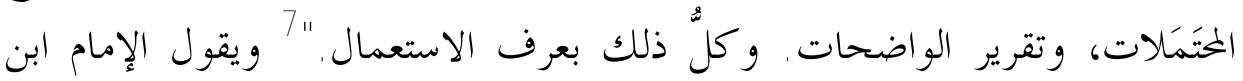

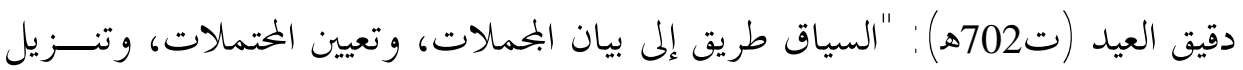

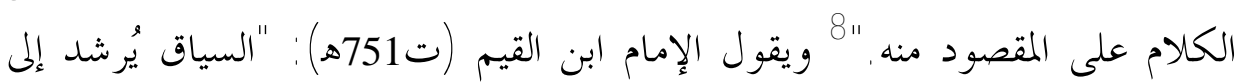

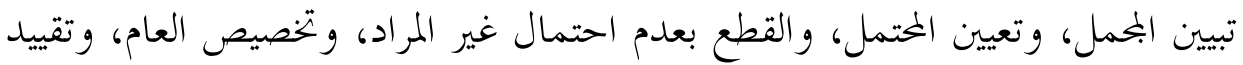

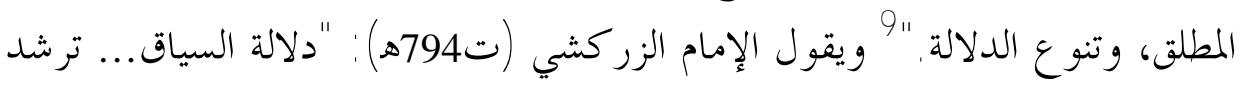

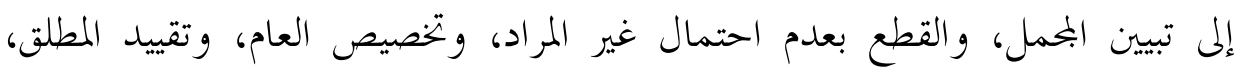
وتنوع الدلالة."10

وللمحَدَثين تعاريف شتى تكاد تكون متفقة في الجوهر مع تعريف الإمام الرازي،

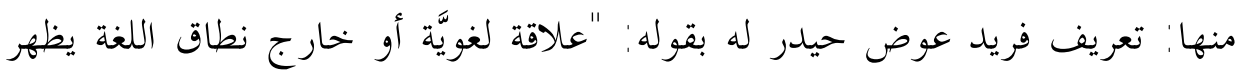

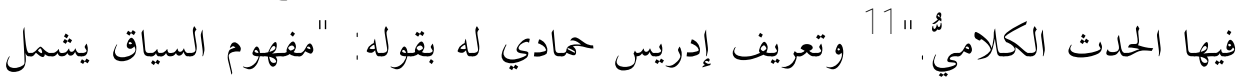

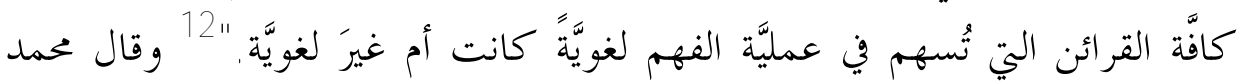

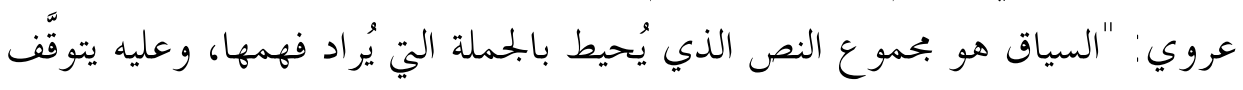

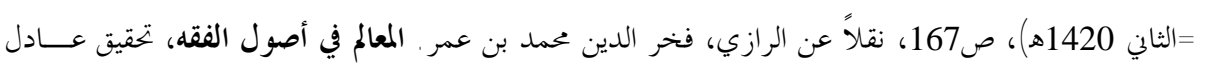

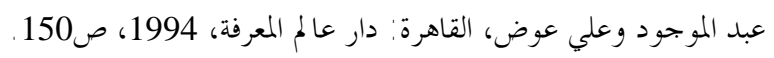

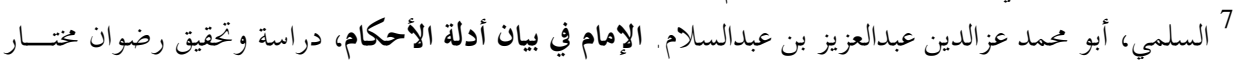

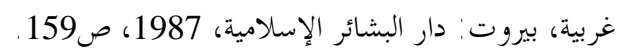

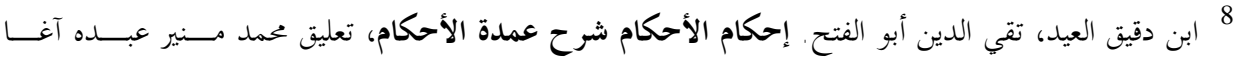

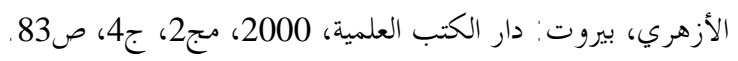

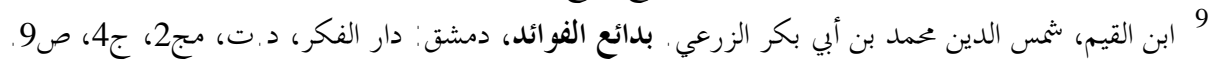

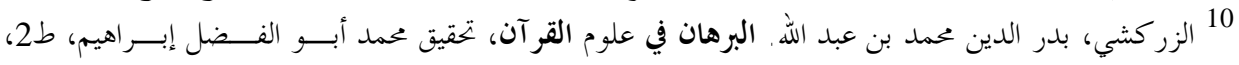

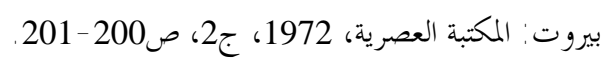

11 حيدر، فريد عوض. علم الدلالة: دراسة نظرية وتطبيقية، القاهرة: مكتبة النهضة المسرية، 1998، ص157،

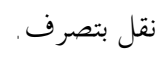

12 ممادي، إدريس. الخطاب الشرعي وطرق استثماره، بيروت: المركز الثقافي العربي، 1994، ص146. 


\section{الفهم السليم ها، أو هو المحيط الذي أُنتجت فيه العبارة."13}

وتكاد تتفق عبارات المحدثين وعبارة الرازي على معنى جامع يتمثل في أن السياق

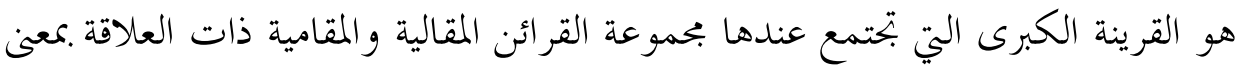

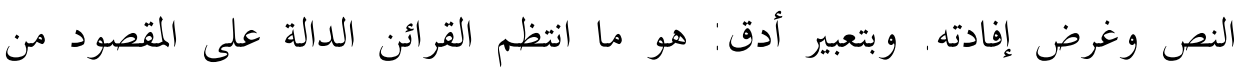

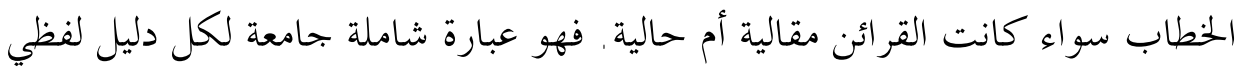
و وعنوي وحالي يفسر الغرض من الخطاب. ومن هنا فإن السياق يمكن أن ينقسم باعتبار القرائن التي يمويها إلى سياق مقالي وسياق مقامي. ويراد بادئ بالسياق المقالي

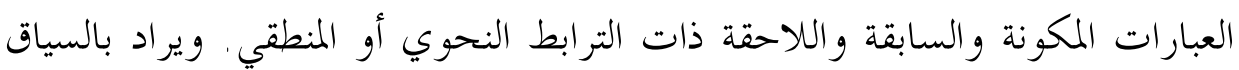

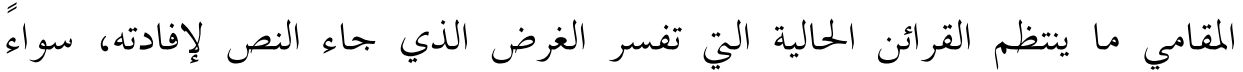

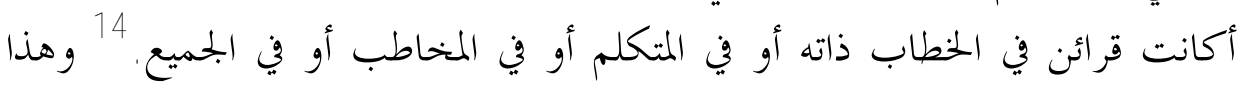

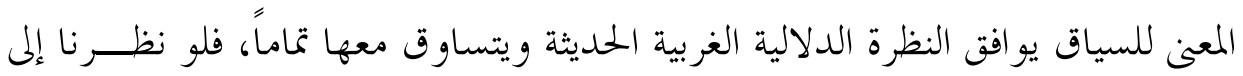
تعريف الســياق: "Context" في قاموس: " Language Teaching and Applied Linguistics

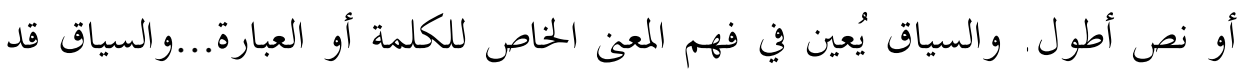

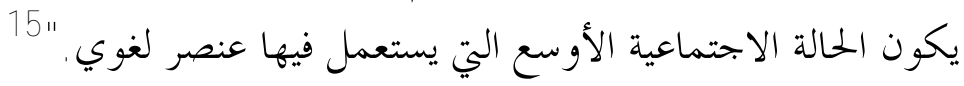
وذلك يعني أذهم لا يقابلون كلاًّ من القرائن اللغوية والقرائن المقاميَّة .مصطلح

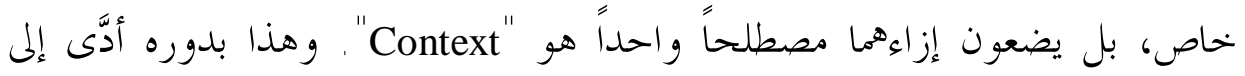

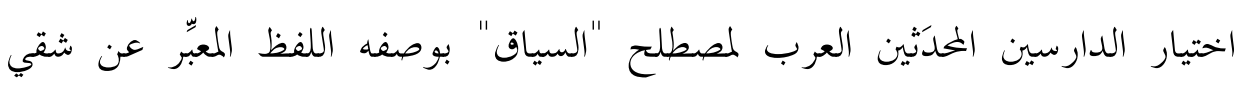

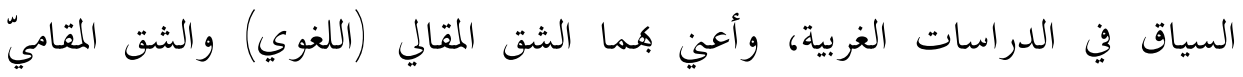
(الاجتماعي). ولقد وجد الباحثون العرب أن المعنى اللغوي لمادة "السياق" في المعجم

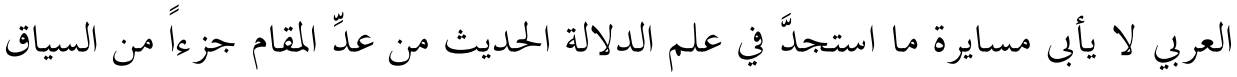

13 عروي، محمد إقبال. "الوظيفة الترجيحية للسياق عند المفسرين"، (بجلة آفاق الثقافة والتراث)، ع35، الــسنة

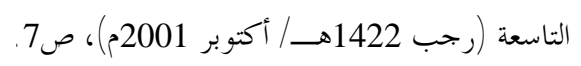

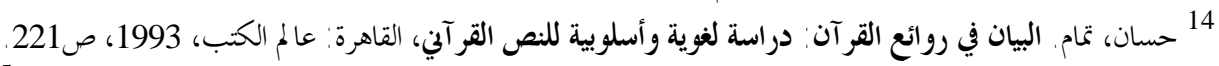

${ }^{15}$ Richards, Jack and others, Longman Dictionary of Language Teaching and Applied Linguistics (Malaysia: England Longman, fourth edition), 1995, p.82. 
ونوعاً من أنو اعه، وفي هذا يقول محمد عروي: "يُستعمل مصطلح السياق في سياقات

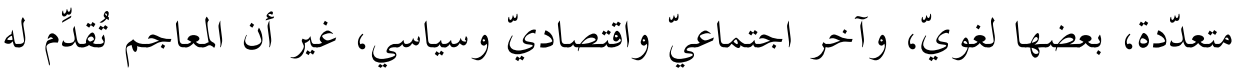

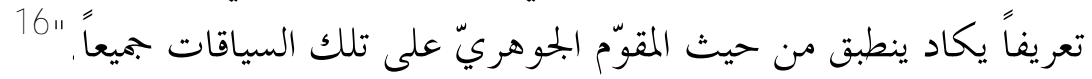

\section{2. دور السياق في درك مقاصد الخطاب}

لتوضيح مناحي الإفادة السياقية في تجلية مقاصد الشارع من خطابه ينبغي استحضار حقيقة جوهرية تتعلق بإطلاقات الأصوليين للفظة "السياق" ومشتقاته، لنحدد في ضوئها ما له من أثر في فهم مقاصد الشرع و استكشاف أغراض الخطاب. و بالتأمل و النظر في إطلاقات علماء الأصول لهذا المصطلح يظهر أنه جاء.معنيين:

المعنى الأول: ما يكوِّن العبارة أو يسبق اللفظ أو يلحقه من قرائن لفظية. وبتعبير

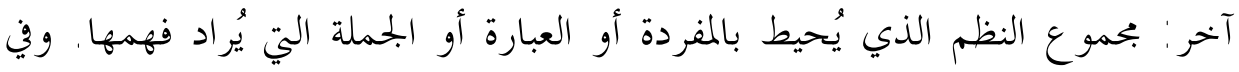

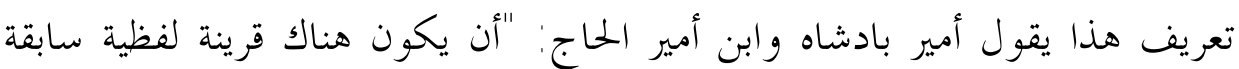

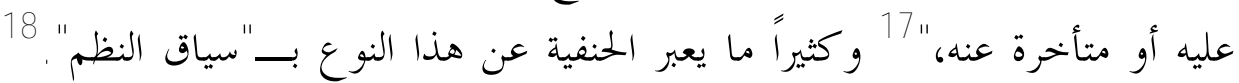
والسياق هذا الإطلاق يشمل جميع عناصر التركيب العربي وأشراط تكوينه وإفادته

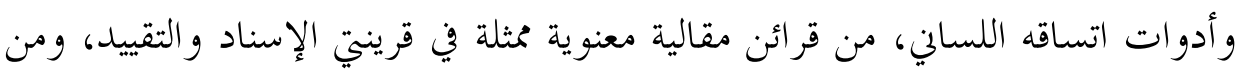
قرائن مقالية لفظية ممثلة في قرائن الإعراب والرتبة و الصيغة الصرفية والمطابقة والربط

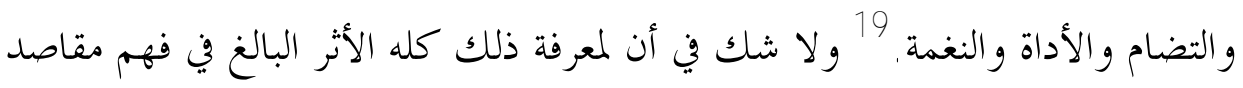

16 عروي، "الوظيفة الترجيحية للسياق"، مصدر سابق، ص7.

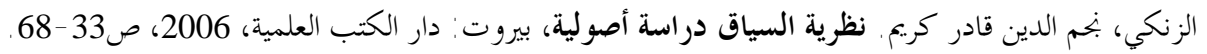

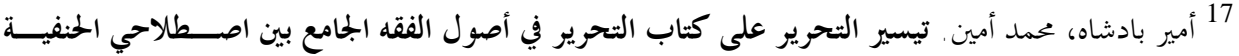

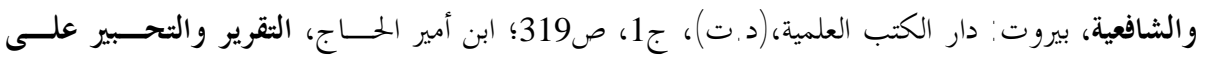

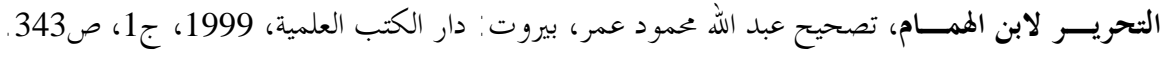

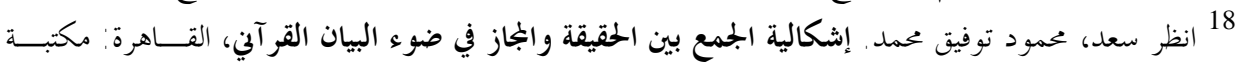

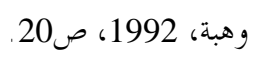

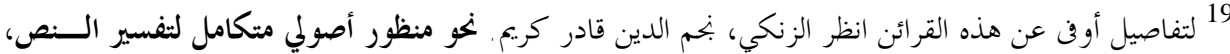

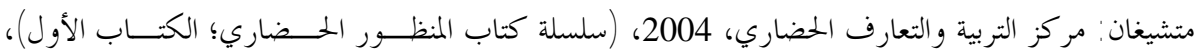


42 إسلامية المعرفة، السنة الثانية عشرة، العدد 48، ربيع 1428هـ/2007م بخم الدين قادر كريم الزنكي

العرب من لساها المترجم عن مقاصد الشرع، فأثر السياق هذا الإطلاق في فهم

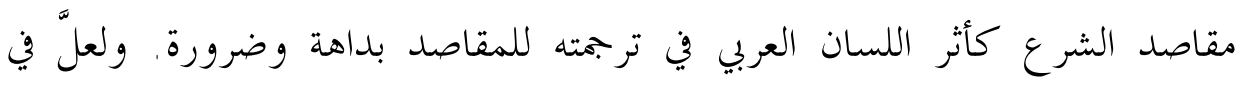
مبحث تخصيص العام بالأدلة اللفظية المتصلة خير شاهد على ما للسياق وأشراطه من ون دلالة على بيان مقصود الشارع من الخطاب.

المعنى الثالي: الغرض الذي من أجله ورد الخطاب. وبهذا الإطلاق يكون السياق

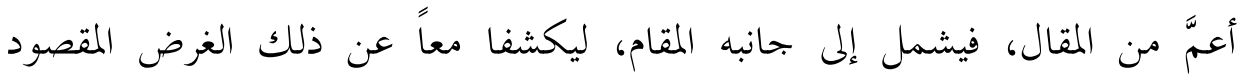
بالسَّوق . ولذلك تجدهم يقرنون "السياق" الوارد بهذا المعنى الثاني بلفظ "من أجل" أو لو

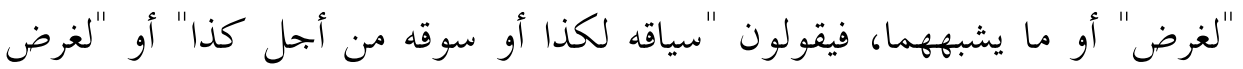
كذا" أو "المقصود بالسَّوق كذا"، أو يعبرون عنه بفعله "سيق" أو مصدره الميمي "مساق"، 20 للتمييز بين السياق المقالي الخاص، وهذا السياق الأعم الشامل للمقال

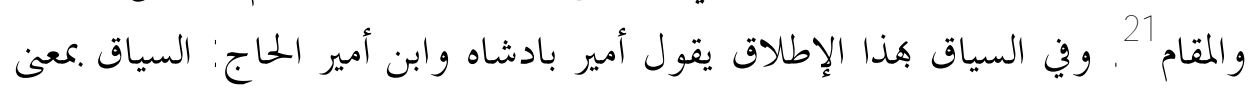

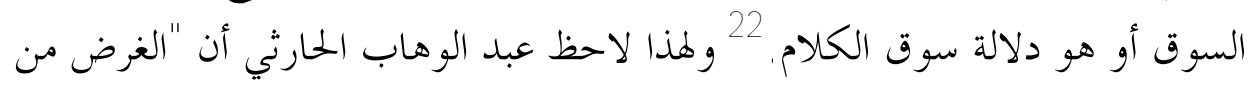
الكلام أو المعاني المقصودة بالذات هو العنصر الأساسي في مفهوم السياق."23

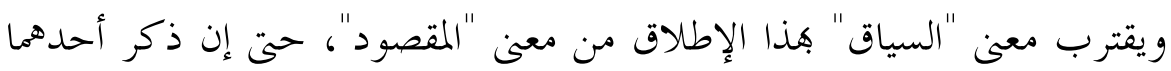

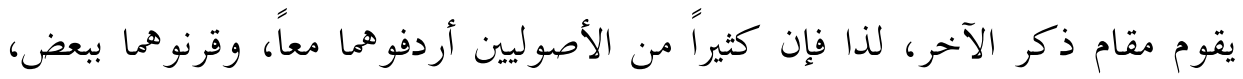

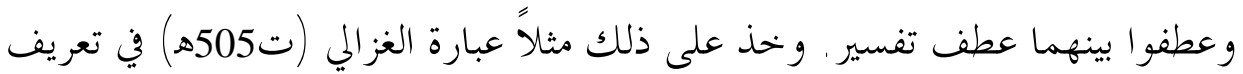

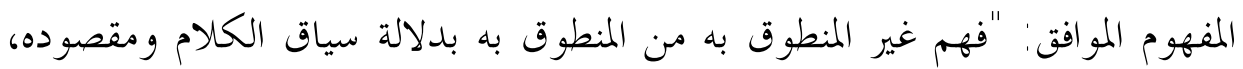

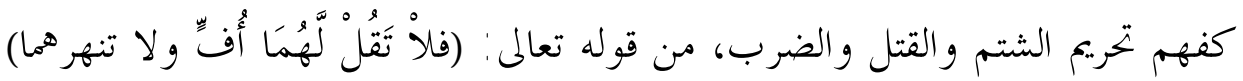

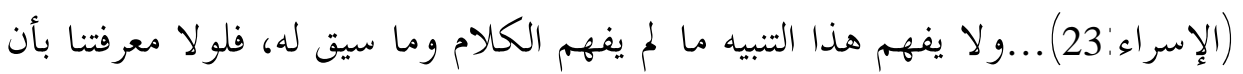

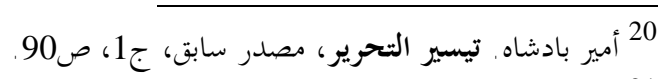

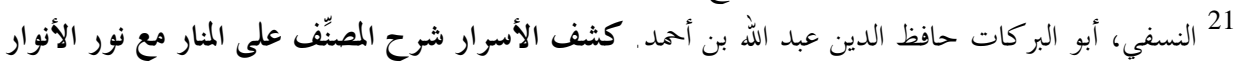

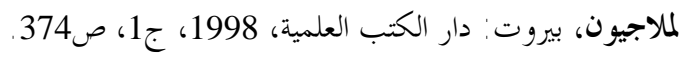

22 ابن أمير الحاج. التقرير والتحبيز، مصدر سابق، ج1، جار، ص343؛ أمير بادشاه. تيسير التحرير، مصدر سـابق،

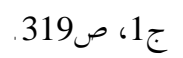

23 الحارثي، عبدالوهاب أبو صفية، دلالة السياق منهج مأمون لتفسير القر آن الكــريم، عمــان: دار المكتبــات

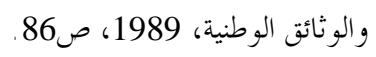


التأفيف."الآية سيقت لتعظيم الوالدين واحترامهما لما فهمنا منع الضرب والقتل من منع

معرفة دور السياق بالإطلاقين السابقين في تقاسيم النظم عند الحنفية25 يمكن.

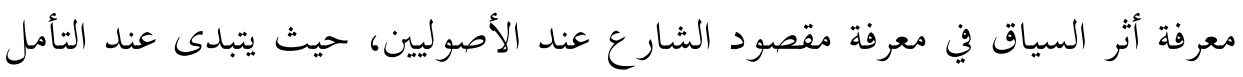

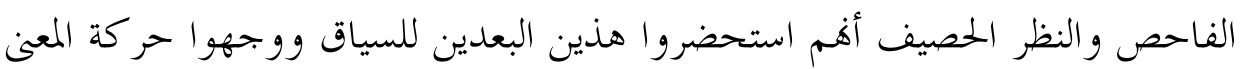

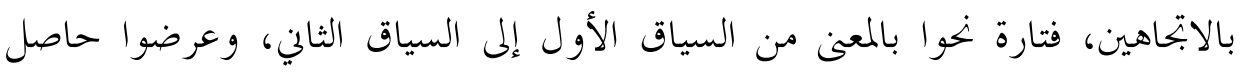

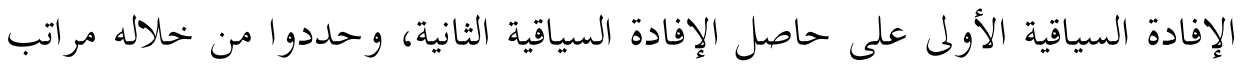

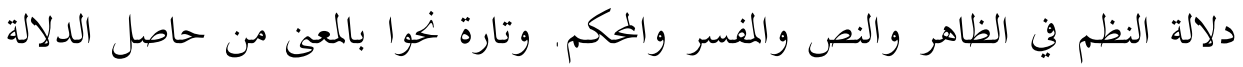

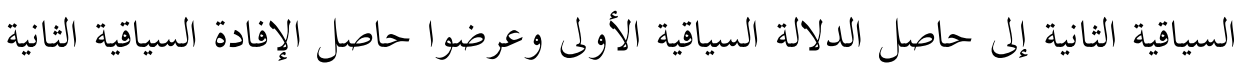

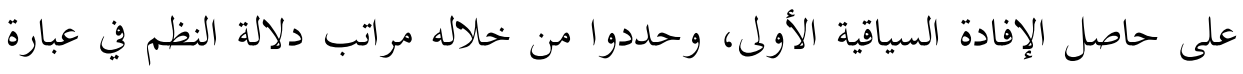

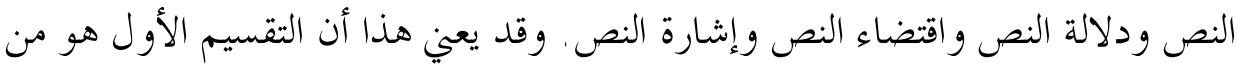

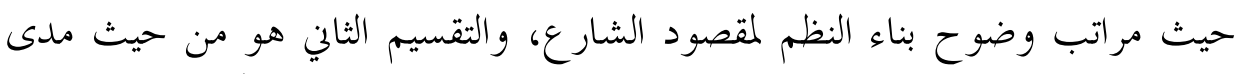

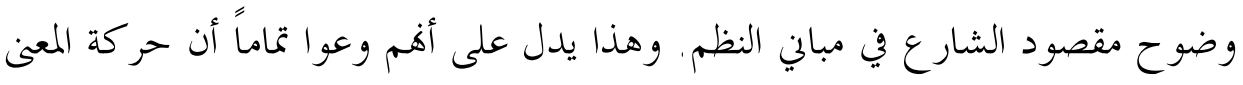

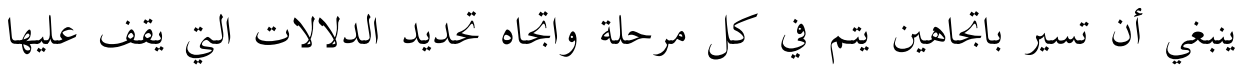

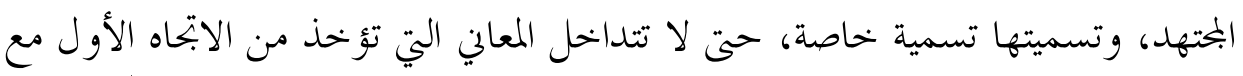

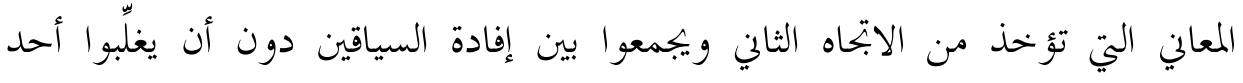

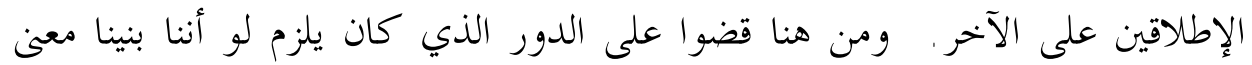

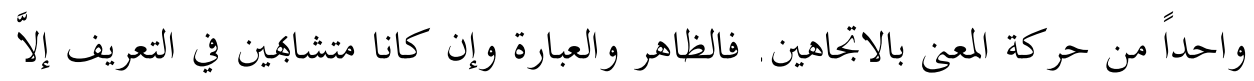

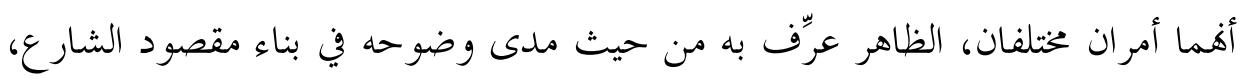

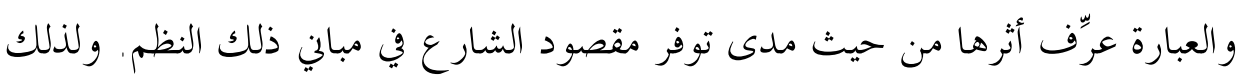
نذكر التقسيمين مع محاولة توضيح هذه المعالم التي أشرنا إليها في المور الئه الآتي:

24 الغزالي، أبو حامد عمد بن عمد. المستصفى من علم الأصول، تحقيق نخوى ضو، بيروت: دار إحياء التـراث

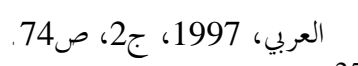

25 اقتصرت -هاهنا وفي الحور الآني - على تقسيم الحنفية للنظم، لأن فكرة السياق تتحلى فيسه بـشكل تسـوي،

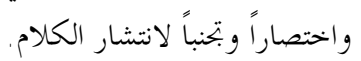


44 إسلامية المعرفة، السنة الثانية عشرة، العدد 48، ربيع 1428هـ/2007م بخم الدين قادر كريع الزنكي

\section{ثانياً: بناء النظم وعلاقته بالمقاصـــــ}

النظم من الألفاظ التي شاع استعمال الأصوليين لها .كعنى السياق . ويتردد معناه في

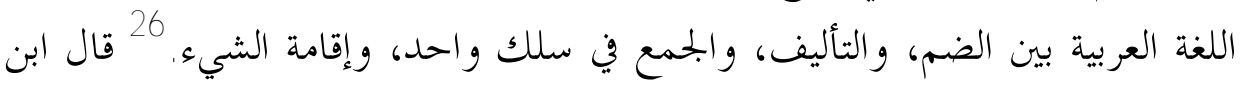

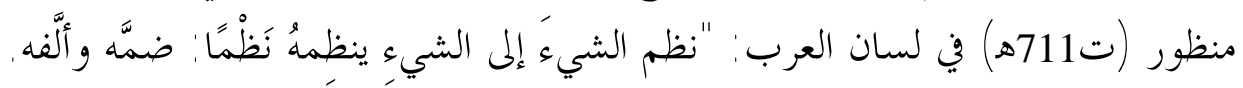

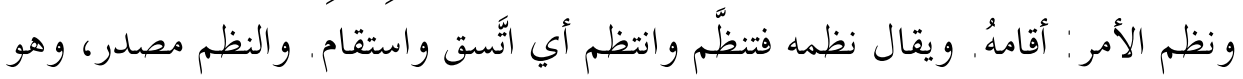

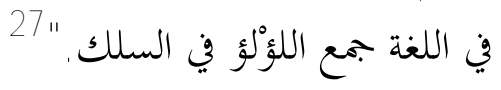
وثمة عدة تعاريف للنظم اصطلاحاً، أهمها ما يأتي:

(أ) عرّفه عبد القاهر الجرجاني (ت471هـ) بقوله: "أن تضع كلامك الوضع الذي يقتضيه علم النحو، وتعمل على قو انينه وأصوله، وتعرف مناهجه التي نُهجَتْ فلا تزيغ

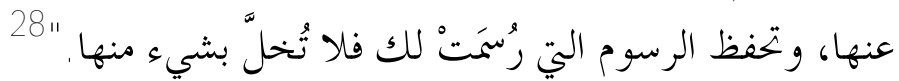

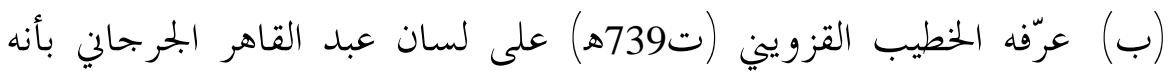
"تطبيق الكالام على مقتضى الحال."

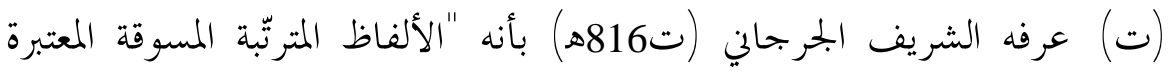
دلالتها على ما يقتضيه العقل.

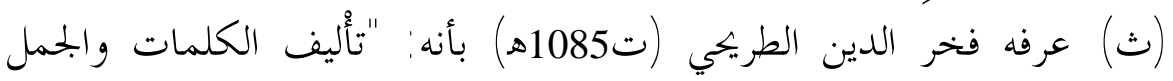

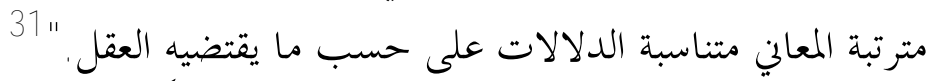
26 الزاوي، الطاهر أحمد. ترتيب القاموس الخيط للفيروز آبادي، القاهرة: عيسى البابي الحلبي وشــــاه، د.ت،

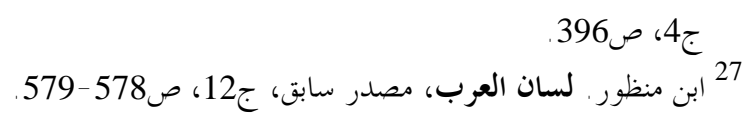

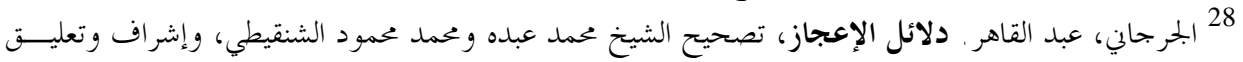

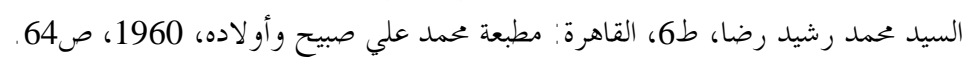

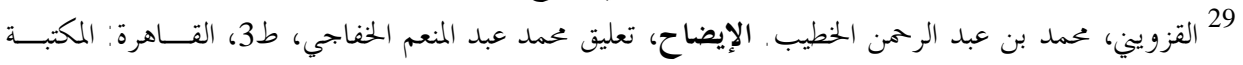

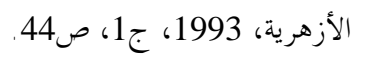

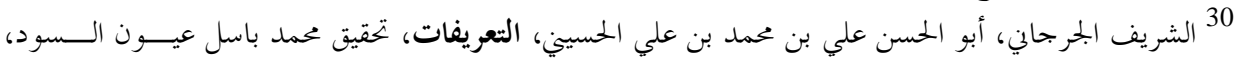

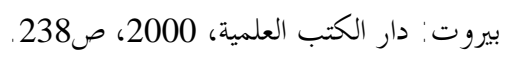

31 الطريجي، فخر الدين. مجمع البحرين، بيروت: دار مكتبة الهلال، 1985، ج6، ص176، صلئ. 
(ج) يذكر التهانوي (ت1158ه) أن النظم يطلق في الاصطلاح على أربعة معان،

- - بحسب اللفظ مفرداً كان أو مركباً، ومنه جاء تقسيم النظم إلى الظاهر

$$
\text { و النص وغير هما. }
$$

- - تركيب الألفاظ على وفق ترتيب يقتضيه إجراء أصل المعنى، حتى لو قيل في

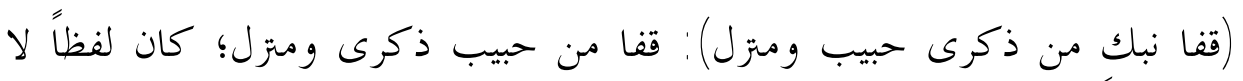

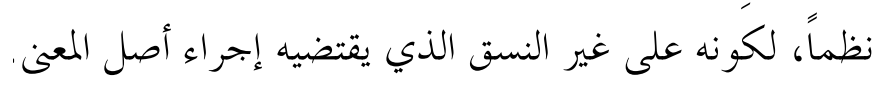

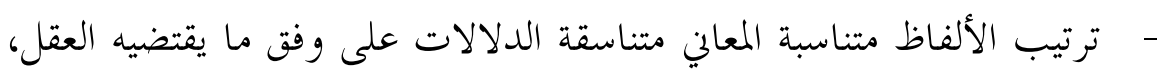

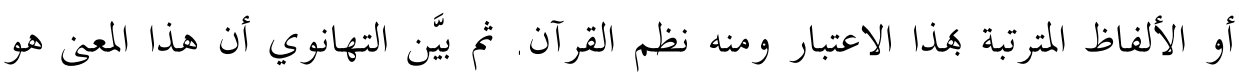

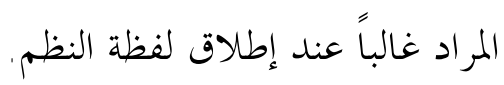
- الكام الموزون.

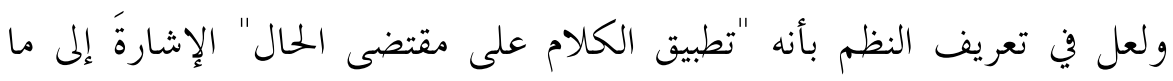

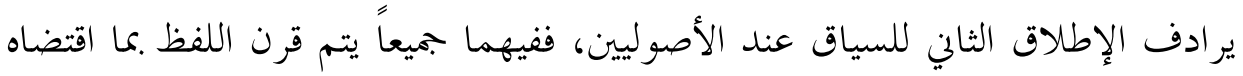

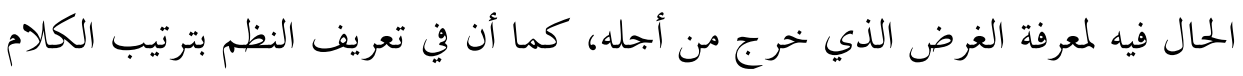

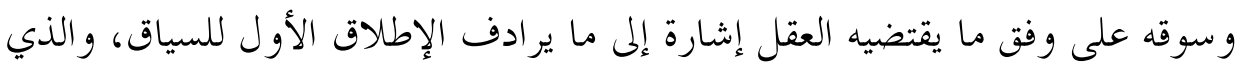

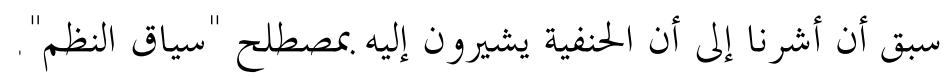
و.ما أن الحنفية أكثر تفصيلاً في بيان أقسام النظم من مدرسة المتكلمين ودفعاً

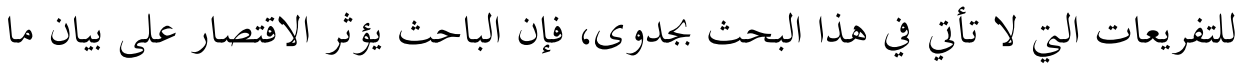

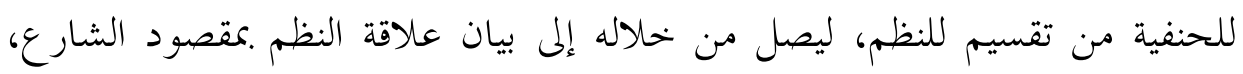

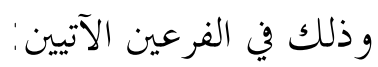

32 التهانوي، عمدا أعلى بن علي المولوي. كشاف اصطلاحات الفنون، بيروت، مطبعـة الخيــاط، د.ت، ج6، ص1428-1429. 
46 إسلامية المعرفة، السنة الثانية عشرة، العدد 48، ربيع 1428هـ/2007م بخم الدين قادر كريم الزنكي

\section{1ـ أقسام النظم باعتبار مدى وضوح بنائه لمقصود الشارع:}

قسم الحنفية النظم بهذا الاعتبار إلى الأقسام الآتية:

الظاهر: وهو كل لفظ يدل بصيغته على معناه من غير توقف على قرينة خارجية،

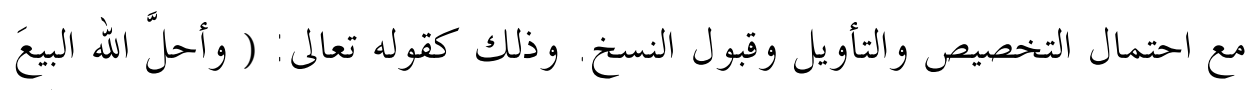

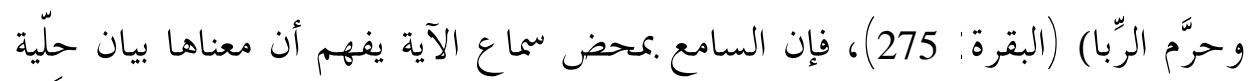

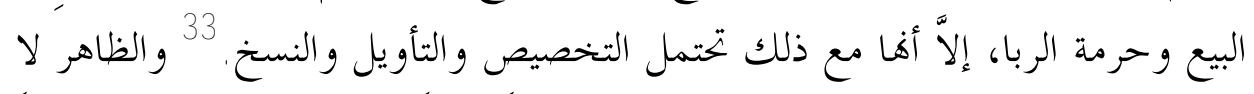

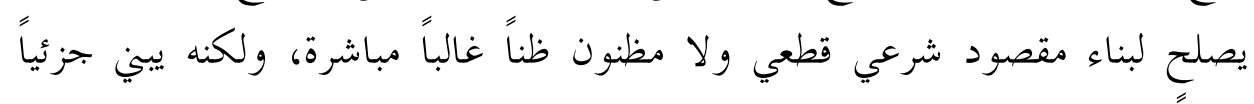

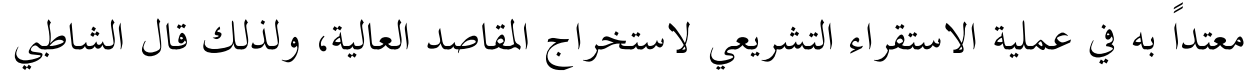
(ت790ه): "الاعتراض على ظواهر النصوص غير مسموع، والدليل عليه أن لسان

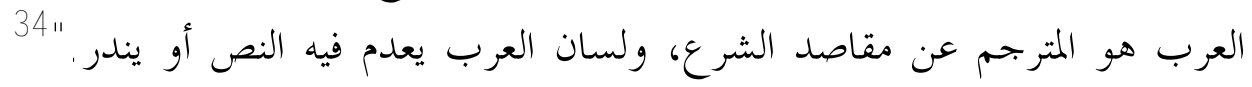
و يفهم من هذا أن الظو اهر هي مادة المقاصد التي تستخرج منها وإن كانت الظو اهر في وهن

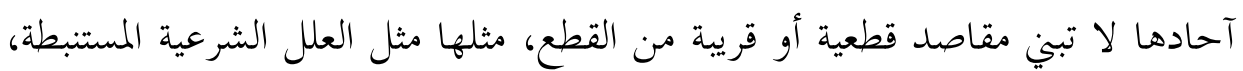
فهي لا تبني آحادها مقصداً شرعياً قطعياً أو قريباً من القطعي، ولئي، ولكنها مادة لاستقراء المقاصد العالية.

النص: وهو اللفظ الذي يدل على الحكم الذي سيق من أجله الكلام دلالة

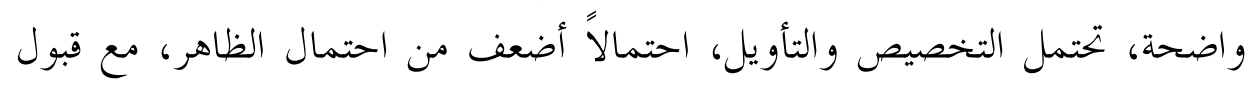

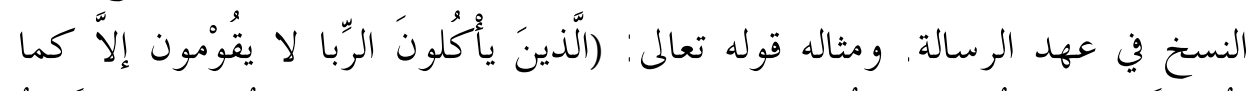

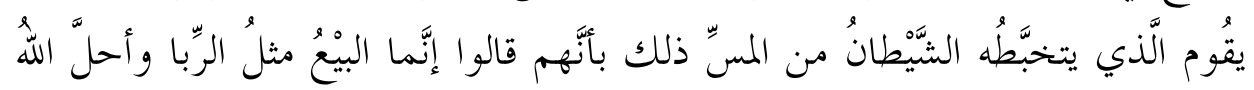

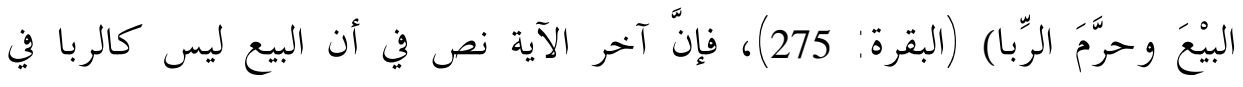

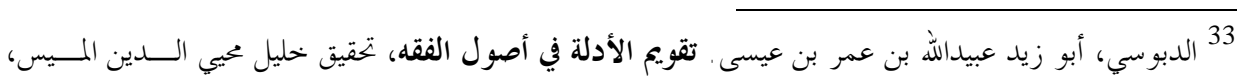

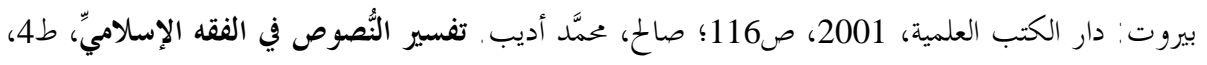

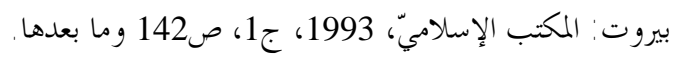

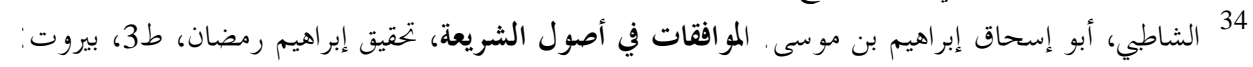

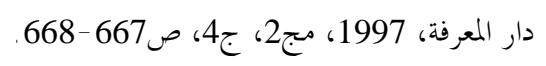

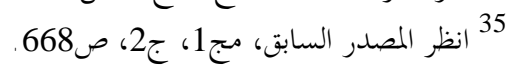


الحرمة، لأن سياقه يدل على كونه قد أورد من أجل الدلالة على هذا المعنى، فهو ظاهر

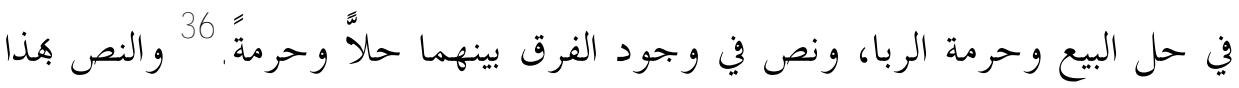

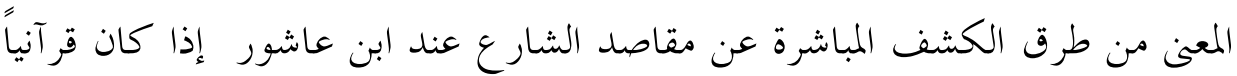

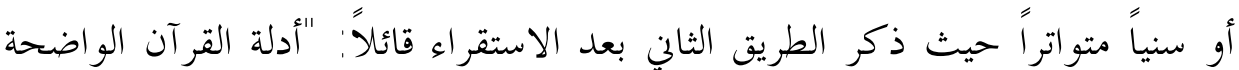
الدلالة التي يضعف احتمال أن يكون المراد منها غير ما هو ظاهرها بحسب الاستعمال

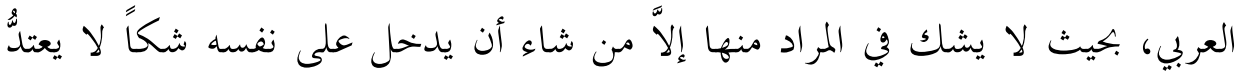

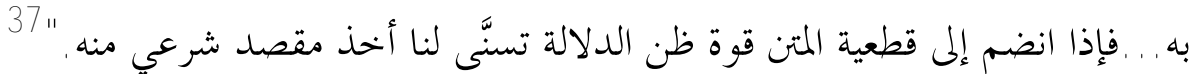
المفسَّر : هو اللفظ الذي يدلُّ على الحكم دلالة واضحةً، لا يبقى معها احتمال للتأويل أو التخصيص، ولكنه مما يقبل النسخ في عهد الرسالة، وله قسمان: الأول: المفسَّر الذي لا يحتمل التأويل والتخصيص لأجل معناه الوضعي، كأسماء

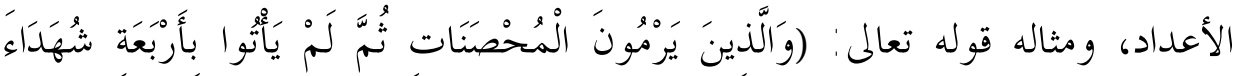

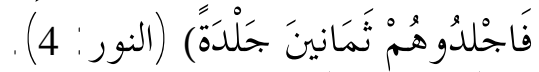

الثاني: المفسّر الذي انقطع عنه احتمال التأويل والتخصيص لأجل دليل قطعي، فهو ظاهر المعنى في نفسه، مفسَّر باعتبار ذلك الدليل القطعي. ومثاله قوله تعالى: (وَكلَّه

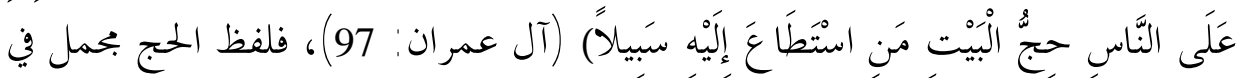

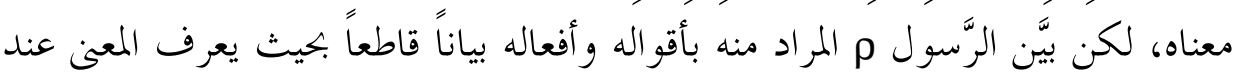
إطلاق لفظه على القطع و اليقين. 38

الغكم: وهو اللفظ الدال على معناه دلالة واضحةً لا تحتمل تأويلاً ولا تخصيصاً ولا

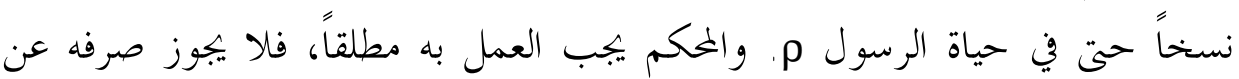

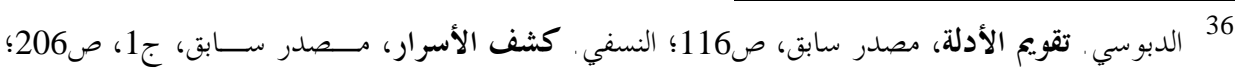

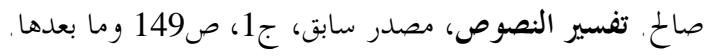
37 ابن عاشور، محمد الطاهر . مقاصد الشريعة الإسلامية، تحقيق محمد الطاهر الميساوي، (د.م: البصائر للإنتــاج

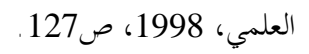

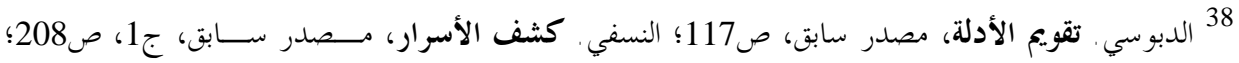

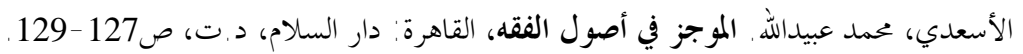


ظاهره إلى أي معنى آخر، كما أنه لا يحتمل النسخ، لذا يقدم عند التعارض على الأقسام

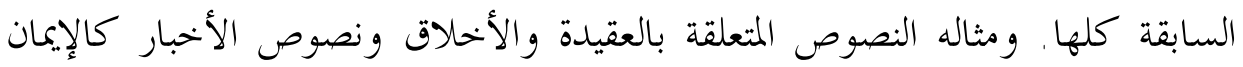
بالله ووحدانيته وحسن العدل وبرّ الو الدين و آيات القصص و الأخبار والجنة والنار . 39 ويفهم من تفرقة الحنفية بين الظاهر والنص بأن النص ما كان السوق من أجله

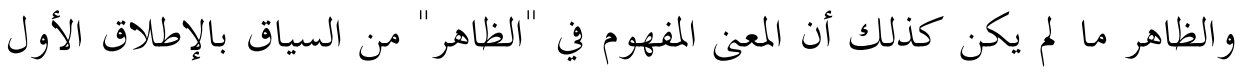

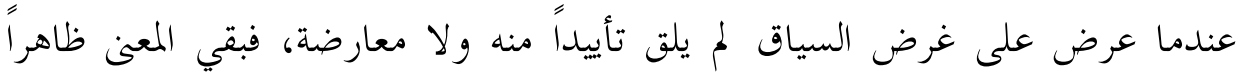

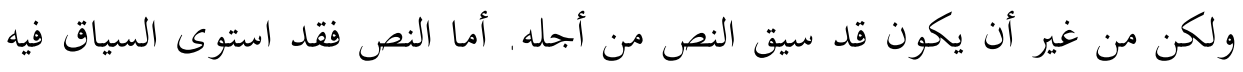

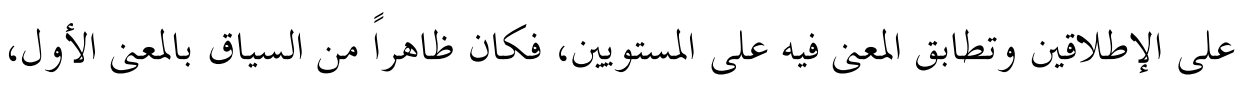

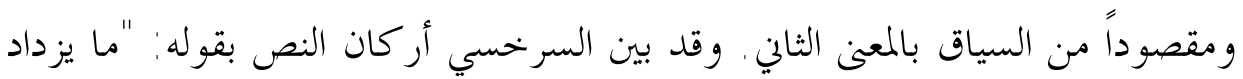

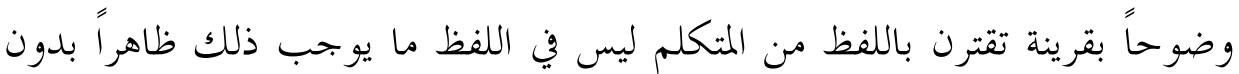

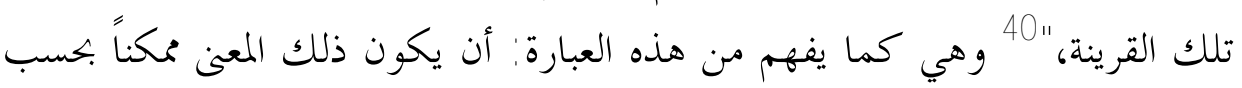

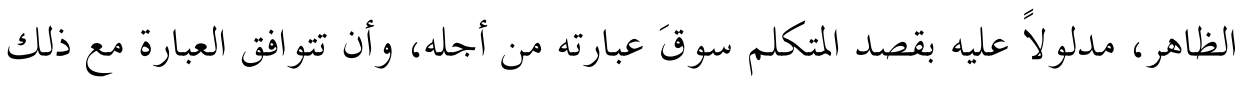

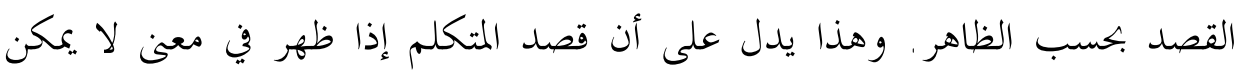

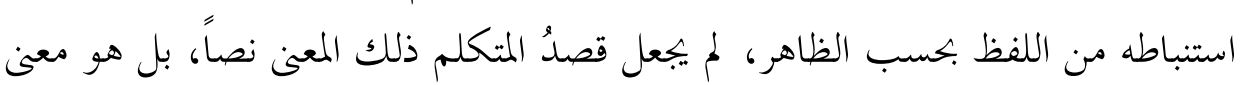

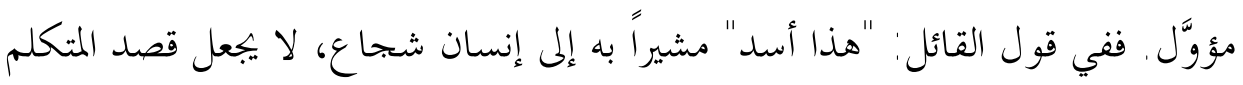

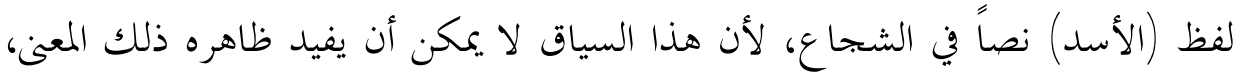

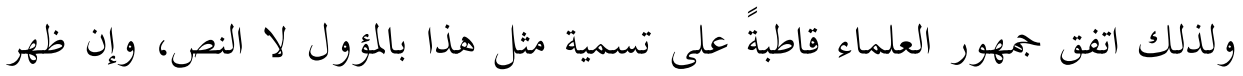

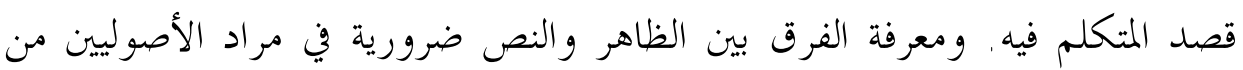

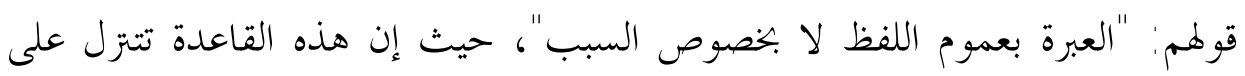

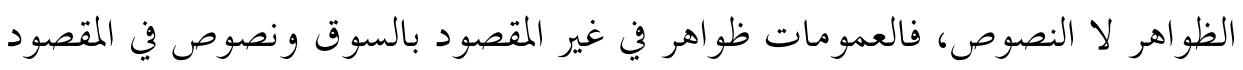

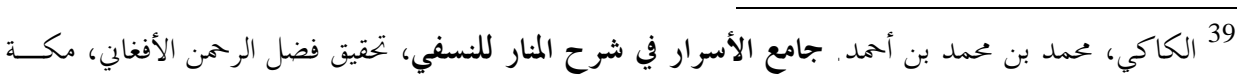

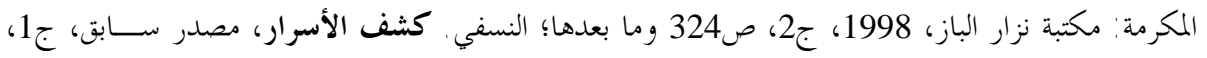

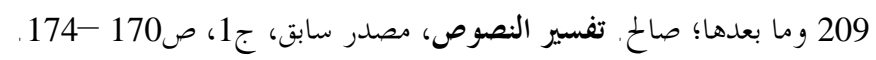

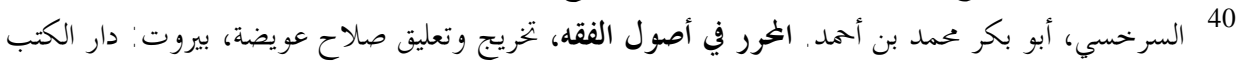

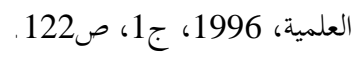


بالسوق. وقد صرح هذا السرخسي فذكر أن الخطاب يكون نصاً في السبب الذي

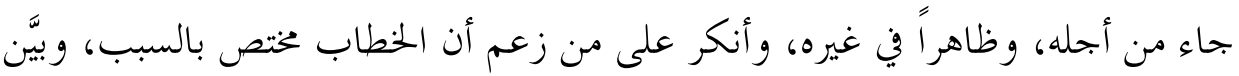

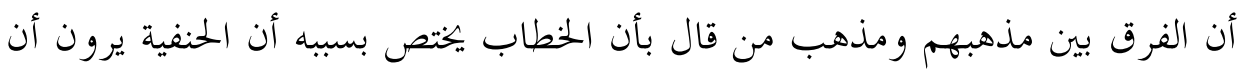
الخطاب نص في السبب، ظاهر باعتبار الصيغة في كل ما دخل تحت اللفظ، يقول:

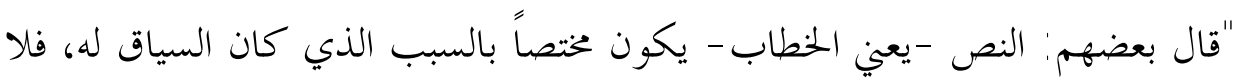

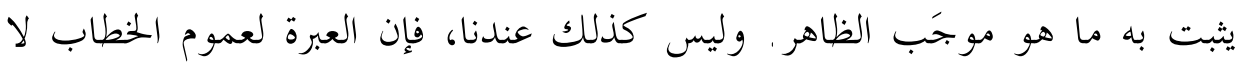

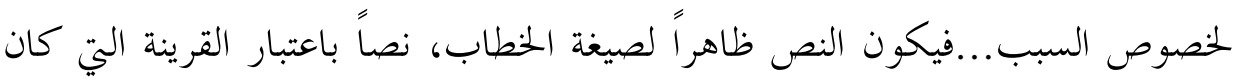

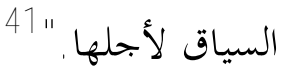

أما المفسر والمحكم فهما فوق النص ويشترط فيهما ما يشترط فيه. يقول النسفي

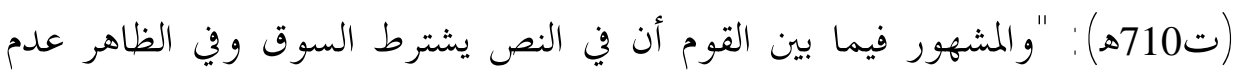

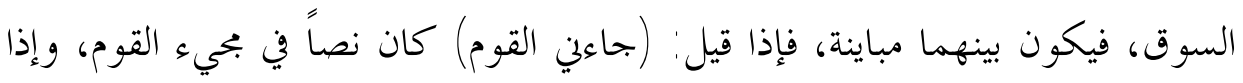

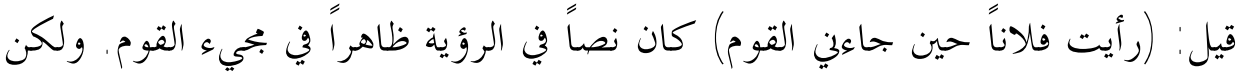

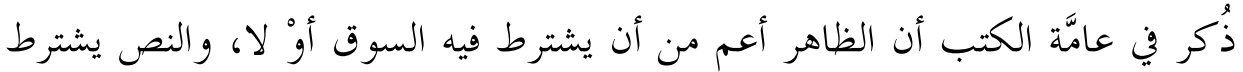

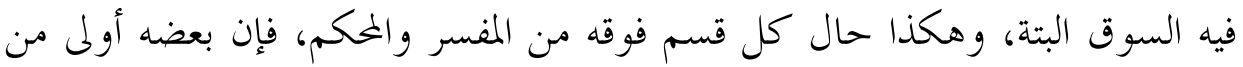

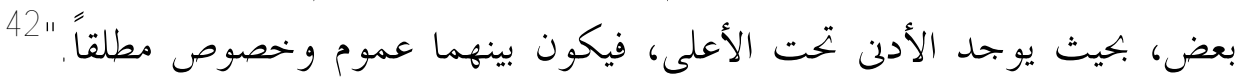

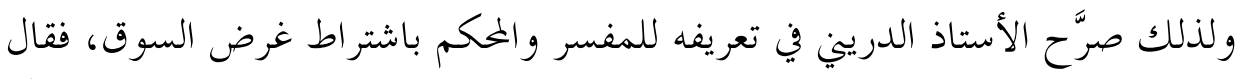

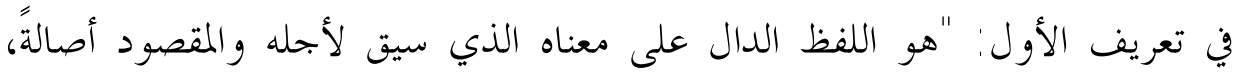

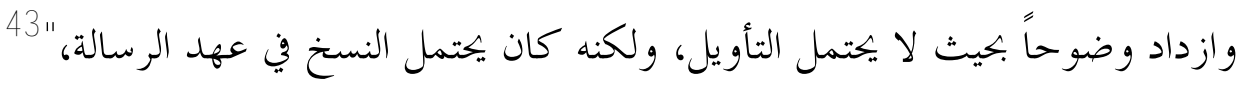

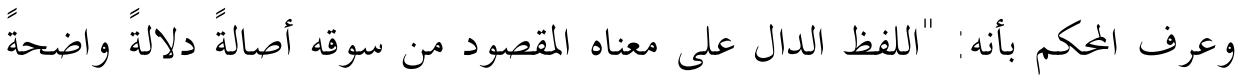

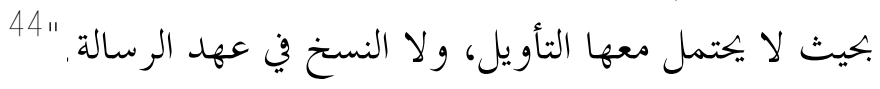

$$
\text { 41 النسفي. كشف السابق، ج1، صأسرار، مصدر سابق، ج122 ج123، ص206. }
$$

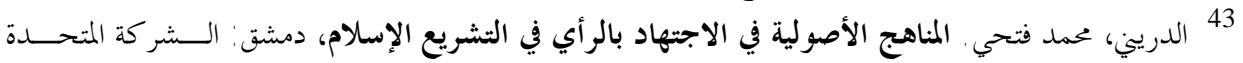

$$
44 \text { المصدر السابق، ص685، ص63. }
$$


50 إسلامية المعرفة، السنة الثانية عشرة، العدد 48، ربيع 1428هـ/2007م بخم الدين قادر كريم الزنكي

\section{2. أقسام النظم باعتبار مدى فهم مقصود الشارع من مبانيه:}

قسم الأحناف دلالة النظم باعتبار فهم مقصود الشارع من مبناه إلى ما يأتي: عبارة النص: وهي دلالة اللفظ على الحكم المسوق له الكالام أصالةً أو تبعاً بلا تأمّل. و هي كالنص في تقسيمهم السابق، حيث يشتر كان في أن كالً منهما يقصد

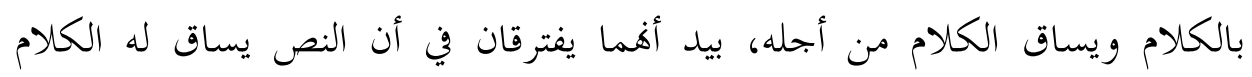

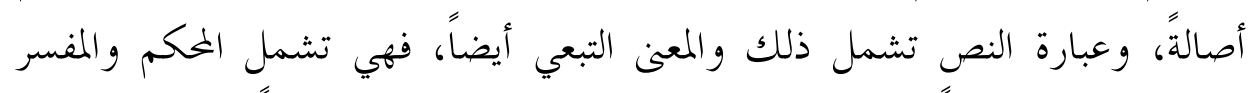

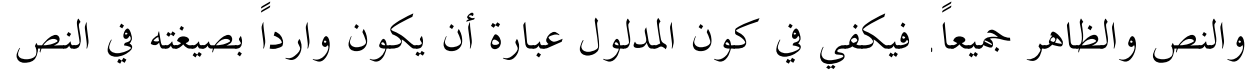

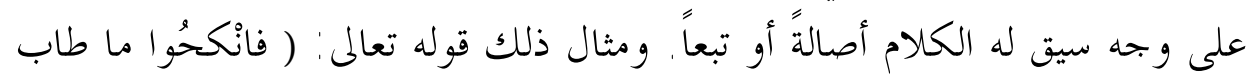

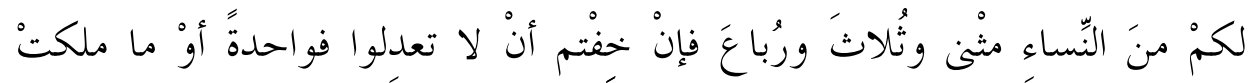

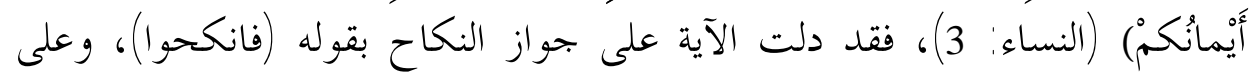

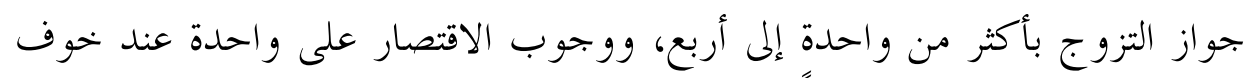

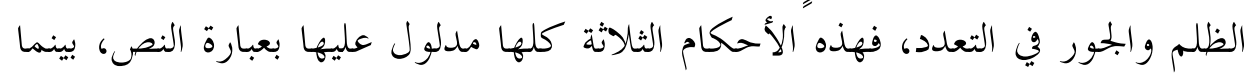
الحلكمان الأخيران فقط مدلول عليهما بالنص، ذلك أن المقصود من الآية ليس بيان

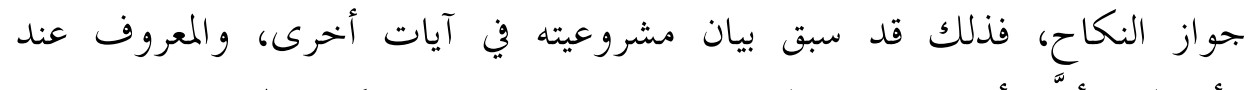

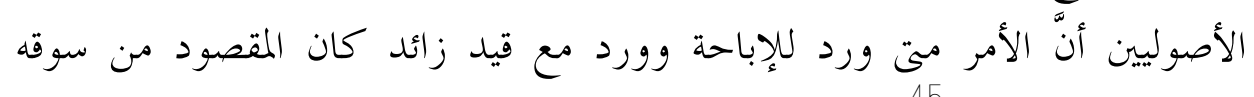
وجوبَ مراعاة القيد.

إشارة النص: وهي دلالة اللفظ على حكم لا يظهر من اللفظ ظهوراً أولياً، ولا

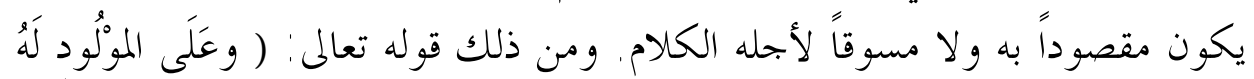

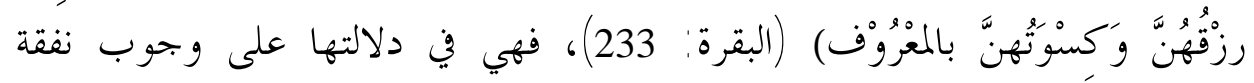

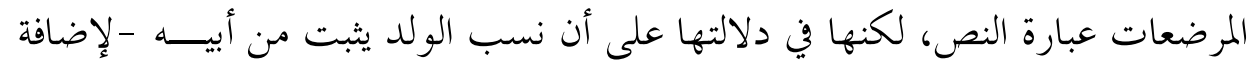

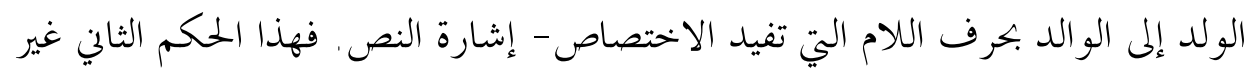
ظاهر من السياق كظهور الحكم الأول. 46

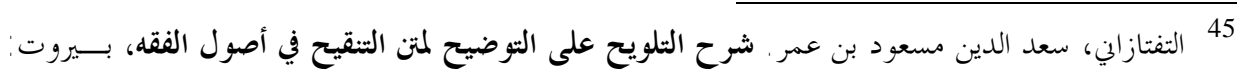

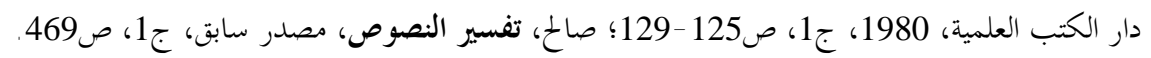

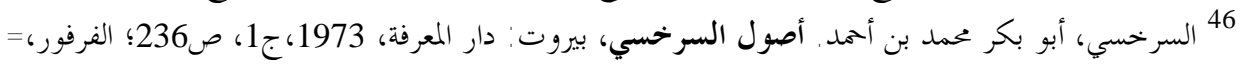


دلالة النص: وهي دلالة اللفظ على حكم الصورة المذكورة للصورة المسكوت عنها، لاشتراكهما في معنى (وصف) يعرف كل عارف باللغة أن ذلك المعنى هو علة

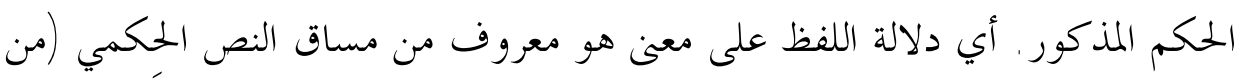

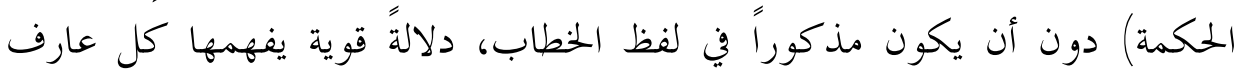

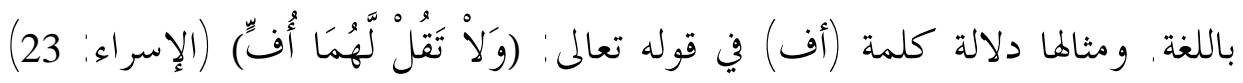

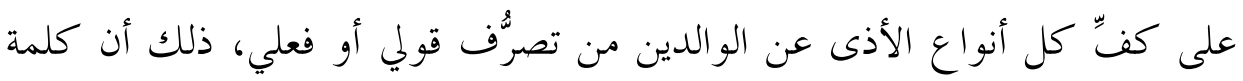
(أفّ) ليست اسماً، بل هو اسم فعل، وأسماء الأفعال ليست مقصودةً لأسمائها، بل

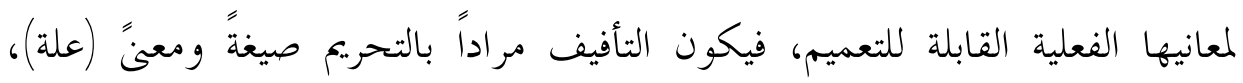

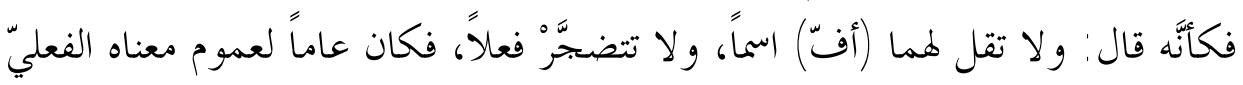

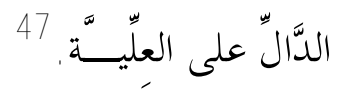

اقتضاء النص: وهو دلالة اللفظ على معنى خارجٍ عن منطوق الكلام يتوقف عليه

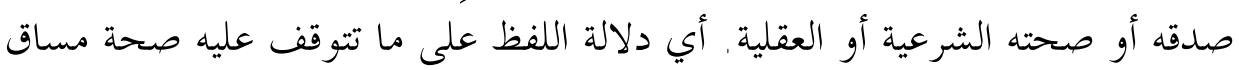

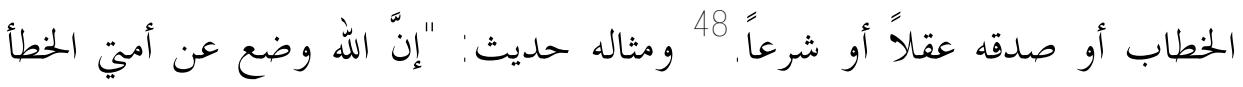
و النسيان،"49 فإن ظهور صدق الكالام متوقف على تقدير معنى، لأن آحاد الأمة لم

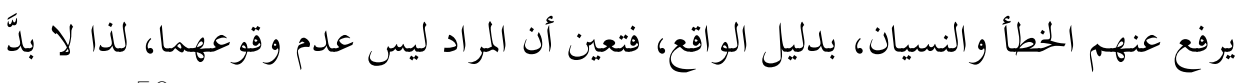
من تقدير محذوف بأن يقال: وُضع إتم الخطأ، أو وضع حكمهمها عن الأمة.

= ولي الدين محمد صالح. المذهَّب في أصول المذهب على المنتخب للإخسيكتي، دمشق: دار الفرفور، 1999،

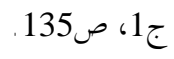

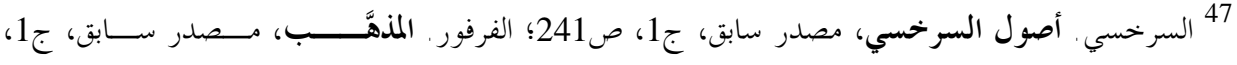

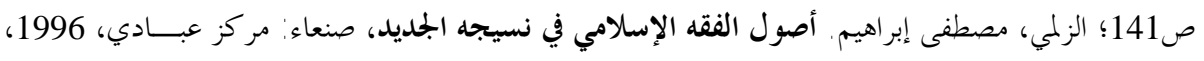
ص290 -291.

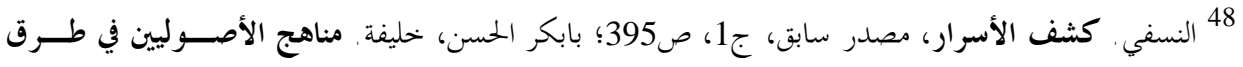

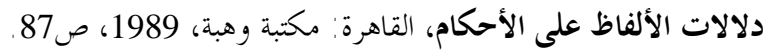

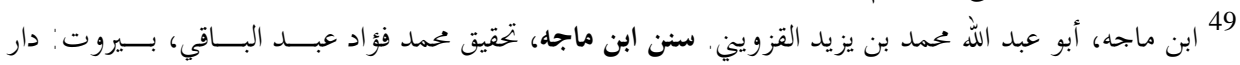

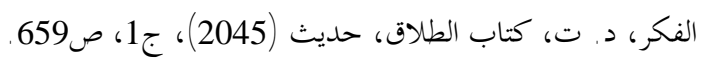

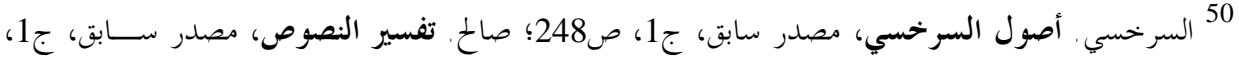


52 إسلامية المعرفة، السنة الثانية عشرة، العدد 48، ربيع 1428هـ/2007م بخم الدين قادر كريم الزنكي

ويتجلى في هذا التقسيم عنصر السياق بالإطلاق الثاني المرادف للمقصود، فعبارة

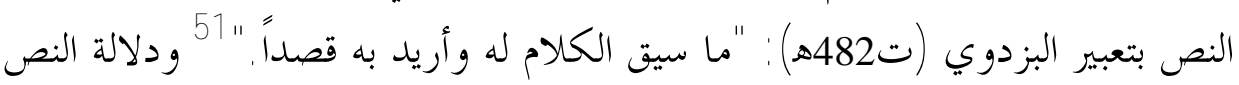
كما عرفها عبد العزيز البخاري (ت 730ه): "فهم غير المنطوق من المنطوق بسياق الكالام ومقصوده."52 أما اقتضاء النص فإن فلسفته تقوم في في أساسها الأصولي على ضرورة التوفيق بين مؤدى عبارة النص وما يقتضيه منطق الواقع أو منطق العقل و مقصد الشرع. 53 أما دلالة الإشارة فهي دلالة اللفظ على ما لا يظهر في السياق

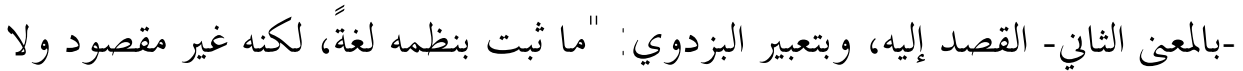

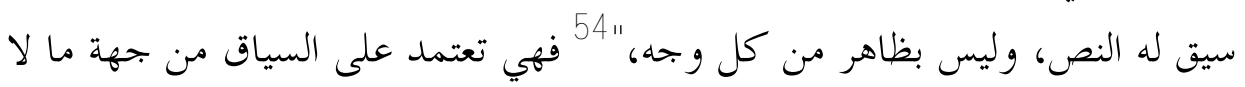
يظهر السياق فيه، أي من جانب عدم التأييد بغرض السَّوق من قبل المتكلم، و في هذا

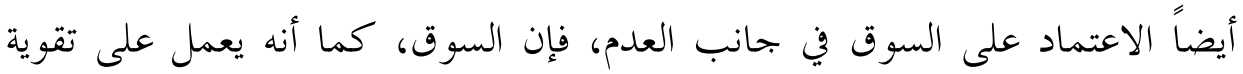
بعض المعاني، قد يعمل على توهين بعض المعاني أو جعلها معاني ثانويةً ولكن هل يعين هذا أن إشارة النص -عندهم - غير مقصودة للشارع مطلقاً، وأها لا مكان لها في السياق بإطلاقيه؟

يشير بعض الحنفية إلى أن الإشارة ثابتة بالنظم وأن ها حضوراً في مقال السياق، لكن ذلك الحضور لا يرقى في الظهور إلى درجة الكون مقصوداً من سوق الخطاب ظهوراً لغوياً أولياً، وذلك لعدم إسعاف قصد السوق في السور بذلك. وهذا يعني أن للمدلول

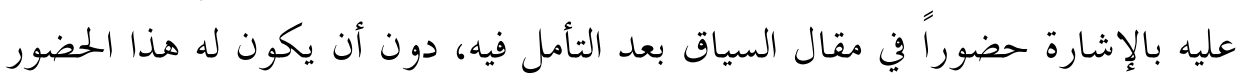

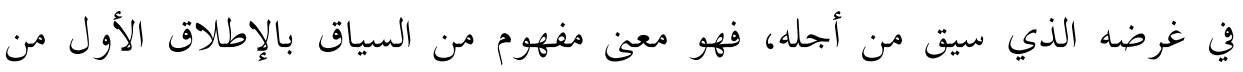
إطلاقي السياق، غير مفهوم منه بحسب الإطلاق الثاني الذي هو الغرض الذي من أجله

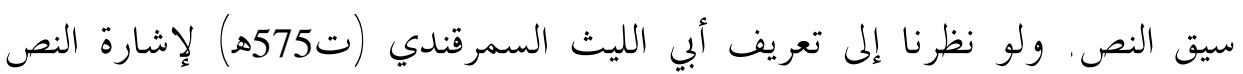
51 البزدوي، علي بن محمد. أصول البزدوي مع كثف الأسرار للبخاري، ضبط وتعليق محمد المعتــمم بــاللة

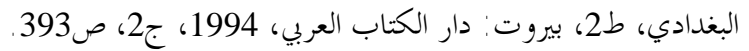

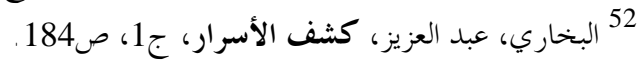

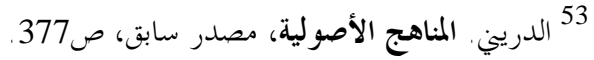

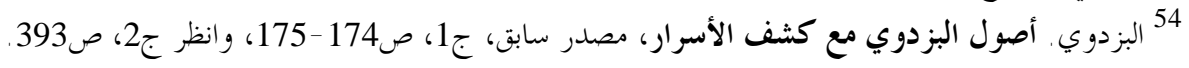




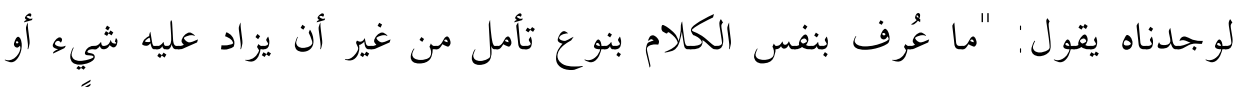

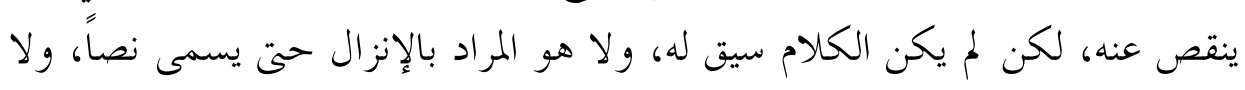

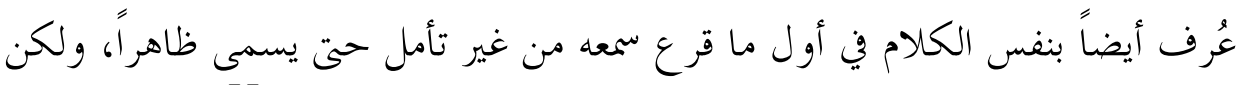

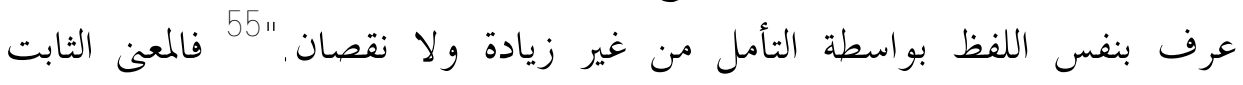

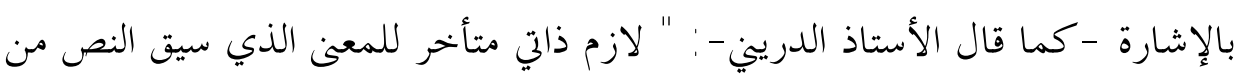

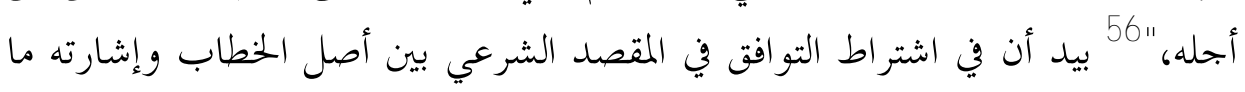

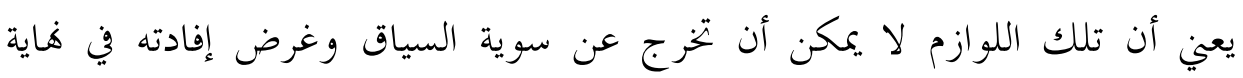
المطاف.

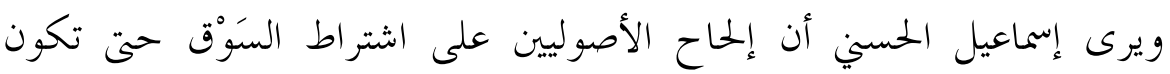

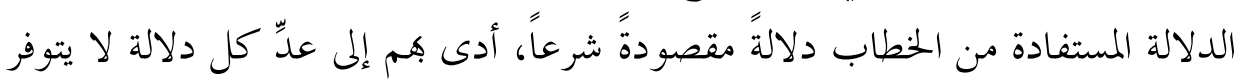
فيها هذا المكوِّن دلالةً غير مقصودة و إن استلزمها الخطاب.

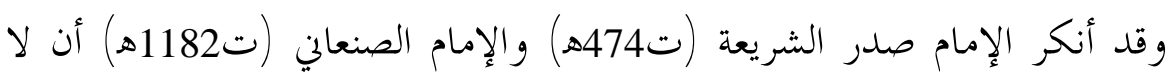

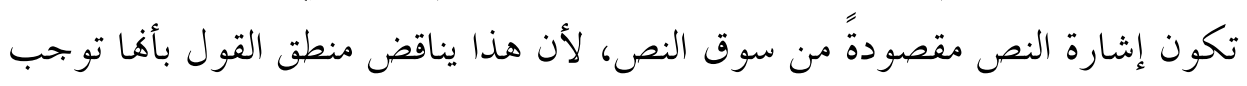

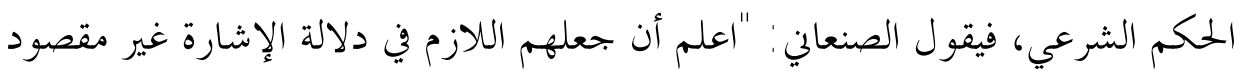

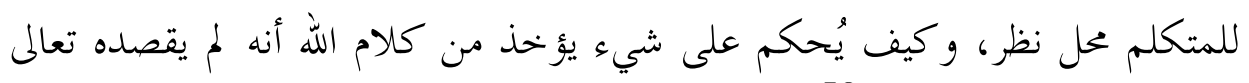

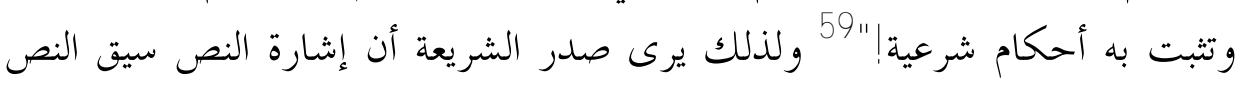

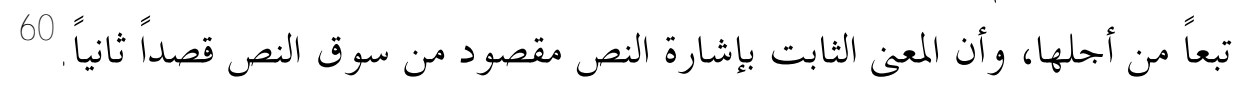

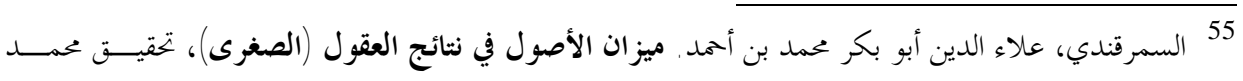

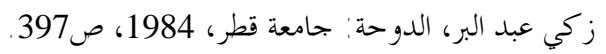

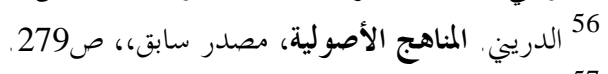

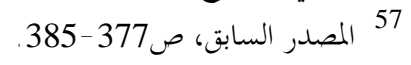

58 الحسني، إسماعيل. نظريَّة المقاصد عند الإمام محمَّد الطاهر بن عاشور، فيرجينيا: المعهد العلميّ للفكر الإسلاميّ،

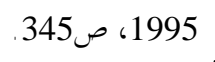

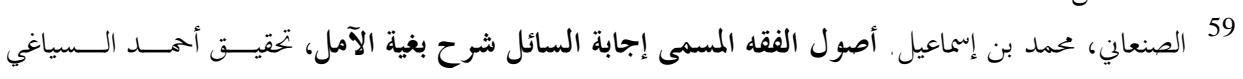

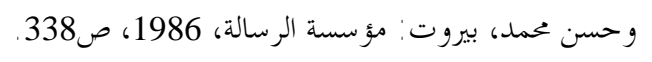

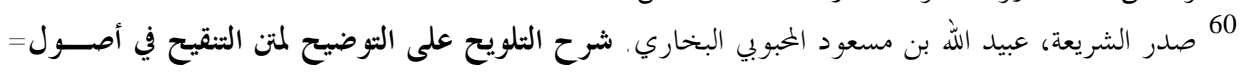


54 إسلامية المعرفة، السنة الثانية عشرة، العدد 48، ربيع 1428هـ/2007م بخم الدين قادر كريم الزنكي

إن استدلال الجمهور بإشارة النص يفهم منه أن سوق النص من أجل غرض، لا

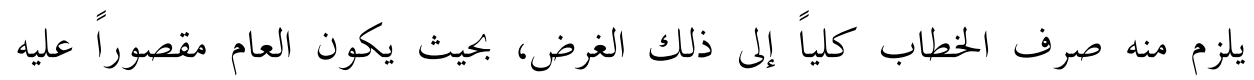

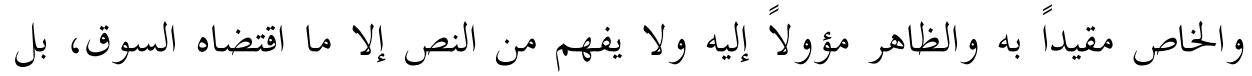
يصح إعمال الغرض في محل وموضع، وإعمال ظاهر الصيغة في غير ذلك المحل. وقد خالف الشاطبي في ذلك، وذهب إلى أن النص لا يمكن أن يستخرج منه معنى زائد عن ون الغرض الذي سيق له، وعليه فإنه ينفي أن تكون إشارة النص طريقاً لاستنباط الحلكم

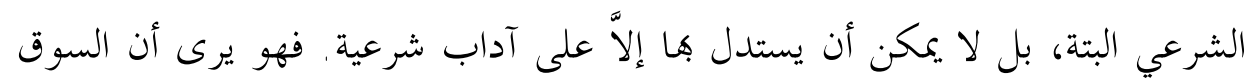

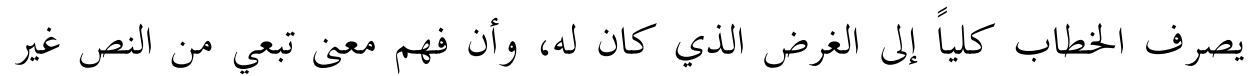
مسوق له الخطاب خطأ وتكلف، إلا أن يكون المعنى التابع مؤكداً للمقصود الأول وموثقاً لأصل الغرض.

و يستدل الشاطبي على مذهبه هذا بأدلة منها:

1. إن السياق إذا دلَّ على معنى” أصلي هو غرض الإفادة فيه وجب أن يكون كل

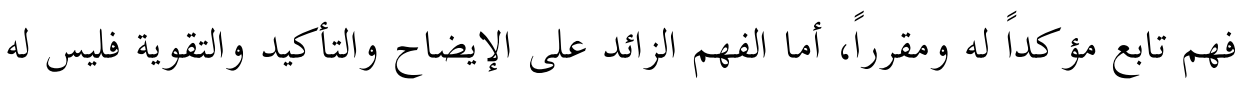
دور في فهم أصل الخطاب، و كل معنى لم يُعرف محله في مساق الخطاب و ولم يكن هو لهم

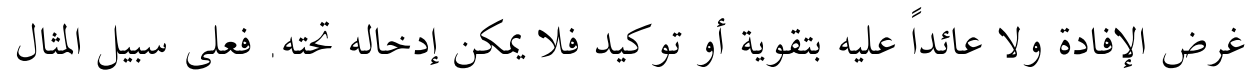
لو كان غرض سوق النص في قوله تعالى: (ذق إنَّك أنت العزيزُ الحكيمُ) (الدخان:

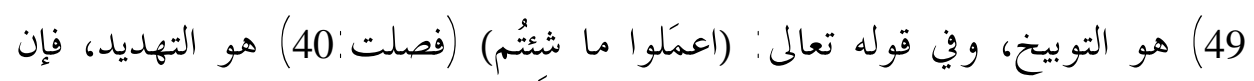
المعنى الأصلي للأمر في الآية الأولى هو الخزي والتوبيخ، وفي الثانية هو التهديد، وومعنى

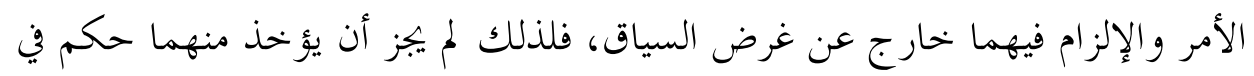
باب الأوامر، ولا يصح أن يؤخذ.

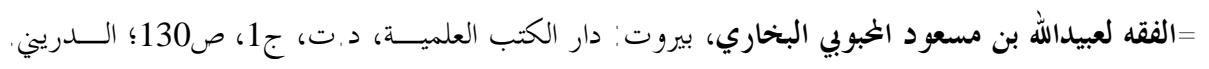

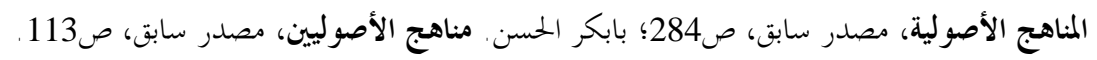

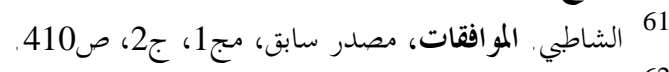

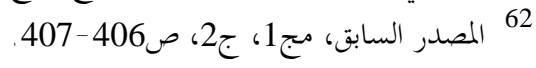


2. إن كان المعنى الذي لم يسق له الكلام مقصوداً من النص ويثبت به الحكم للزم

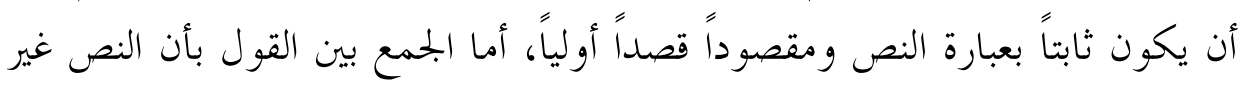

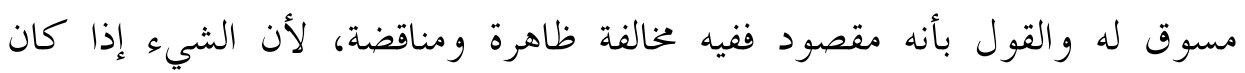
مقصوداً كان داخلاً في غرض الإفادة والسَّوق. 63

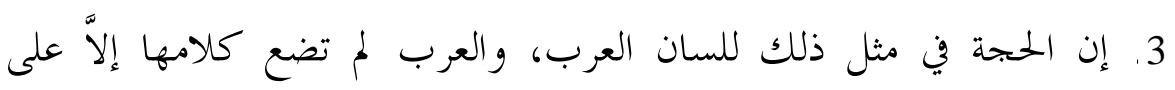

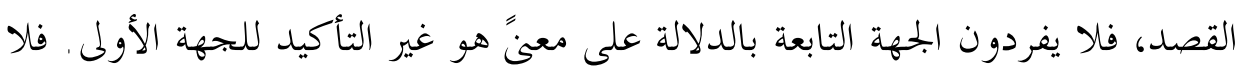

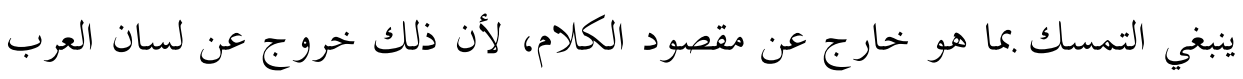

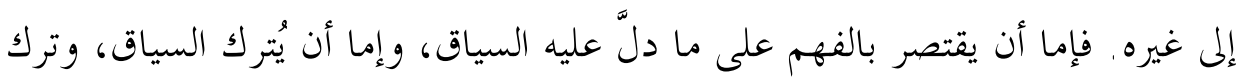

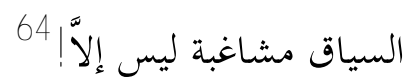

\section{والمخالفي الشاطبي أدلة عديدة، من أهها:}

(أ) إن الاستدلال على أحكام الشرع يكون من جهة لسان العرب، والعرب تفهم

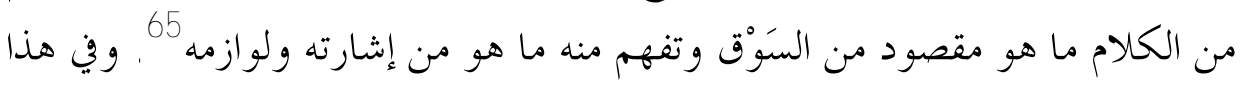

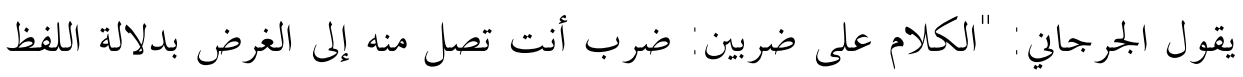

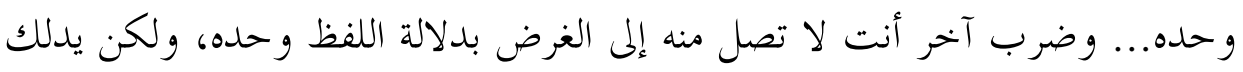

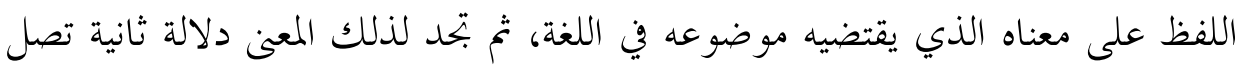

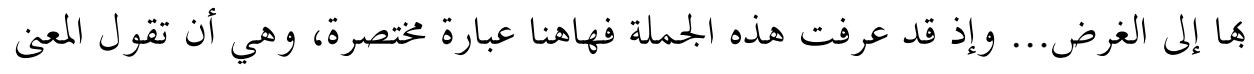

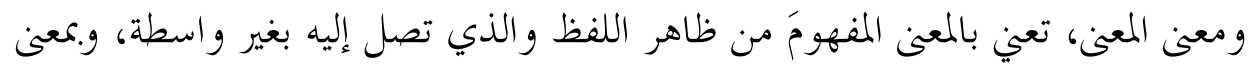

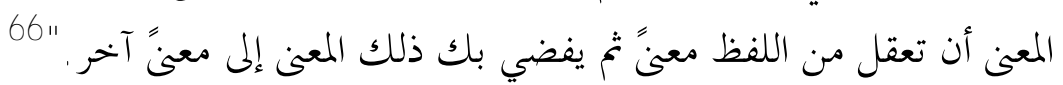

(ب) وأقوى دليل تمسك به الجمهور هو أن الغرض الذي سيق من أجله الخطاب

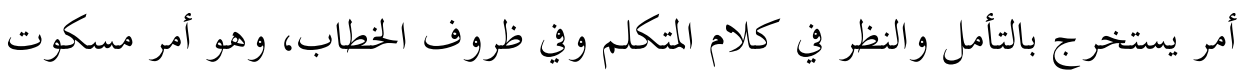

$$
\begin{aligned}
& 63 \text { المصدر السابق، مج1، ج2، ص408. } \\
& 64 \text { المصدر السابق، مج1، المبان، ج2، ص2، ص408 -409، }
\end{aligned}
$$

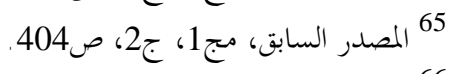

$$
\begin{aligned}
& 66 \text { الجرجاني. دلائل الإعجاز، مصدر سابق، صالي، 1960، ص174 -175. }
\end{aligned}
$$


56 إسلامية المعرفة، السنة الثانية عشرة، العدد 48، ربيع 1428هـ/2007م بخم الدين قادر كريم الزنكي

عنه. ويعني هذا أن دلالة السوق في نفسها دلالة ذوقية، ولذلك تستوي مع الدلالة الذوقية التي تستخرج من إشارة النص بالتأمل. 67 و خحلافاً للشاطبي، يرى الشيخ ابن عاشور (ت1393هـ) أن كلَّ معنى أمكن فهمه من النص الشرعي في حدود ما تسمح به تراكيبه الجحارية على فصيح الكلام فهو مراد

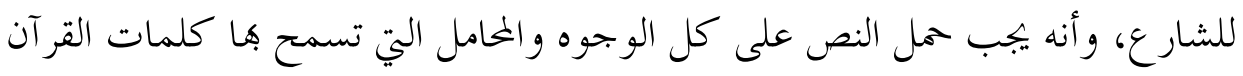
وتراكيبه وإعرابه ودلالته ما لم يُفض ذلك إلى خلاف المقصود من السياق . ويستشهد

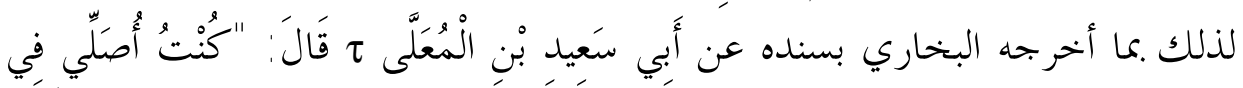

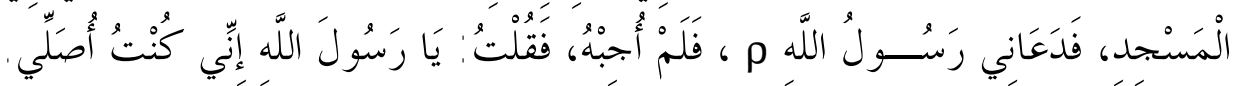

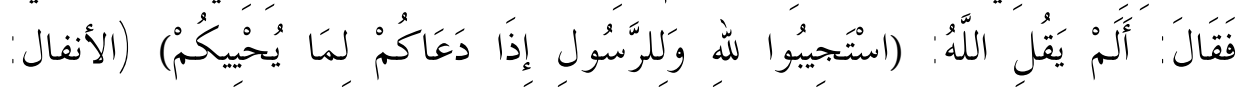

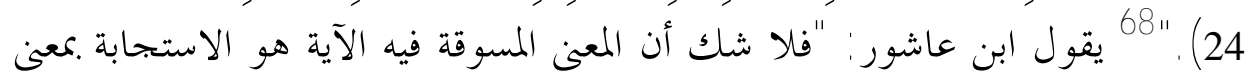

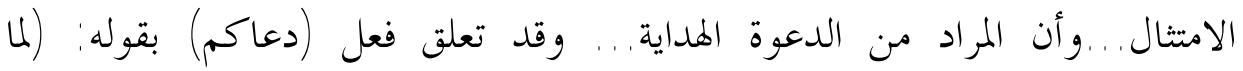

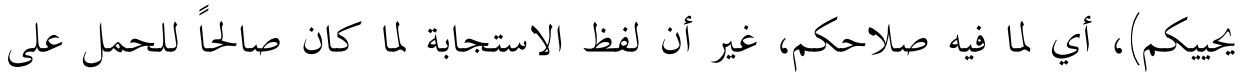

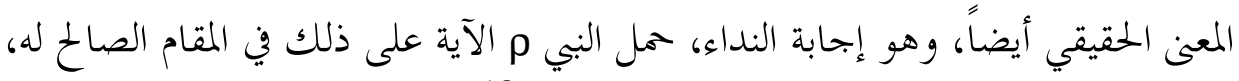

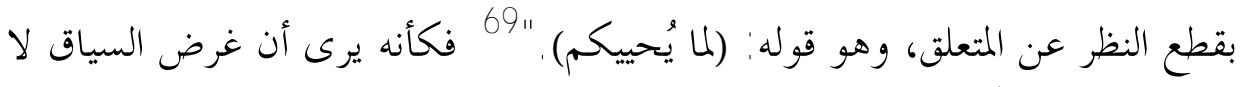

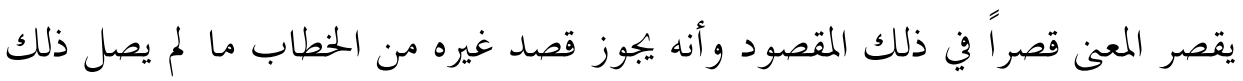
المعنى إلى مخالفة غرض السياق. ولذلك خلص إلى أن الذي يجب إعب اعتماده هو حمل المشترك على ما يحتمله من المعاني، سواء في ذلك اللفظ المفرد، و التركيب المشترك بين إكتين

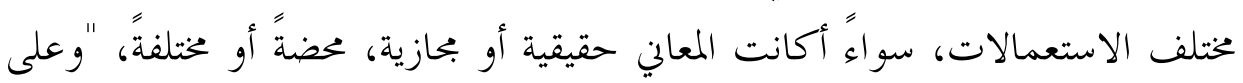
هذا القانون يكون طريق الجمع بين المعاني التي يذكرها المفسرون، أو ترجيح بعضها

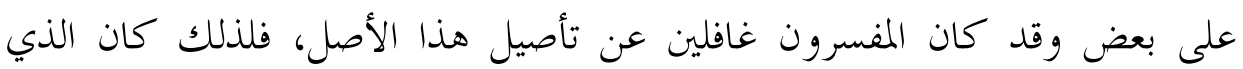

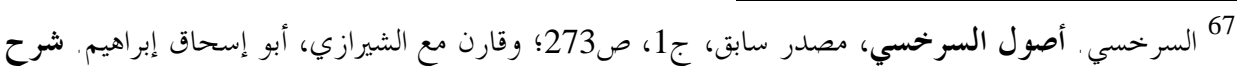

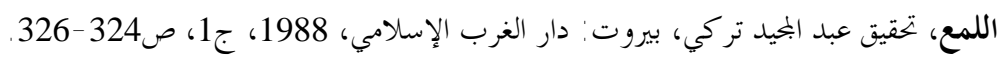

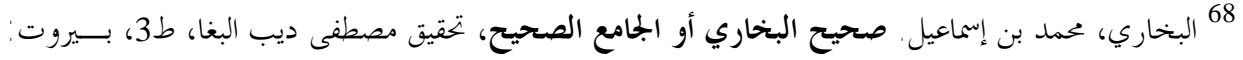

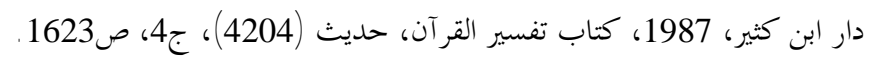

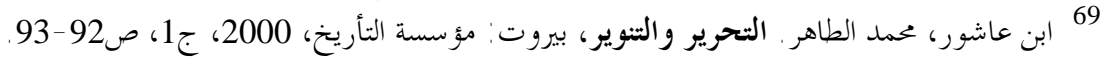


يرجح معنى من المعاني التي يحتملها لفظ آية من القرآن يجعل غير ذلك المعنى ملغى".

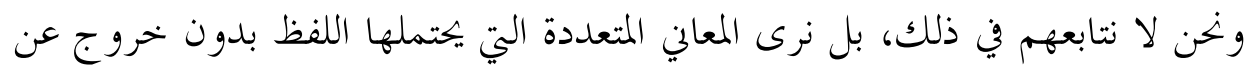

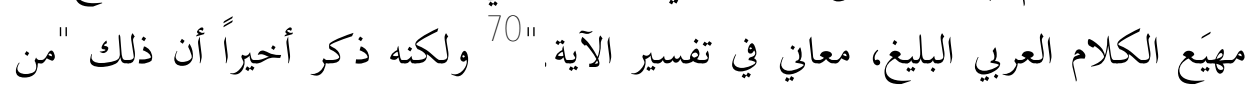

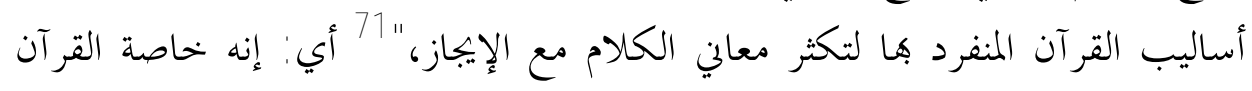
وحده وليس ذلك لكلام العرب على وجه العموم.

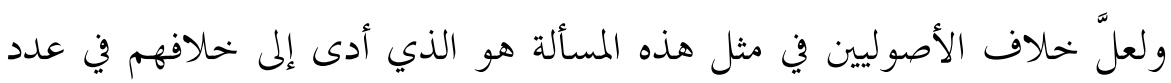

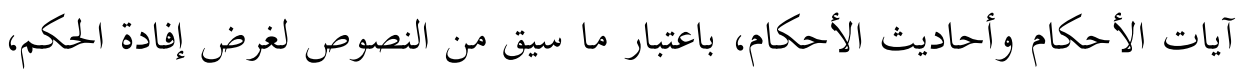

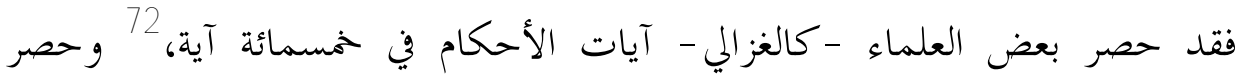

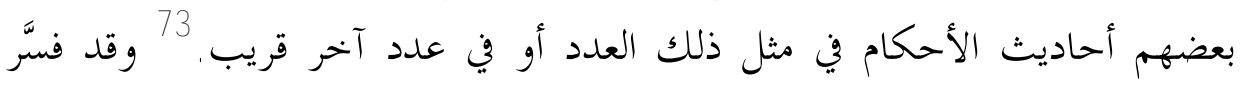

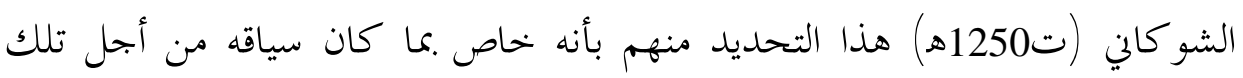

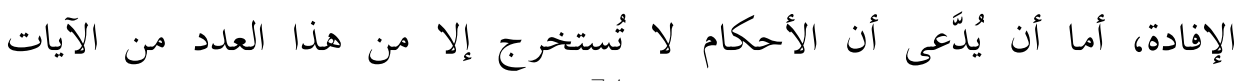
والأحاديث فذلك ادعاء غير صحيح عنده. 74

\section{ثالثاً: التصور الأصولي لأحكام السياق وأثره في فهم المقاصد وتفسيرها}

لقد صاغ الأصوليون تصورات عدة للسياق وأحكامه تعود بالأثر على طبيعة

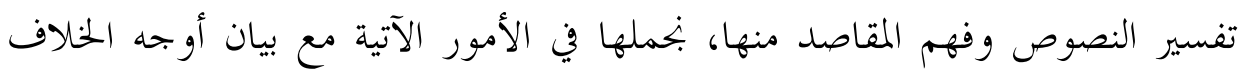

$$
\begin{aligned}
& \text { المصدر السابق، ج1، ص97 - } 98 \text { - } 98 . \\
& 71 \text { المصدر السابق، ج1، ص123، صلمد، نقل بتصرف. }
\end{aligned}
$$

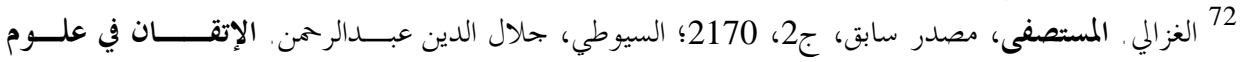

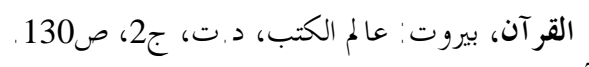

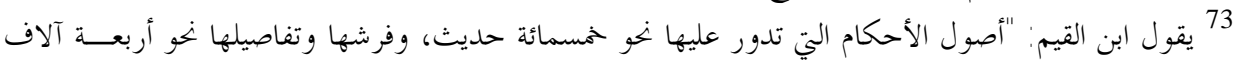

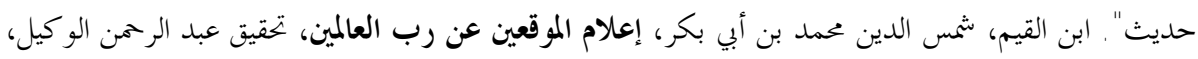

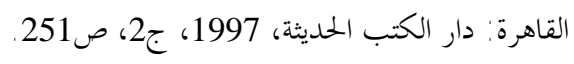

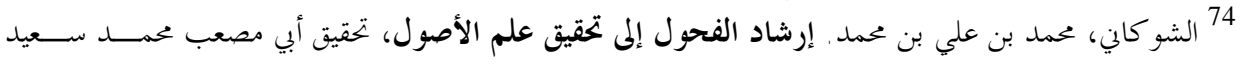

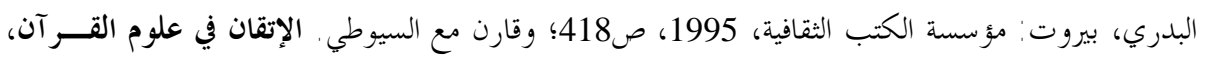

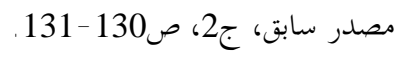


و الوفاق فيها مما يرجع بالأثر على فهم مقصود الشارع:

\section{1ـ تصوّرهم دور السياق الوظيفي:}

اختلف العلماء في وظيفة السياق هل هي تأسيس المعنى أو الإرشاد إليه فحسب؟

وذلك بناء" على الاختلاف في دور القرينة الاستعمالية على المعنى ومدى صدق الفكرة

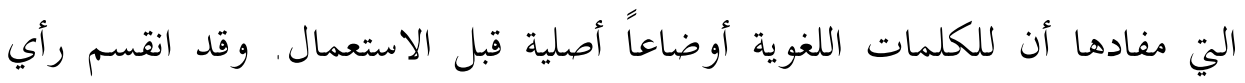
العلماء في هذا إلى مذهبين اثنين؛ مذهب الجمهور القائلين بالوضع، ومذهب ابن تيمية

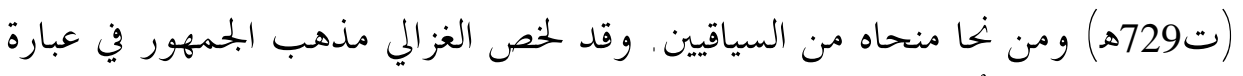

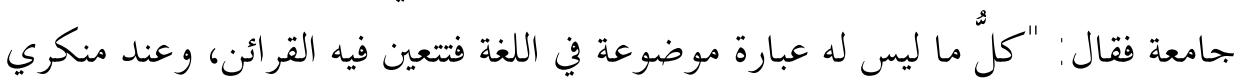

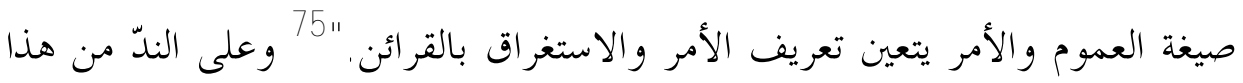
التوجه يقف الإمام ابن تيمية الحراني، فهو يرى أن معنى المفردة لا يتعين إلا بالقرائن وأن لا وضع سابق للمفردة اللغوية، وما يتبادر إلى الذهن عند إطلاق اللفظة من معنى لئن إنما هو باعتبار عرف الاستعمال الشائع، وهو قيد وقرينة حالية. فعنده يؤسس السياق

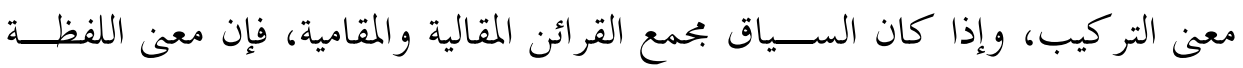

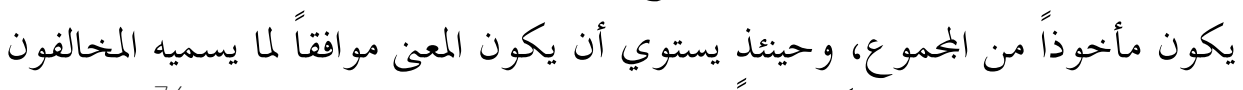

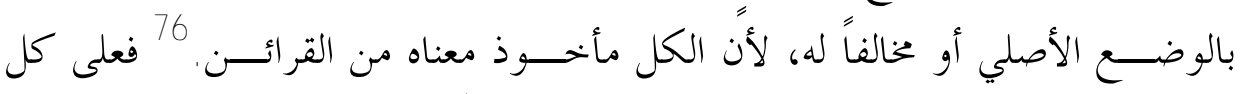

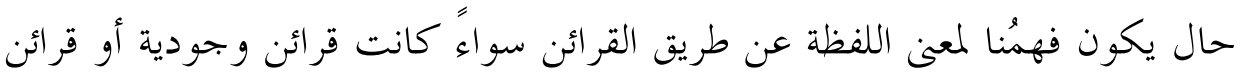
عدمية، 77 ومنه نفهم أن ابن تيمية يرى أن استحضار القرائن متعين في تفسير كل لفظ لفظ

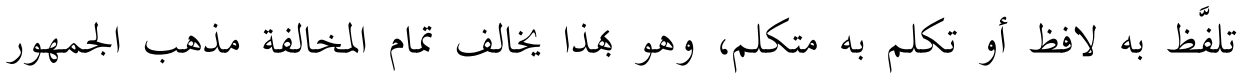

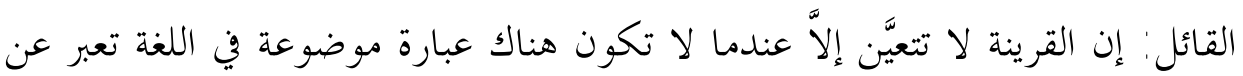
ذلك المعنى أو تكون هناك عبارة موضوعة، لكن يستخدم غيرها. ويمكن أن نلخص إنص الفرق بين الوجهتين بأن الجمهور يقصرون وظيفة القرينة السياقية على الإرشاد، بينما

$$
\text { 75 الغزالي. المستصفى، مصدر سابق، ج1، ص230. }
$$

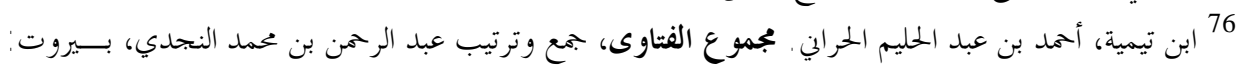

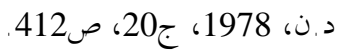

$$
\begin{aligned}
& 77 \text { المصدر السابق، ج20، ص2078، ص412 -413. }
\end{aligned}
$$


يصفها ابن تيمية بأها تأسيسية لا معنى للفظة دوها. 78

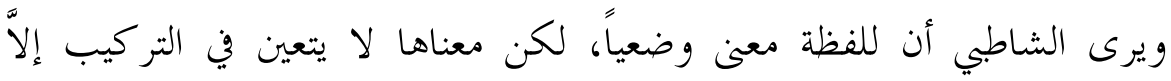

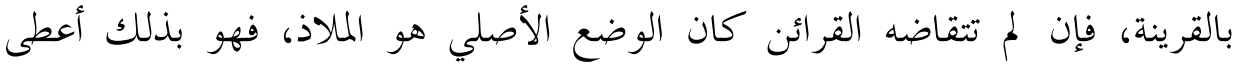

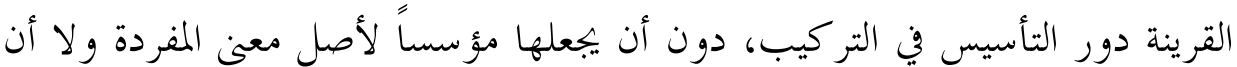
ينفي الأوضاع الأصلية للكلمات. 79 وكان من أثر هذا الحخلاف لوظيفة السياق في تعيين المقصود من الخطاب أفم اختلفو إي البحال التشريعي أي المعاني هي الأصل في تفسير مقصود الشارع، أهو المعنى

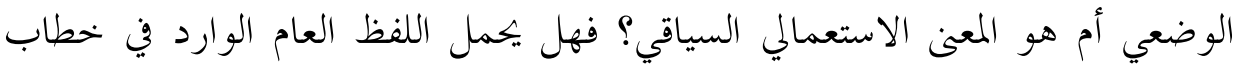

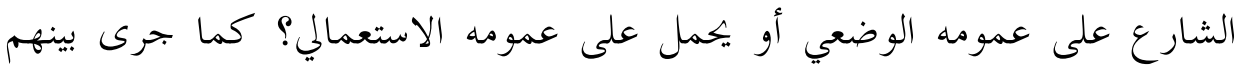

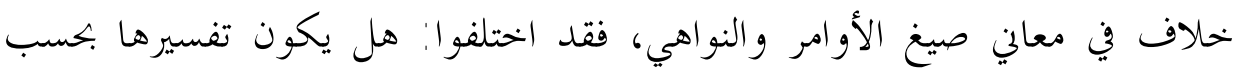

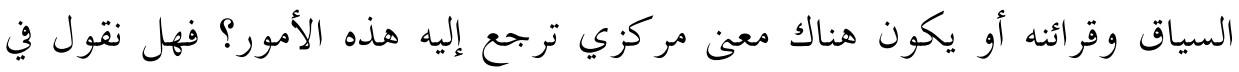

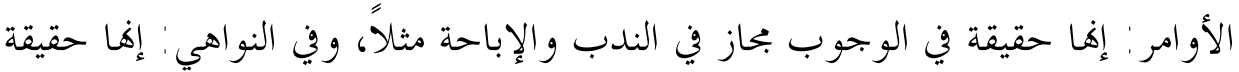
في التحريم بحاز في الكراهة، وفي صيغ العموم: إذا حقيقة في الاستغراق بحاز في إرادة

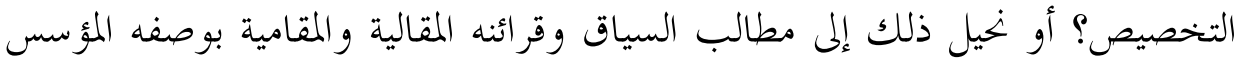

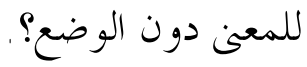

وقد بحث الإمام الشاطبي في أدلة الفريقين وما ينجم عن المذهبين من نتائج، فعضَّ

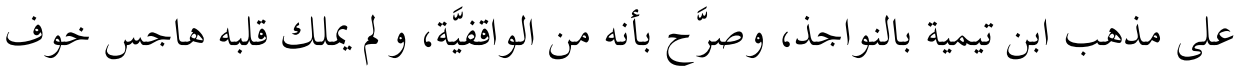

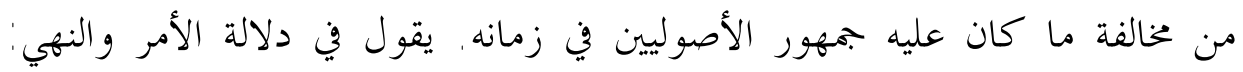

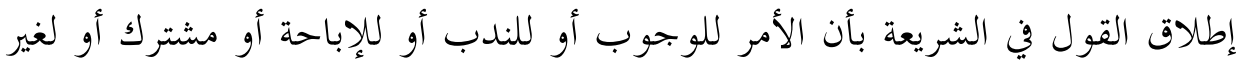

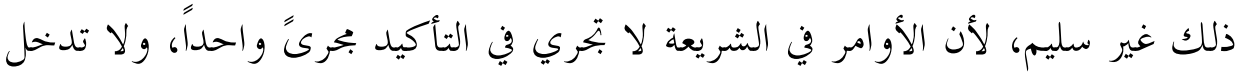

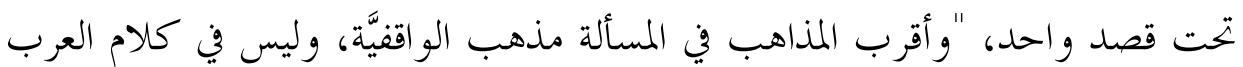

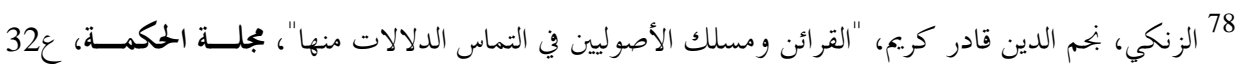

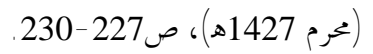
79 الشاطبي، الموافقات، مصدر سابق، مج2، ج3، ص230 ص239 -245. 
60 إسلامية المعرفة، السنة الثانية عشرة، العدد 48، ربيع 1428هـ/2007م بخم الدين قادر كريم الزنكي

ما يُرشد إلى اعتبار جهة من تلك الجهات دون صاحبتها."80

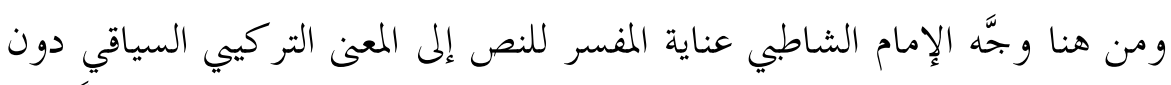

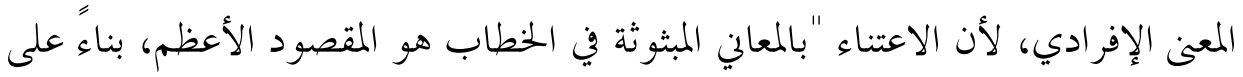

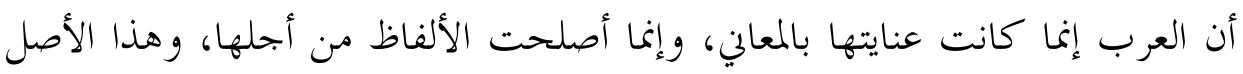

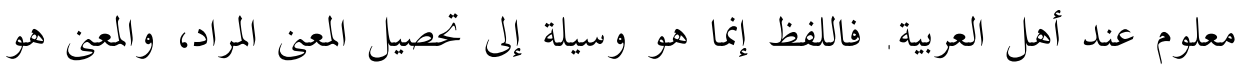

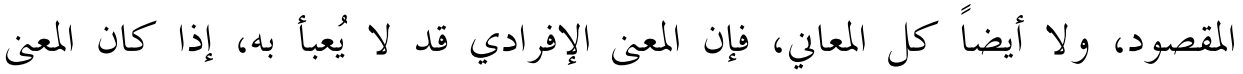

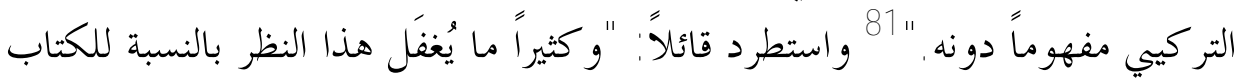

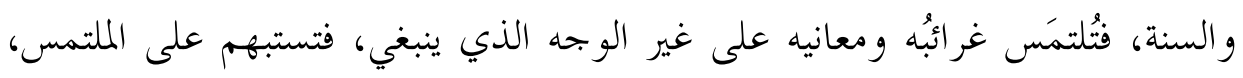

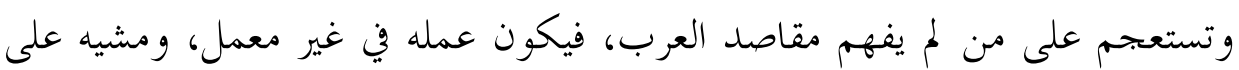
غير طريق."

\section{2. تصورهم لمرجع الدلالة السياقية:}

يظهر من عبارات بعض العلماء أن دلالة السياق .معنى الغرض الذي سيق له النص

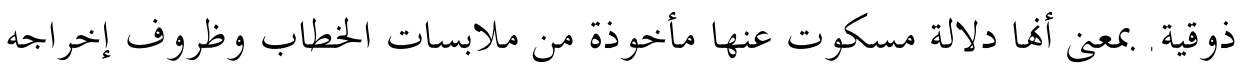

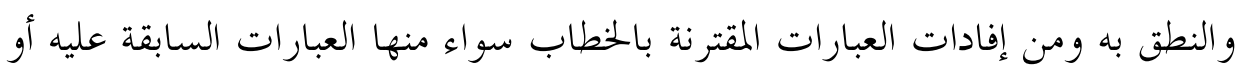
اللاحقة له. وقد صرح هذا الحكم كل من الإمام ابن دقيق العيد والإمام الصنعاني.

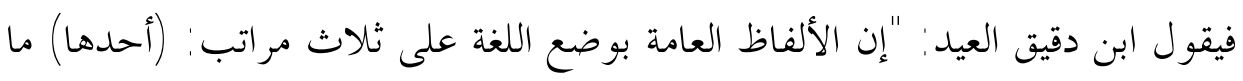

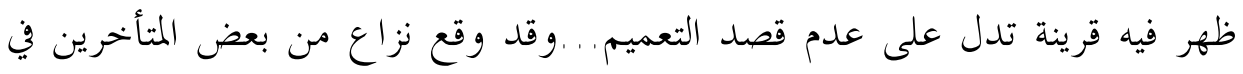

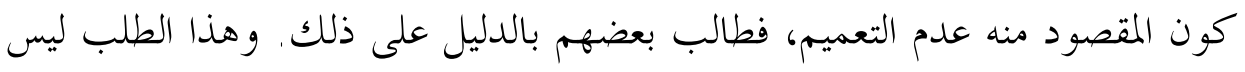
بجيد، لأن هذا أمر يُعرف من سياق الكاملام، ودلالة السياق لا يقام عليها دليل. بكان.

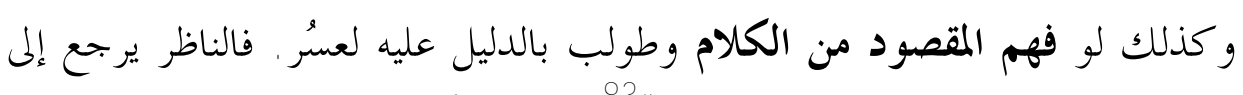

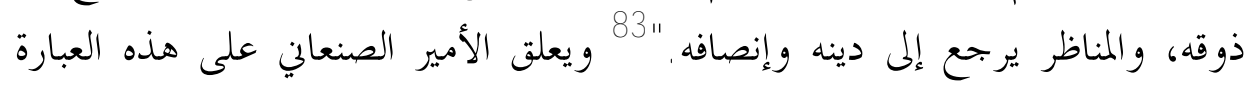

$$
\begin{aligned}
& \text { 80 المصدر السابق، مج2، ج3، ص187 -188. }
\end{aligned}
$$

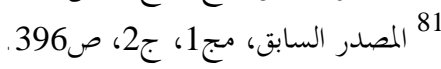

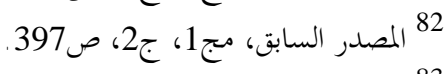

83 ابن دقيق العيد. إحكام الأحكام شرح عمدة الأحكام، مصدر سابق، مج1، ج2، ص145 -146. 
بقوله: "وذلك لأن دلالة السياق ذوقية، والأذواق تختلف، فربَّ شخص يدرك دلالة

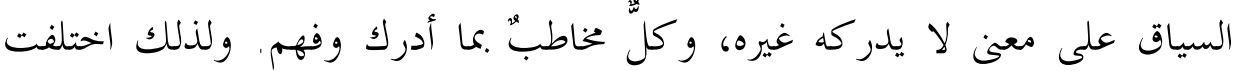

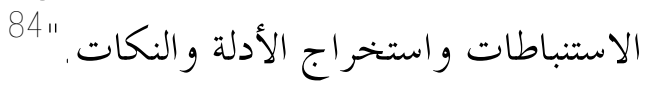

ويفهم من هذه العبارات أنه لا ينبغي أن يطالب المتفهم للنص بالدليل على ما فهمه

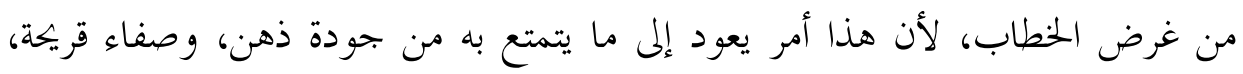

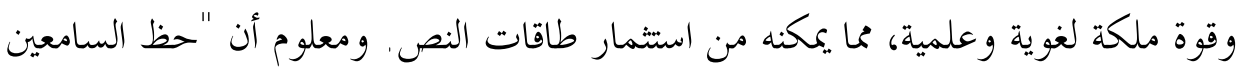

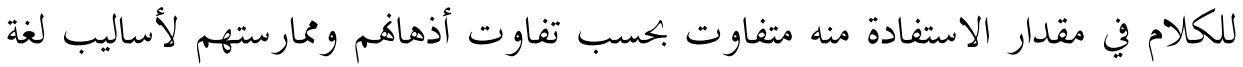

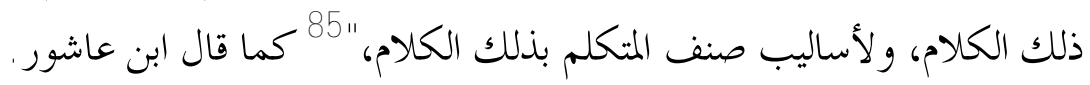
فما ذكره الإمام ابن دقيق العيد وتبعه فيه الصنعاني محمول على السياق الذي بمعنى

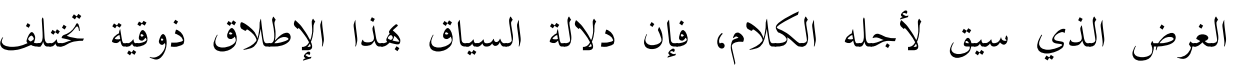
باختلاف الأذواق إلى حد كبير، وذلك لأن الغرض الذي سيق له النه النص يُستخرج

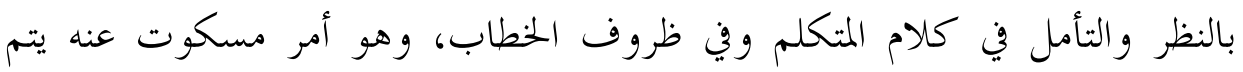

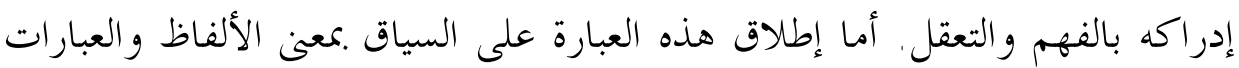

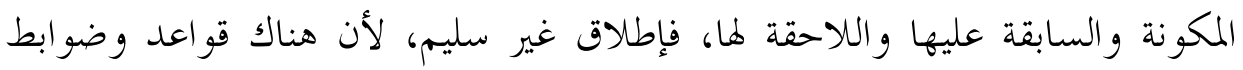

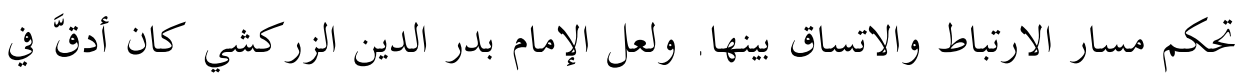

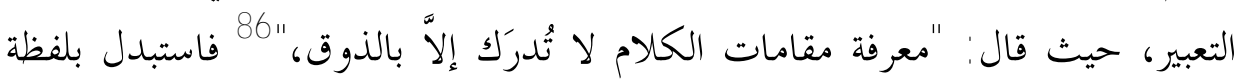

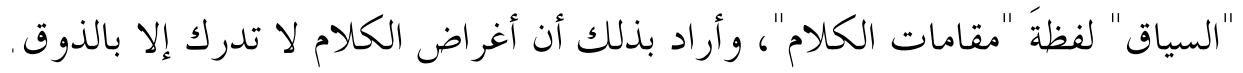

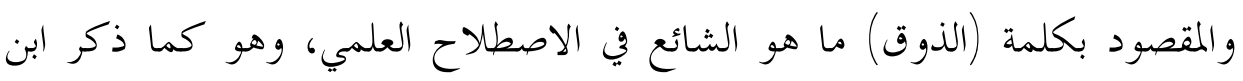

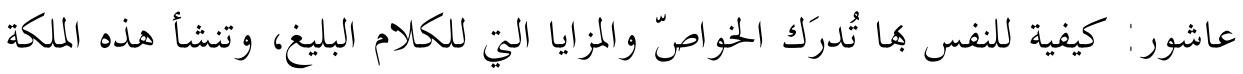

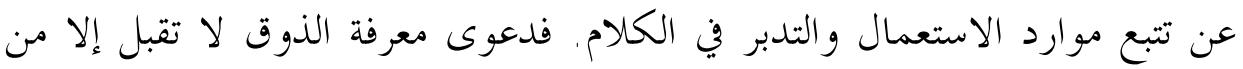

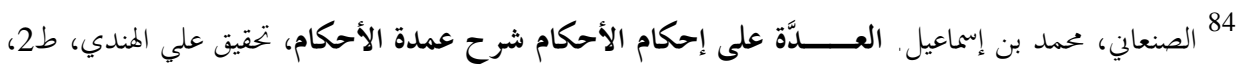

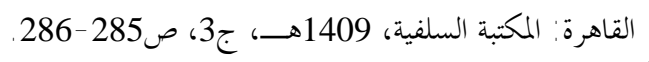

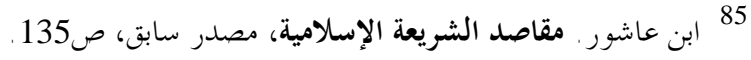

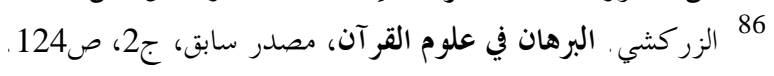


62 إسلامية المعرفة، السنة الثانية عشرة، العدد 48، ربيع 1428هـ/2007م بخم الدين قادر كريع الزنكي

87

الخاصة، وهو يضعف ويقوى بحسب المراس و المران و التدبر.

و بالتأمل في عبارة ابن دقيق العيد نفهم أن المتمسك بسياق الخطاب وغرض إفادته والمتمسك .كمغى الكالام ومقصوده لا يطالب بالدليل الزائد على أصل الذوق التفسيري المعتبر، وأن مرجع الناظر إلى ذوقه في فهم الخطاب وغرضه، ومرجع المناظر إلى دينه و إنصافه.

و كان من آثار هذا التصور أن اختلف الأصوليون في التزام التخصيص بغرض

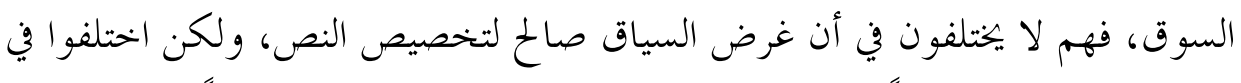

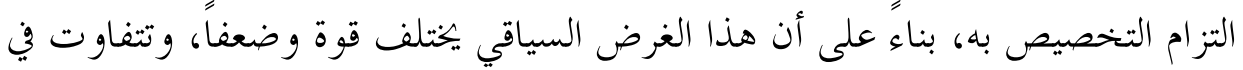

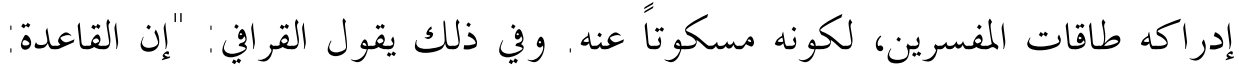

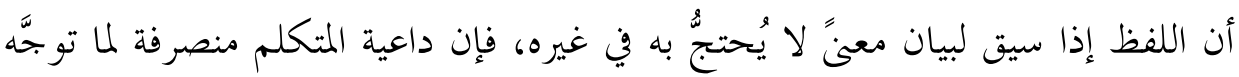

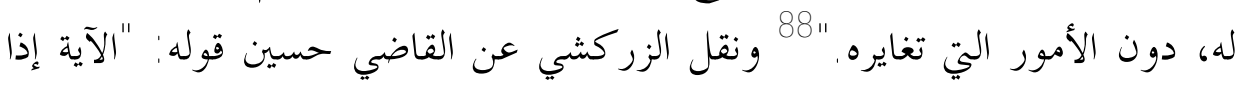

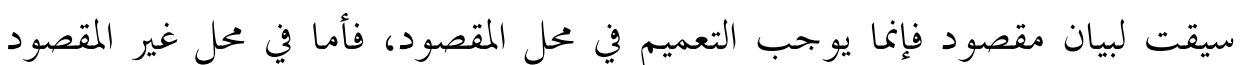

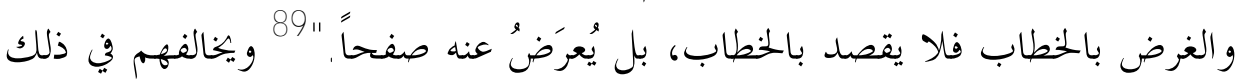

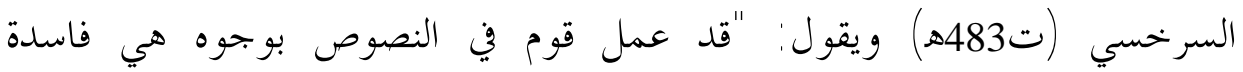

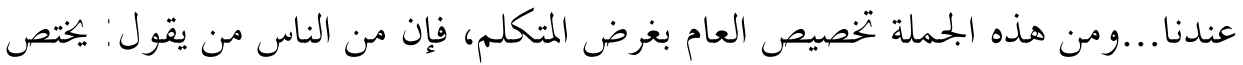
الكالام بما يُعلم من غرض المتكلم، لأنه يظهر بكلامه غرضه، فيجب بن بناء كلامه في

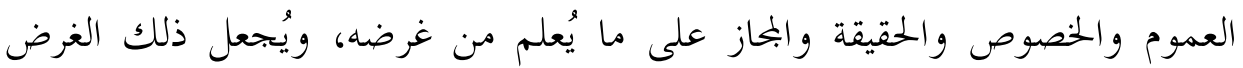

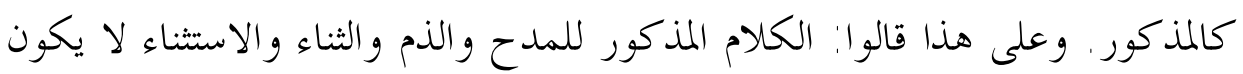
له عموم، لأنَّا نعلم أنه لم يكن غرضى هرو المتكلم به العموم. وعندنا هذا فاسد، لأنه ترك

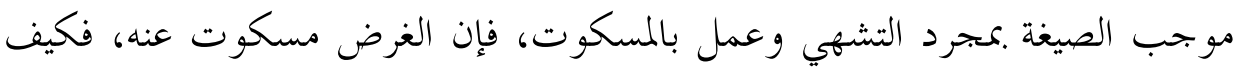

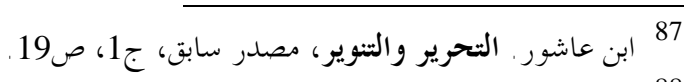

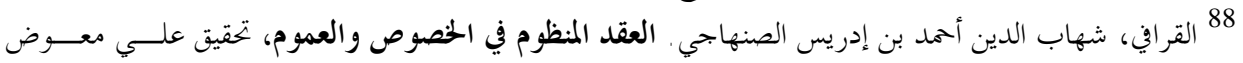

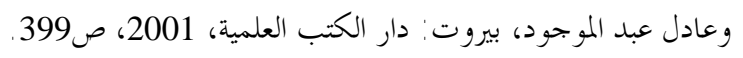

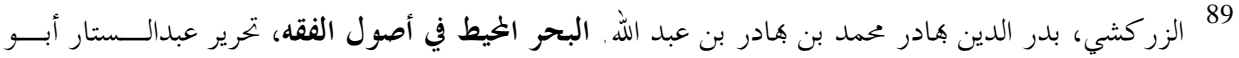

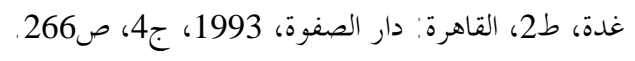




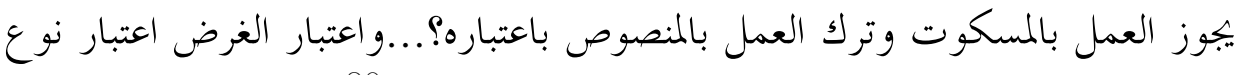

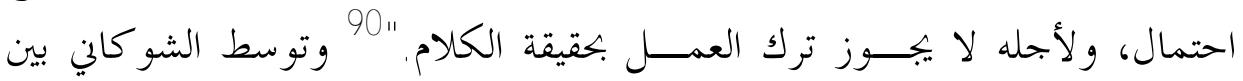

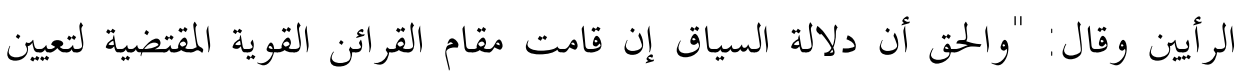

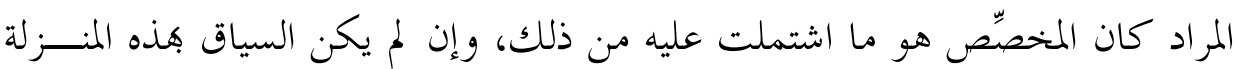
ولا أفاد هذا المفاد فليس بمخصصِص."

\section{3. تصورهم لامتداد الدلالة السياقية:}

يرى جمهور الأصوليين أن امتداد السياق حصر بالجملة ذات الإفادة. فإذا تمت الجملة واستقلت بالإفادة انتهى عندها امتداد السياق، فلا تتعدى إليها دلالة النظم

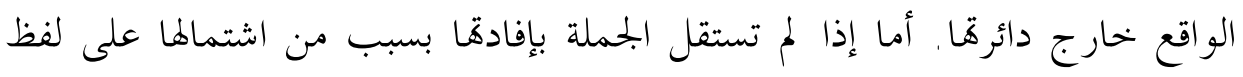

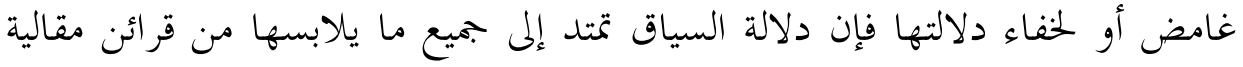
ومقامية تحتف ذلك الخطاب. وقد حملهم على هذا سبب موضوعي يتعلق بطبيعة نظم

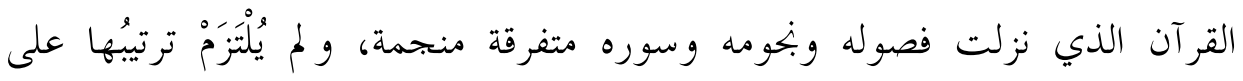
حسب تعاقبها الزماني، الأمر الذي يجعل التزام ظاهر النظم فيه وتسريب الدلالات

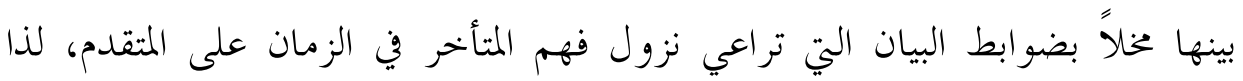

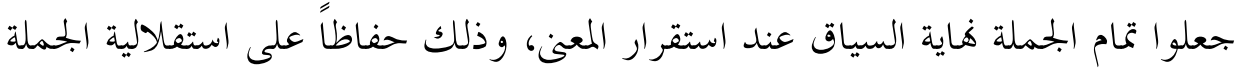

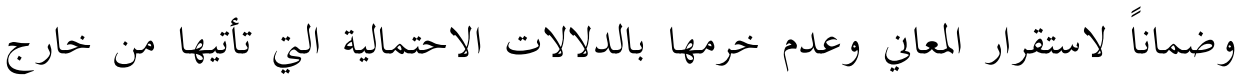

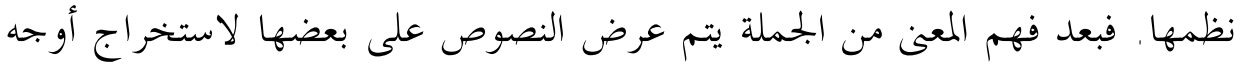

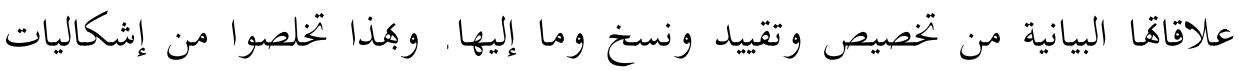
النظم المعروفة.

$$
\begin{aligned}
& \text { 90 السرخسي. أصول السرخسي، مصدر سابق، ج1، ص273. }
\end{aligned}
$$

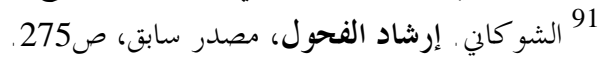

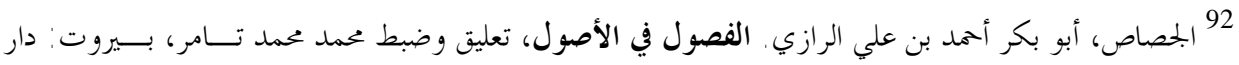

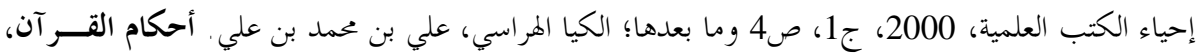

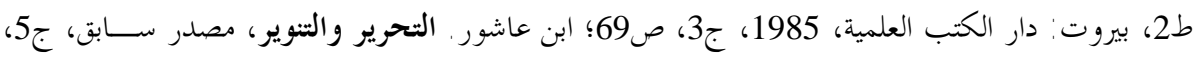

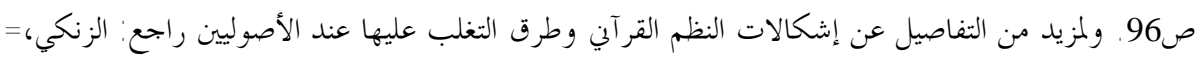


64 إسلامية المعرفة، السنة الثانية عشرة، العدد 48، ربيع 1428هـ/2007م بخم الدين قادر كريم الزنكي

أما الشاطبي فيرى أن اللازم هو الالتفات إلى هميع الكام المتر ابط إذا كان نازلاً في قضية واحدة. وهذا يعين ضرورة الاستعانة .كمامات التزول تأريخاً وأسباباً

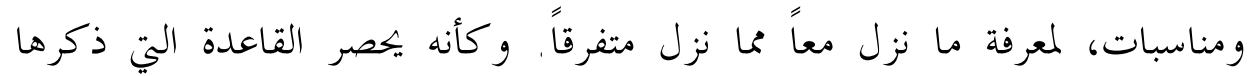
الجمهور في الشق الثاني فحسب، أما ما علمت وحلدة نزوله فالقاعدة فيه امتداد السياق بين جميع الأنحاء، يقول: "الذي يكون على بال من المستمع والمتفهم هو الالتفات إلى أول الكلام و آخره بحسب القضية وما اقتضاه الحال فيها. لا ينظر في أولها دون آخرها، ولا في آخرها دون أوها، فإن القضية وإن اشتملت على جمل فبعضها متعلق ببعض، لأفا قضية واحدة نازلة في شيء واحد، فلا محيص للمتفهم عن رد آخر

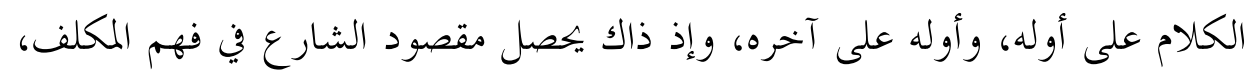
فإن فرَّق النظر في أجزائه فلا يتوصل به إلى مراده. فلا يصح الاقتصار في النظر على إلى بعض أجزاء الكلام دون بعض إلا في موطن واحد، وهو النظر في فهم الظاهر بكسب لئب اللسان العربي وما يقتضيه، لا بحسب مقصود المتكلم، فإذا صح له الظاهر على العربية

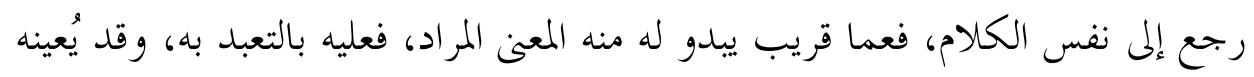

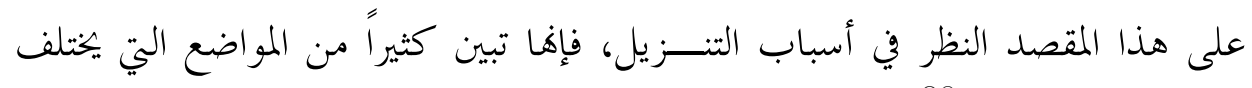
مغز اها على الناظر.

والغريب أن الشيخ ابن عاشور -وهو من أئمة المقاصد - قد انتحى منحى

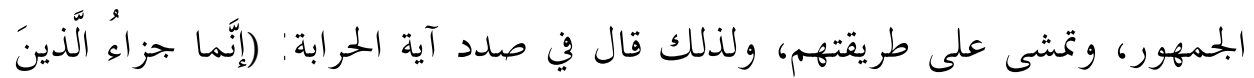

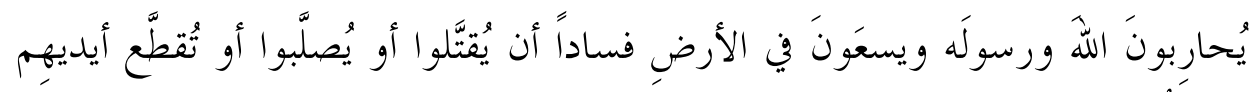

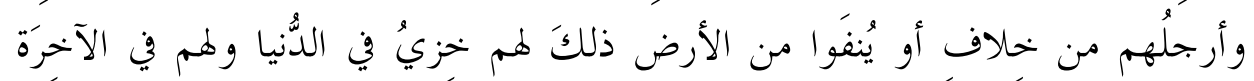

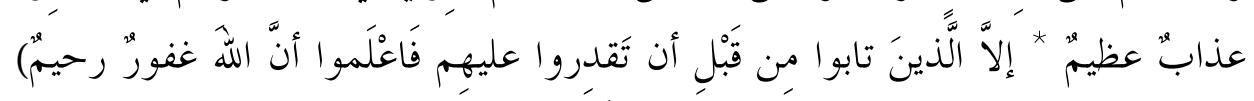

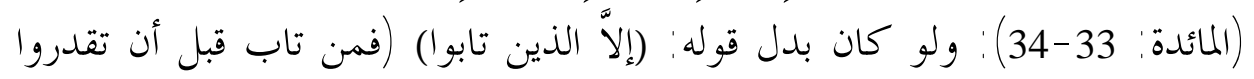

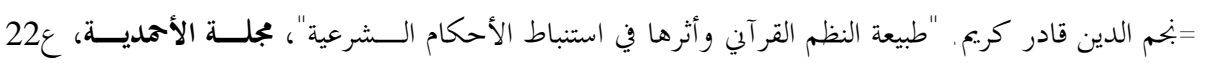

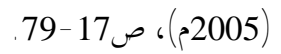
93 الشاطبي. الموافقات، مصدر سابق، مج2، ج3، ص375. 
عليهم) لم تدل الآية على قبول التوبة منهم إلاَّ في إسقاط العقاب الأخروي. 94 وهو يشير بذلك إلى آية السرقة التي جاءت التوبة فيها في جملة مستقلَّة عن آية العقوبة،

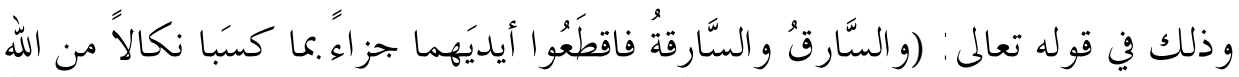

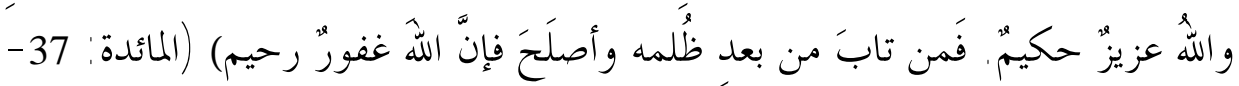
95 . (38

\section{رابعاً: تصورات تحليلية في الصلة بين السياق والمقاصد}

بعد أن عرفنا معنى السياق والمقاصد وتصورات الأصوليين لأحكام الدلالة السياقية، يجدر بنا هاهنا - ونحن نشرف على ختام البحث - أن نعرِج على بيان

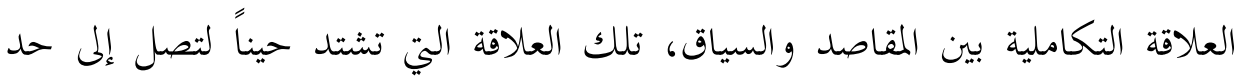
الإلغاز في بعض الأذهان و التصورات، حتى صار كثيرون يستغربون و جهه اقتصار الشاطبي عند بيان مسالك الكشف عن مقاصد الشارع على مسالك عدة معدودة مع وجود مسالك أخرى كثيرة لصيقة بالمقاصد نظراً لتوفرها على دلالات لفظية أو عقلية تلازمية هي مظنة إدراك مقاصد الشرع من الخطاب. ومن ذلك استشكال الدكتور

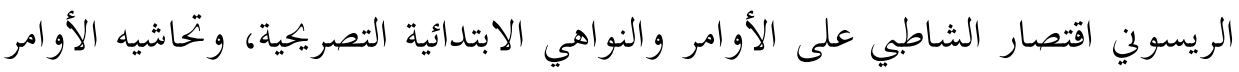

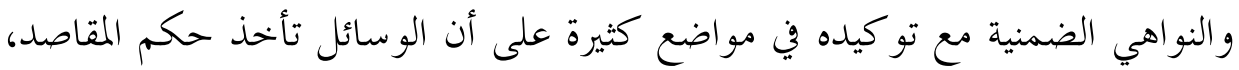

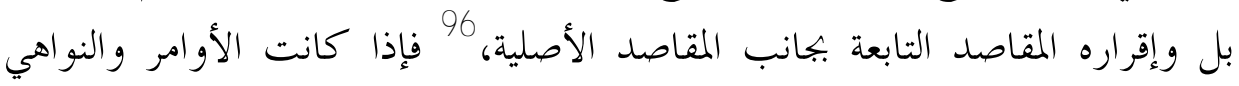
الابتدائية التصريكية مسلكاً إلى المقاصد الأصلية فلتكن غير الابتدائية وغير التصريكية مسلكاً إلى المقاصد التبعية التي هي من جنسها. ثم إن الشاطبي في موضع آخر يؤكد نوعاً من أنواع المساقات في الأوامر و النواهي مبنياً على استخراج المناسبات الشرعية إنسات

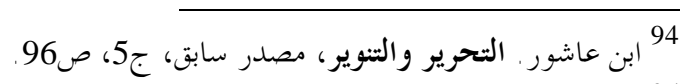

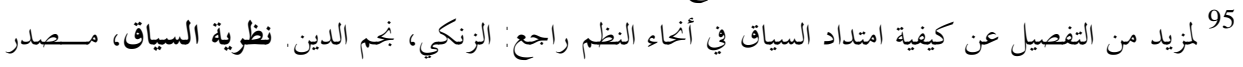

$$
\text { سابق، ص252 -293. }
$$

$$
96 \text { الريسو ني، نظرية المقاصد عند الإمام الشاطبي، مصدر سابق، ص302. }
$$


66 إسلامية المعرفة، السنة الثانية عشرة، العدد 48، ربيع 1428هـ/2007م بخم الدين قادر كريع الزنكي

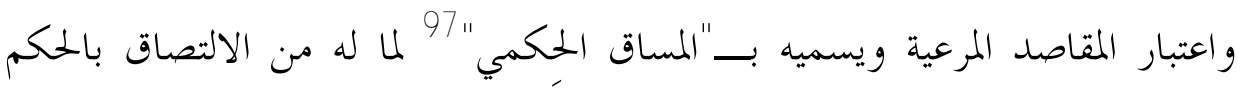

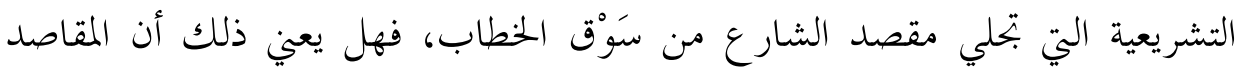

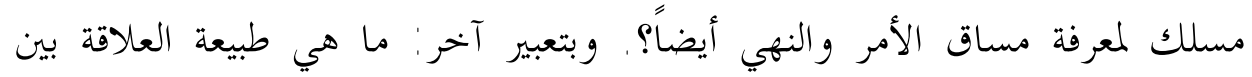

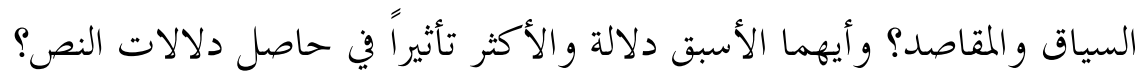
في جواب هذا السؤ ال وإشكالات أخرى من نوعه نقدم التصورات الآتية:

(1) بادئ ذي بدء، يجب أن نبيّن حقيقة هامة تتعلق بطبيعة كل من السياق

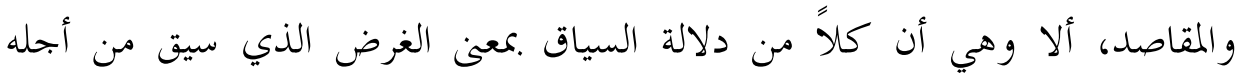

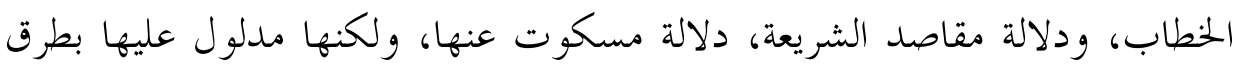

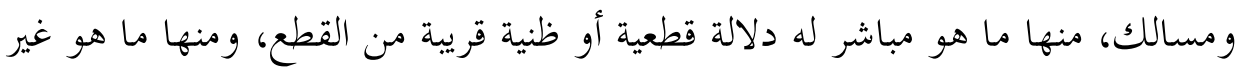

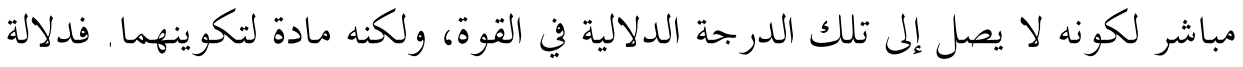

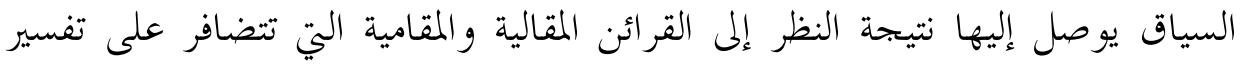

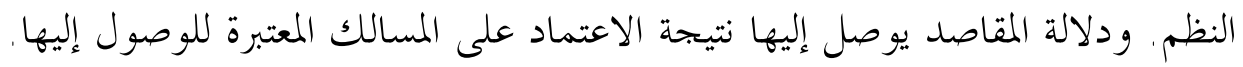

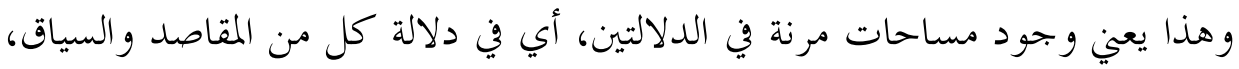

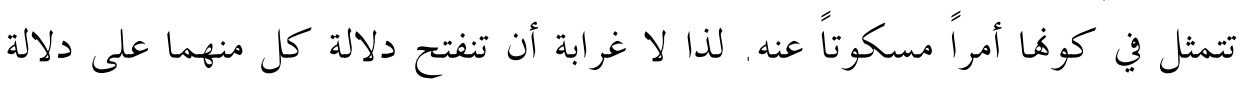
الآخر في تلك المساحة المرنة، ويصبح كل منهما قرينة من القرائن المفيدة في الآخر . هذا من الناحية النظرية. أما من الناحية العمليَّة فإننا بند أن الشاطبي التفت إلى فئل

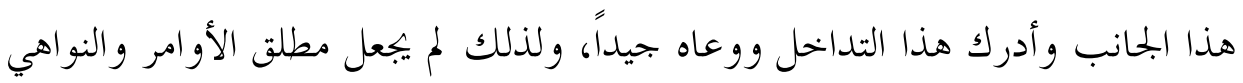

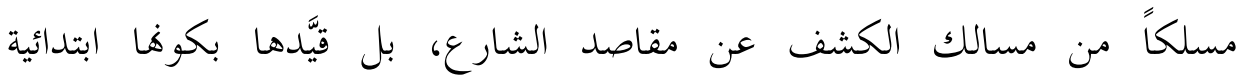

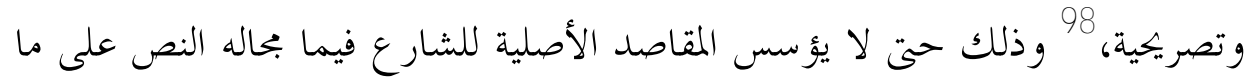

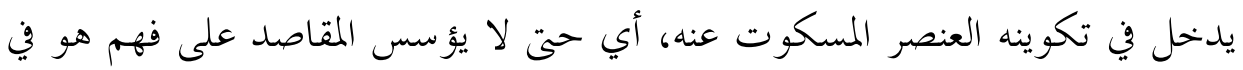

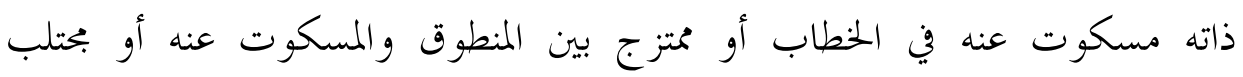

97 الشاطي. الموافقات، مصدر سابق، مج2، ج3، ص140 -141، وانظر أيسضاً ــــ، ج3، ص187 -188، ص244-245. 98 المصدر السابق، مج1، ج2، ص667 وما بعدها. 
بالإضمار والتأويل. أما في مسلك السكوت الدال على مقاصد الشارع فإنه اعتمد

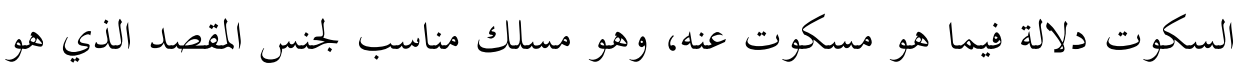

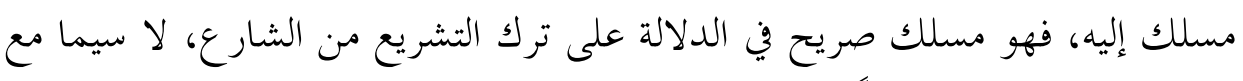

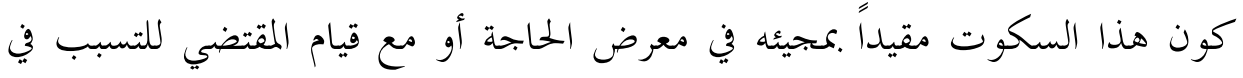

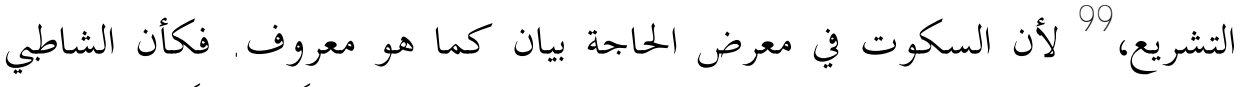

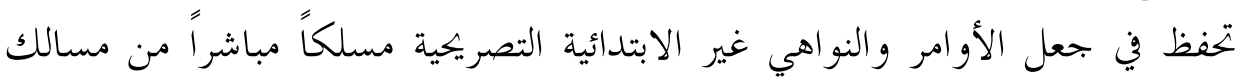

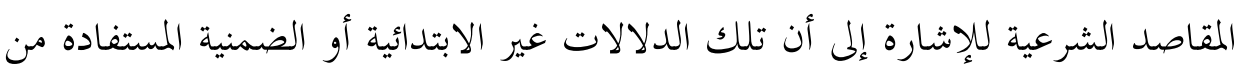

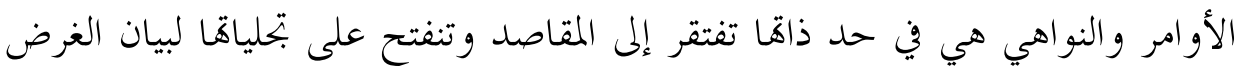

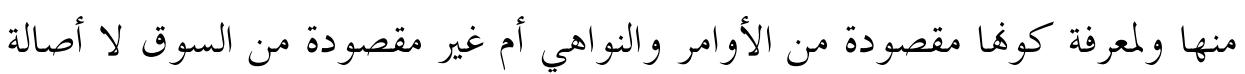

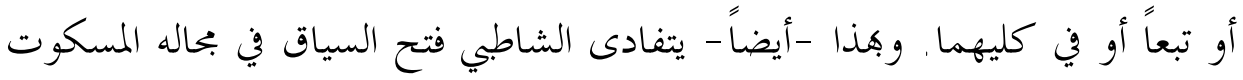

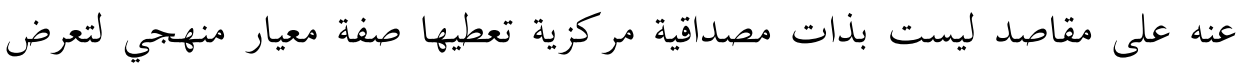

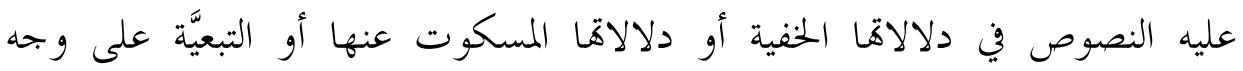

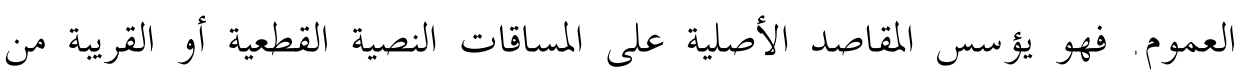

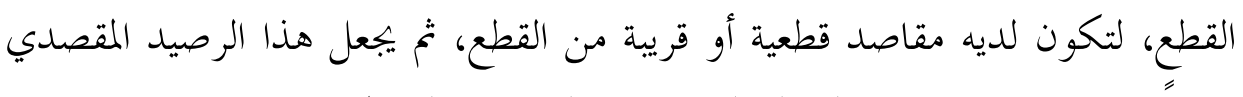

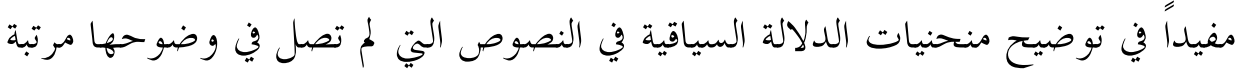
"النص".

تم إن المقاصد الأصلية مسلك من مسالك الكشف عن المقاصد التبعيَّة ومرجع المعاد

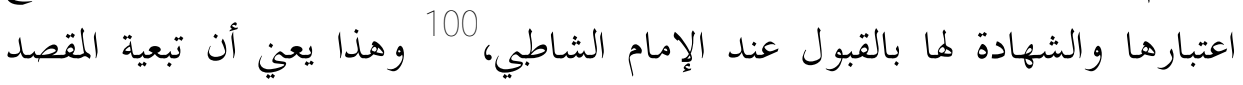

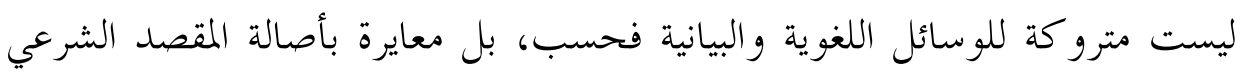

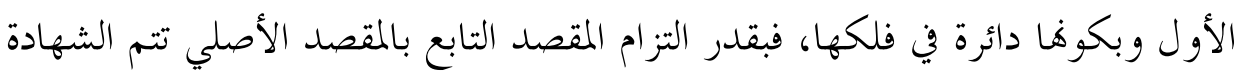

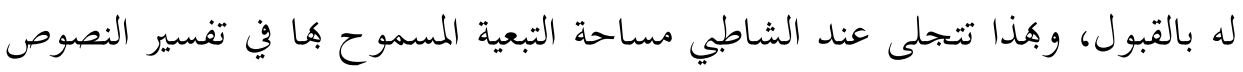

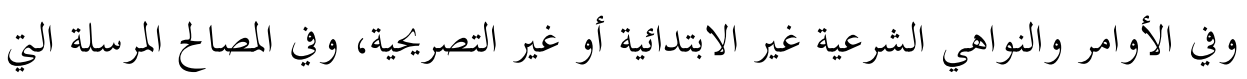

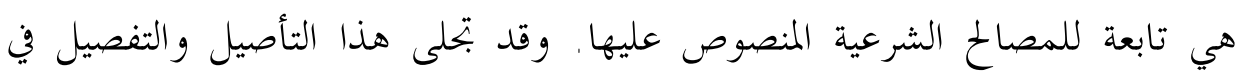

$$
\begin{aligned}
& \text { 99 المصدر السابق، مج1، ج2، ص681 وما بعدها. } \\
& 100 \text { المصدر السابق، مج1، ج2، ص670، ع67 وما بعدها. }
\end{aligned}
$$


مناقشة الشاطبي جمهور الأصوليين في تمسكهم بدلالة إشارة النص واعتبارهم أها من

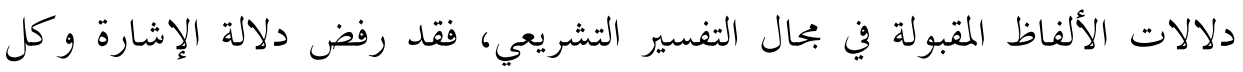

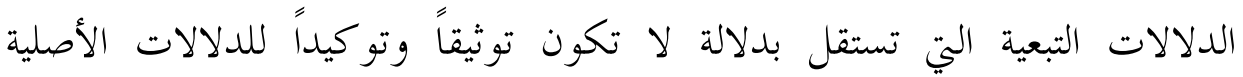

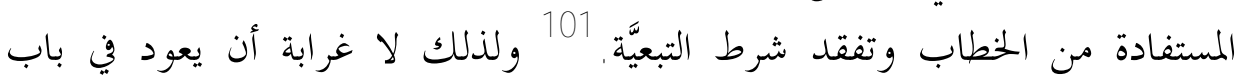
المقاصد فيجعل تلك الدلالات المقصدية الأصلية وسيلة للكشف عن ونس المقاصد التبعية،

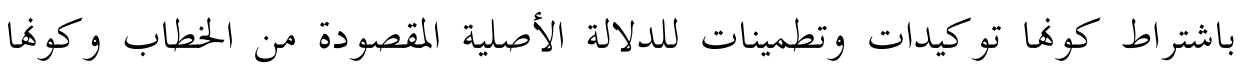
تجتمع حول نواة الدلالة التي تشكل مركز المعنى في الخطاب. ولذلك يجب ولت أن لا يفهم من الشاطبي أنه يجعل الدلالات التبعية بجملتها مقصودة للشار ع من النصوص كمر كما هي معروفة عند الجمهور، بل المقصودة منها هي الدلالات الموثقة المؤكدة للغرض الأصلي المقصود للشارع. ويوضح الشاطبي ما يرمي إليه بمثال النكاح، "فإنه مشروع للنناسل

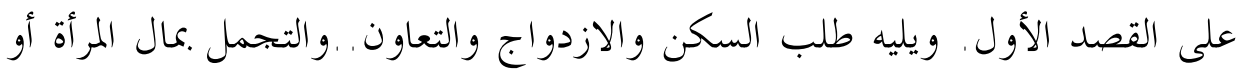

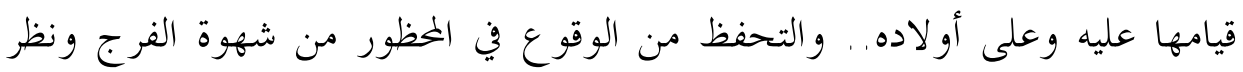

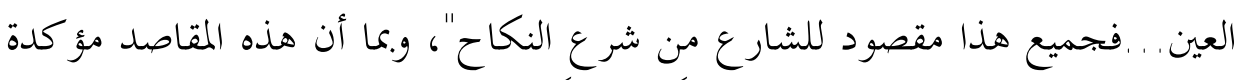

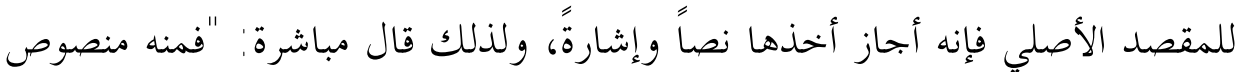

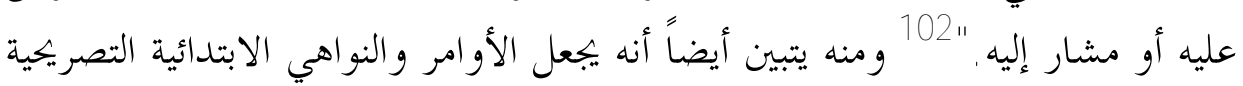

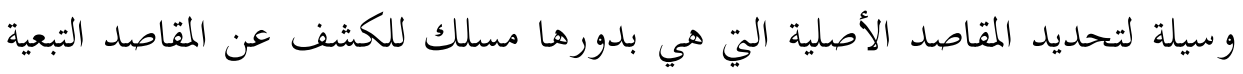

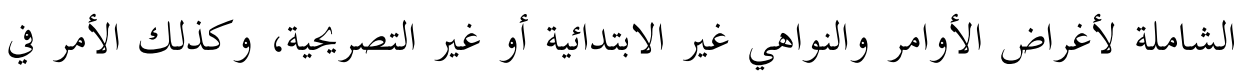

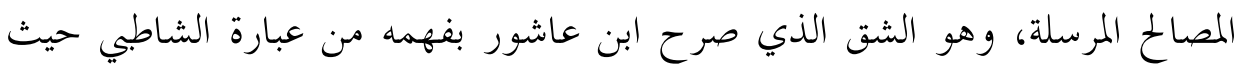

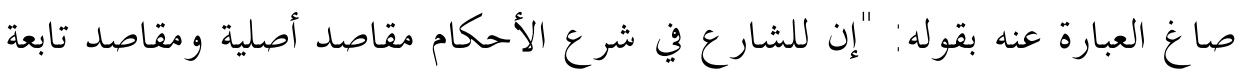

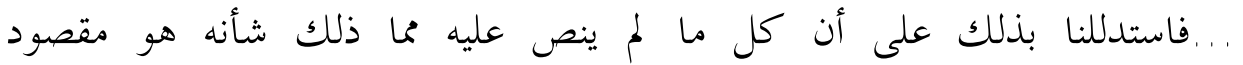
للشارع."103 وقد نبهنا على هذه الحقيقة المنهجية في نظرية الشاطبي لأن الغفلة عنها تجرنا إلى ما لا يحمد من خلط المفاهيم والاصطلاحات الذي لا يغتفر مثله في بحال

البحث العلمي.

$$
\begin{aligned}
& 101 \text { المصدر السابق، مج1، ج2، } 410 \text { وما بعدها. }
\end{aligned}
$$

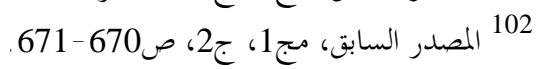

$$
\begin{aligned}
& 103 \text { 1ابن عاشور . مقاصد الشريعة الإسلامية، مصدر سابق، ص129. }
\end{aligned}
$$


(2) السياق وسيلة من وسائل التوصل إلى مقاصد الشارع، لكونه وسيلة من

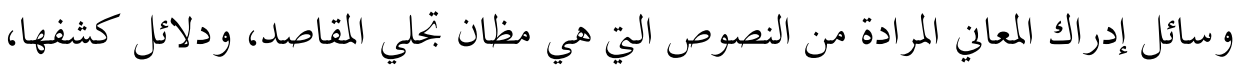

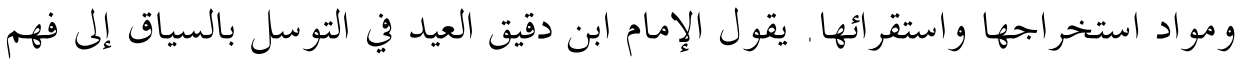

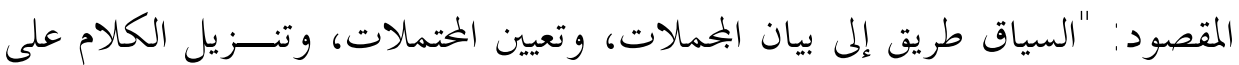

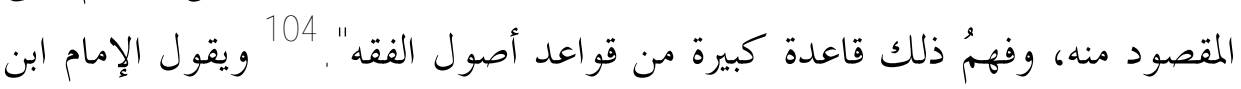

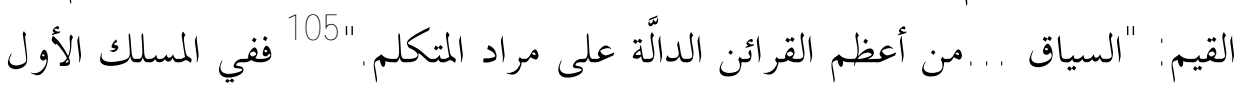

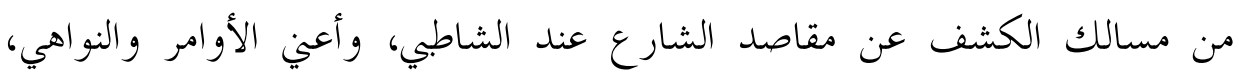

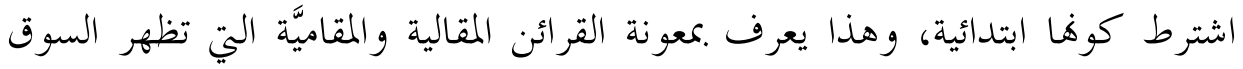

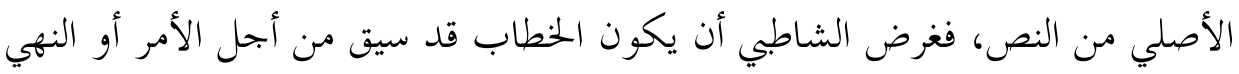

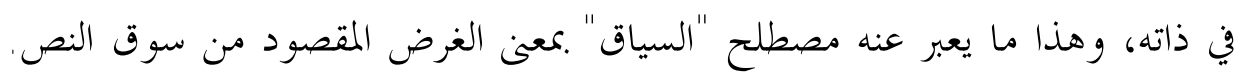

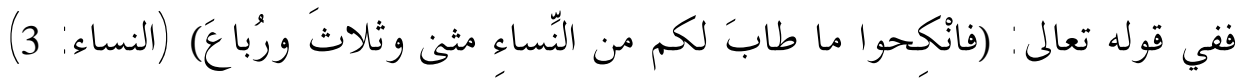

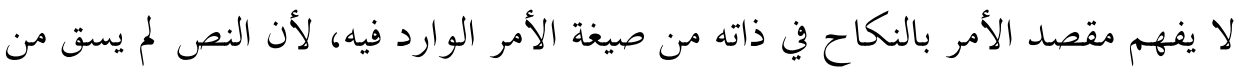

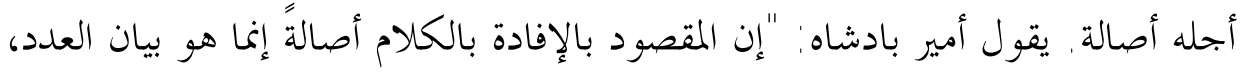

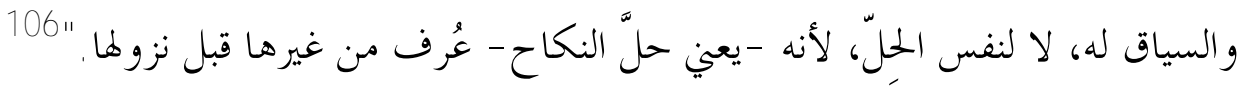

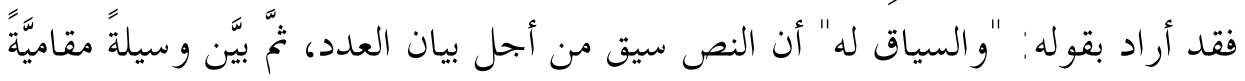

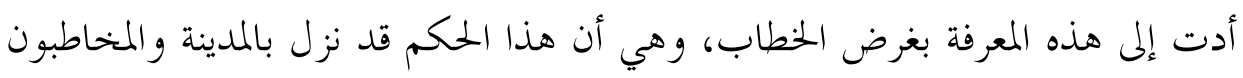

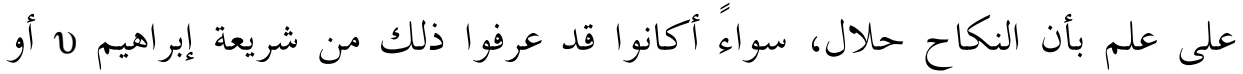

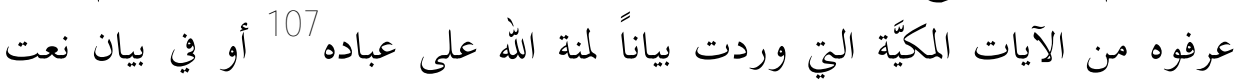

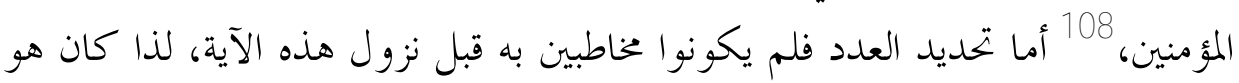

$$
\begin{aligned}
& 104 \text { ابن دقيق العيد. إحكام الأحكام شرح عمدة الأحكام، مصدر سابق، مج2، ج4، ص83. }
\end{aligned}
$$

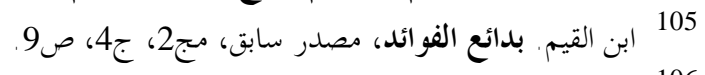

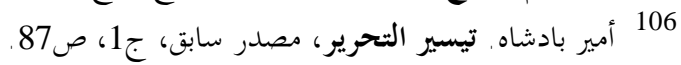

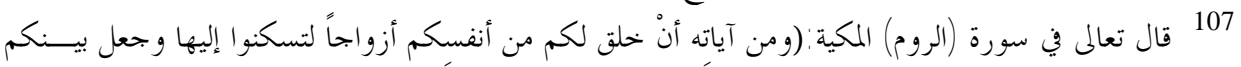

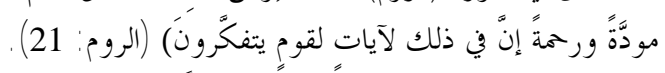

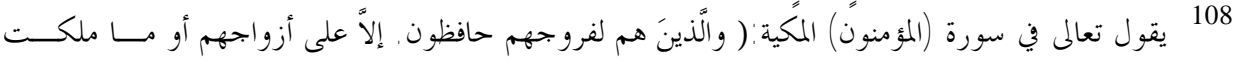

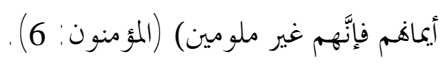




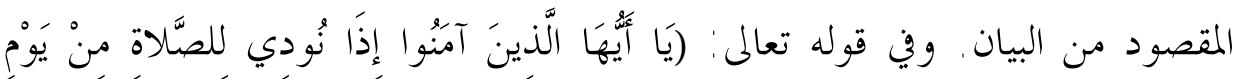

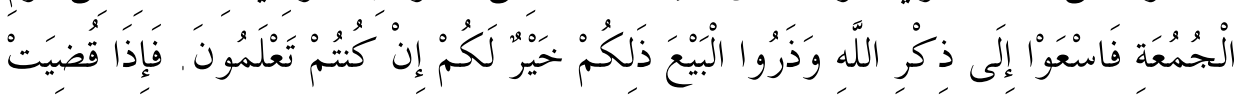

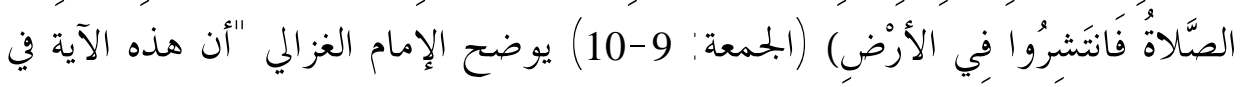
سورة الجمعة إنما نزلت وسيقت لمقصد، وهو بيان الجمعة...وما نزلت الخعالت الآية لبيان

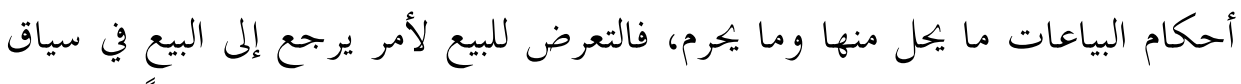

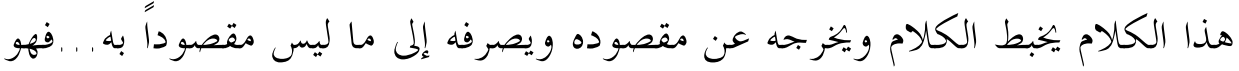

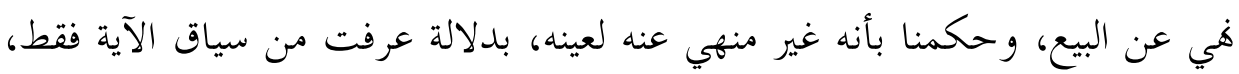

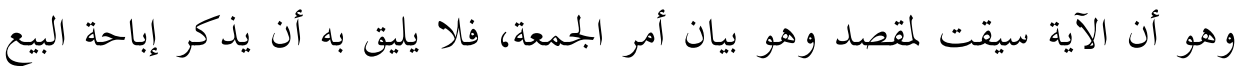

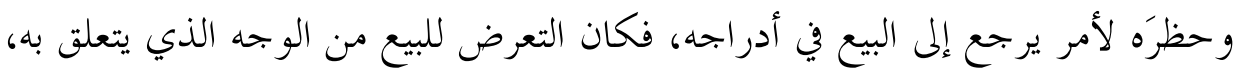

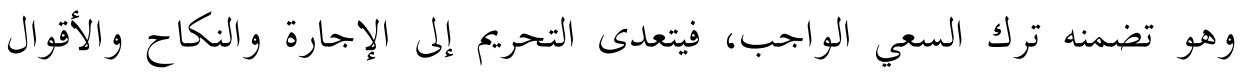

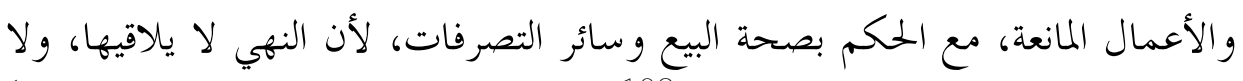

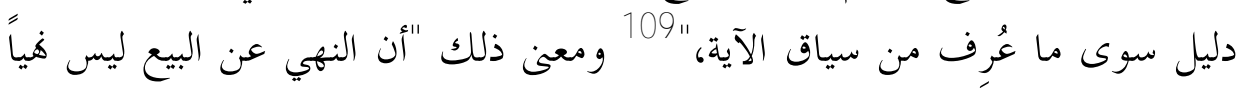

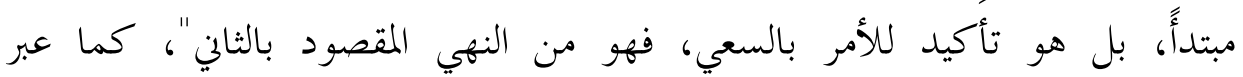

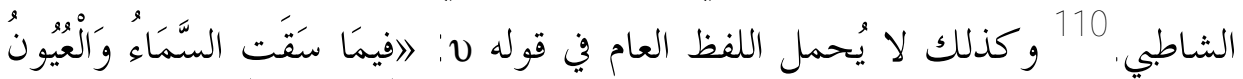

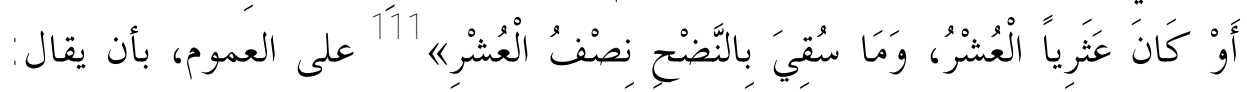

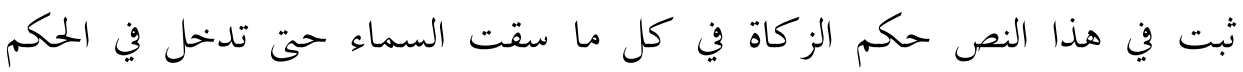

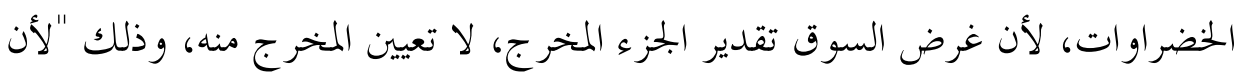

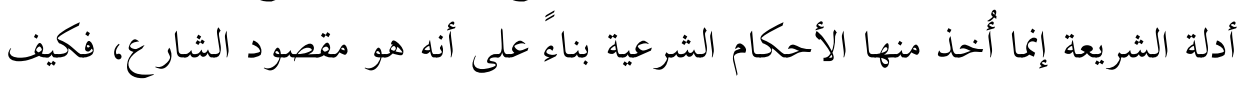

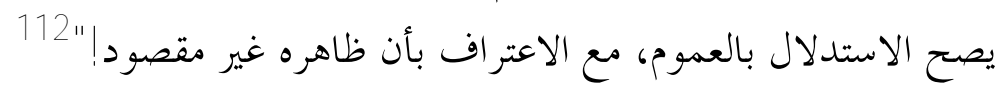

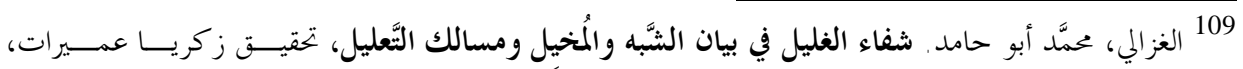

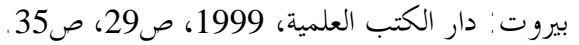

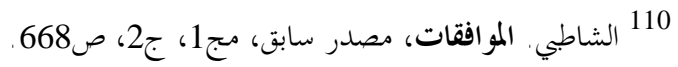

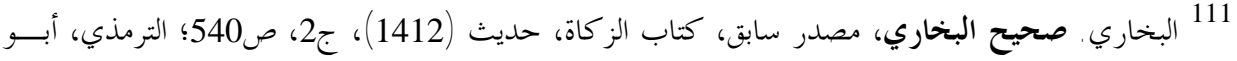

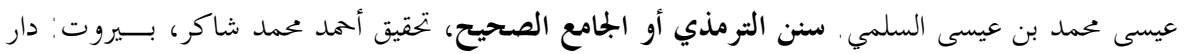

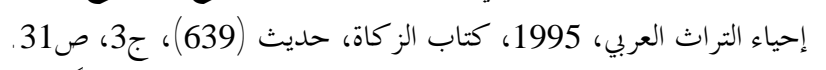

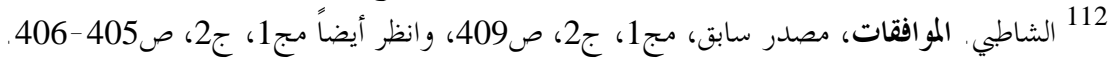




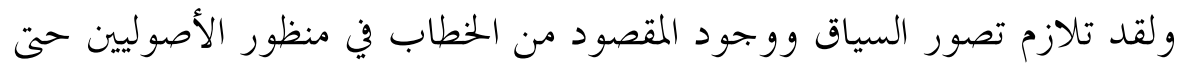

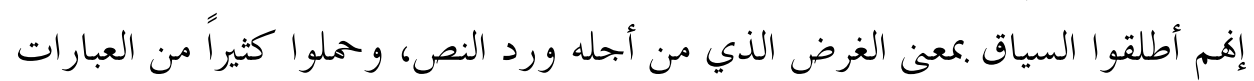

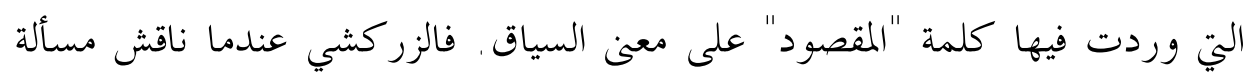

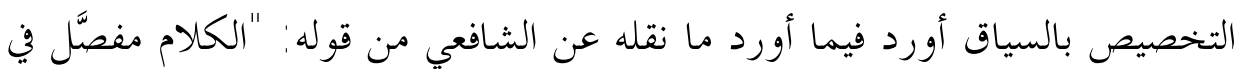

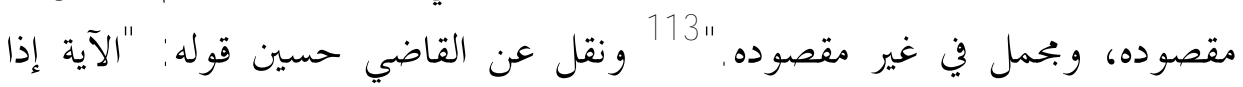

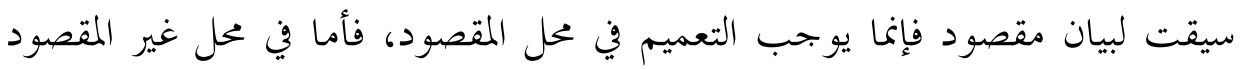

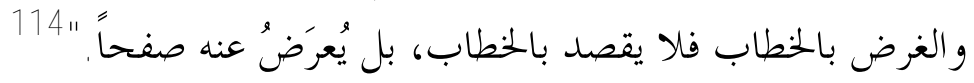

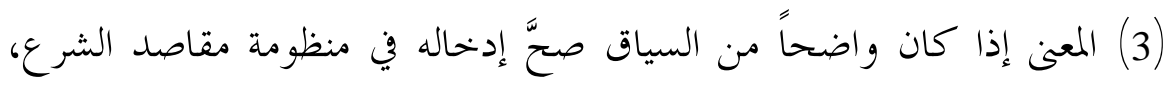

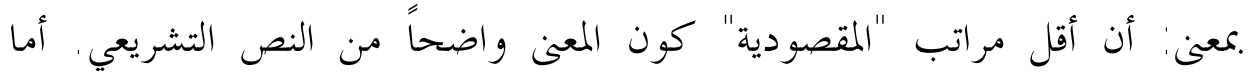

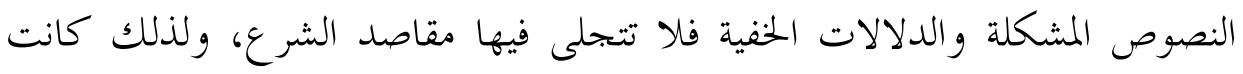

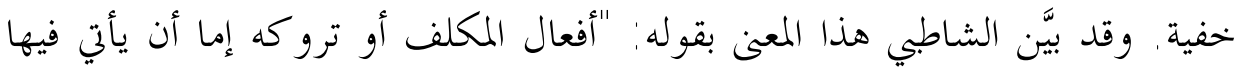

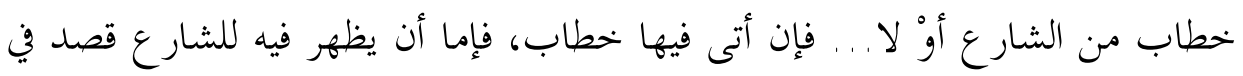

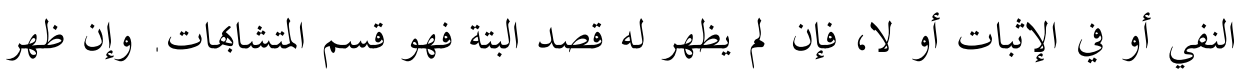

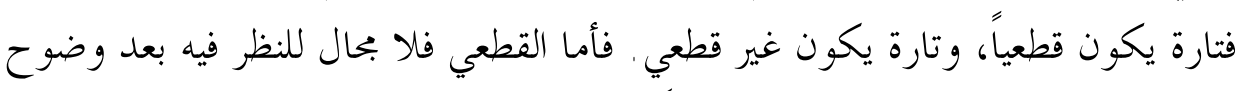

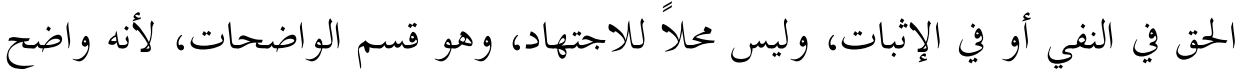

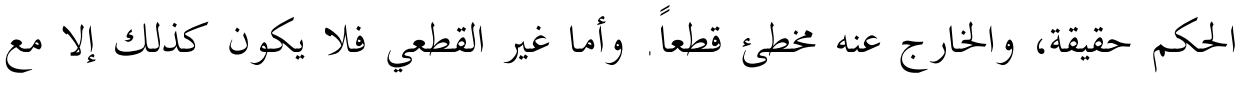

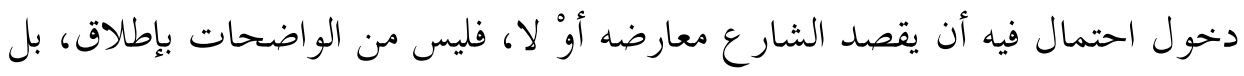

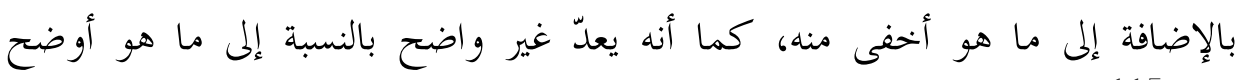
منه."115 ويفهم من هذه العبارة أن مراتب الأدلة عنده كما يأتي:

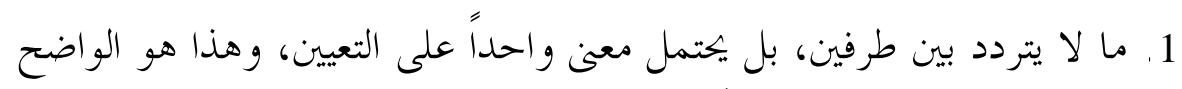
القطعي لذاته، ومقصود للشارع قطعاً.

$$
\begin{aligned}
& \text { 1113 الزركشي. البحر الخيط في أصول الفقه، مصدر سابق، ج4، ص265. }
\end{aligned}
$$

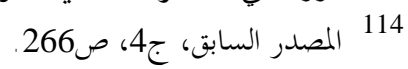

$$
\begin{aligned}
& 115 \text { الشاطبي. الموافقات، مصدر سابق، مج2، ج4، ص514 -5260. }
\end{aligned}
$$


72 إسلامية المعرفة، السنة الثانية عشرة، العدد 48، ربيع 1428هـ/2007م بخم الدين قادر كريم الزنكي

2. ما يتردد بين طرفين من المعنى، لكن ظهر قصد الشارع في أحدهما ظهوراً

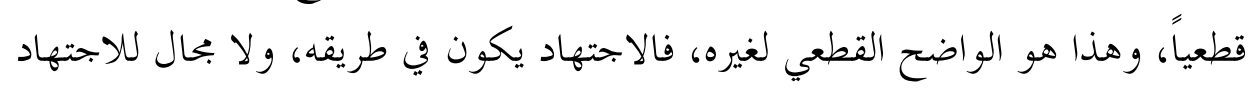
فيه بعد وضوح قصد الشارع في المعنى.

3. ما يتردد بين معنيين من شأن كل منهما أن يظهر قصد الشارع فيه، لكن ظهر

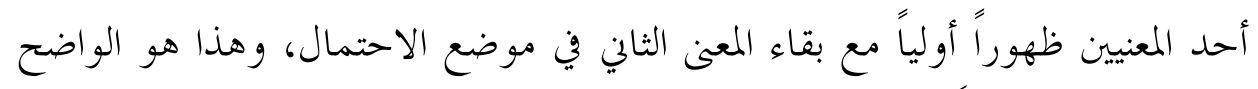

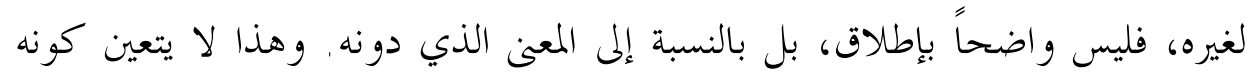
مقصوداً للشارع، ولكنه مقصود بالإضافة إلى ما هو دونه.

4. ما يتردد بين معنيين، لكن لا يظهر قصد الشارع للمجتهد في طرف من الطرفين لا قطعاً و لا ظناً، فهو متشابه. 116

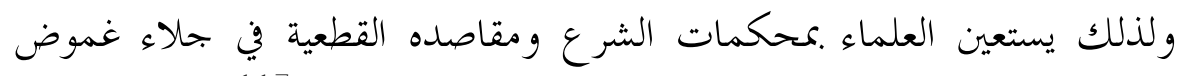
النص، و حل إشكاله، فقد قالو ا: "لا بدَّ من رد المتشابه إلى المخكم."117

وهذا يعني أن السياق إذا لم يكن و اضح الدلالة على المعنى فإن المقصد الشرعي

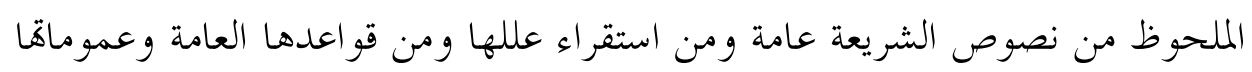

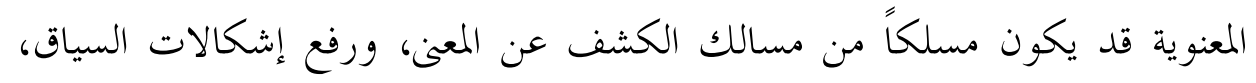
وحل معضالاته، وبتحلية مو اطن الحفاء فيه. 118

ومن أمثلة ذلك ما ذكره العلامة الكاساني (ت587هـ) في تفسير لفظة "أنّى" من

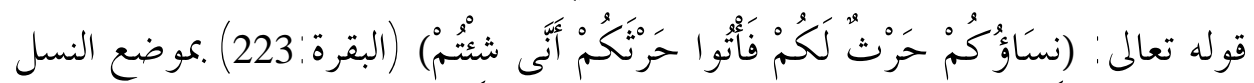

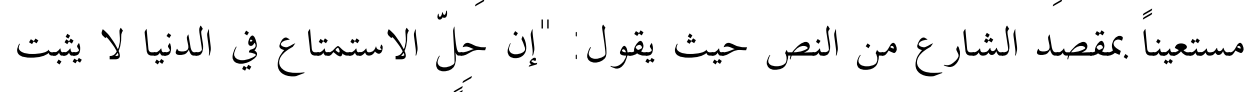

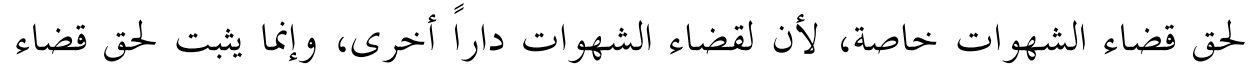

116 الزنكي، بخم الدين قادر كريه. الاجتهاد في مورد النص دراسة أصولية مقارنة، بيروت: دار الكتب العلميـة، 2006، ص222 -224.

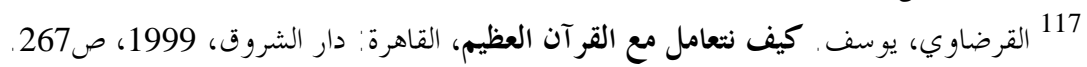

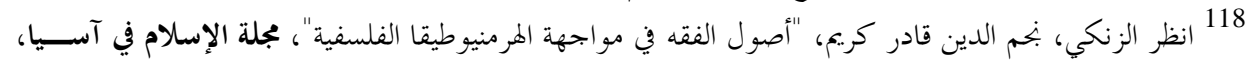

$$
\text { مج3، عا (يوليو 2006م)، } 37 \text {-38. }
$$


الحاجات، وهي حاجة بقاء النسل إلى انقضاء الدنيا، إلا أنه ركبت الشهوات في البشر

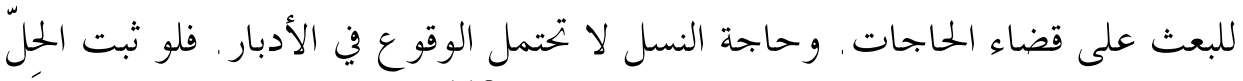

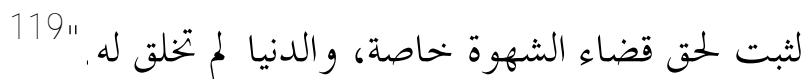

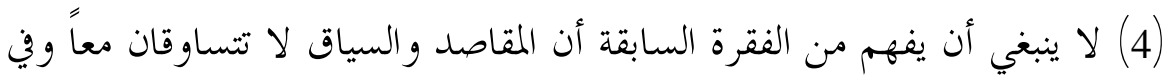

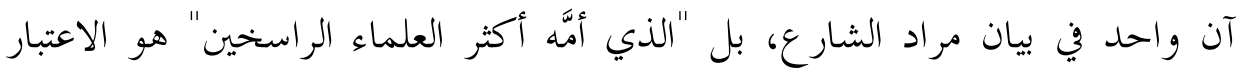

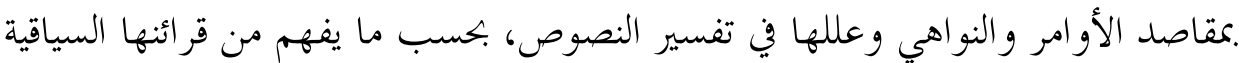

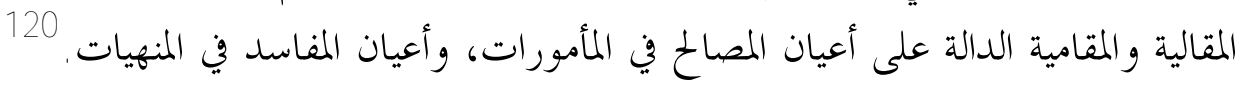

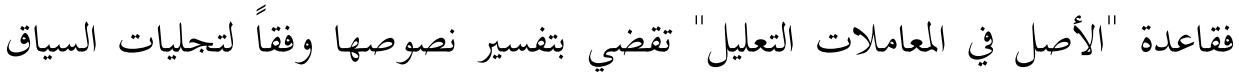

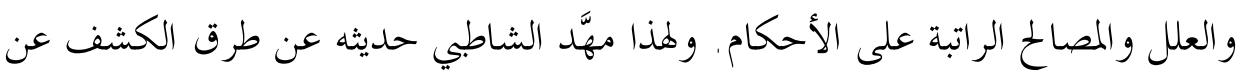

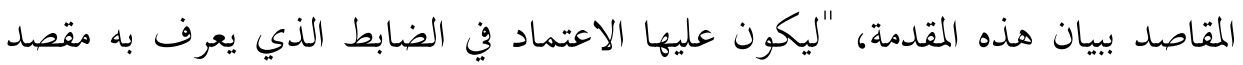

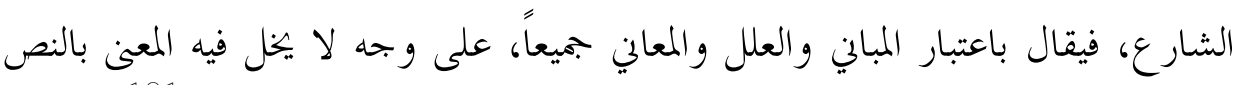

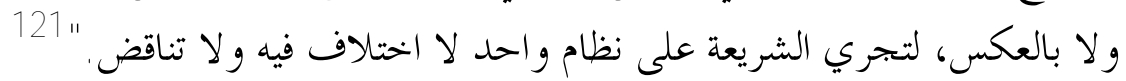
فإذا كانت الأوامر والنواهي من مسالك الكشف عن المقاصد فإها "من جهة

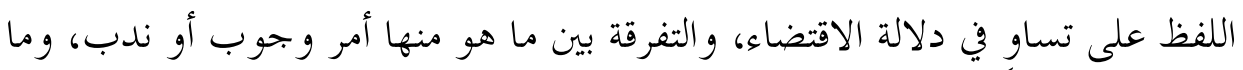

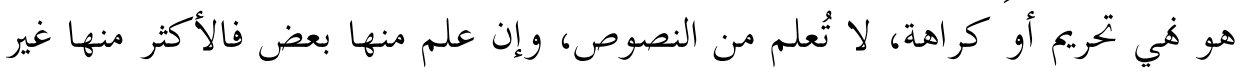

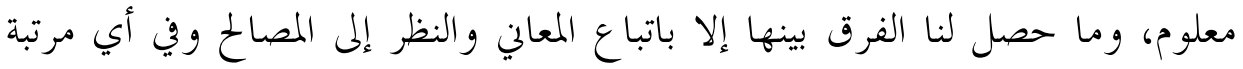

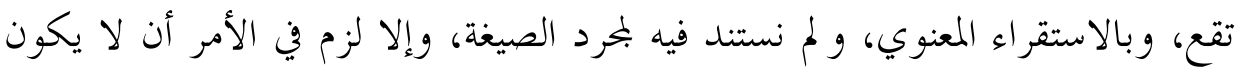

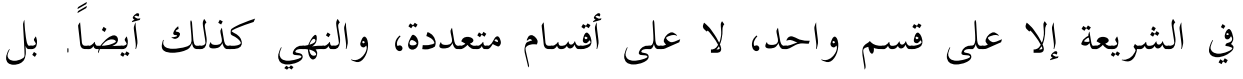
نقول: كلام العرب على الإطلاق لا بد فيه من اعتبار معنى المساق في دلالة الصيغ، وإلا صار ضحكة وهز أة."122

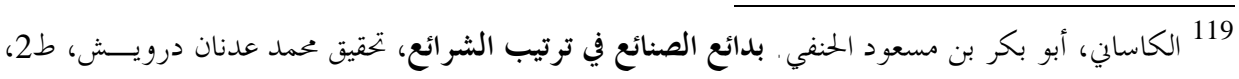

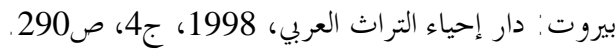

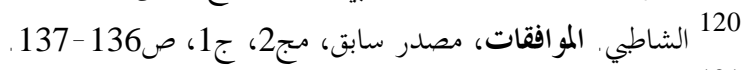

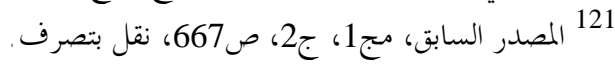

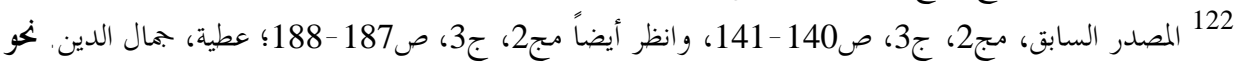

$$
\text { تفعيل مقاصد الشريعة، دمشق: دار الفكر، 2001، ص63 -69 -69. }
$$


74 إسلامية المعرفة، السنة الثانية عشرة، العدد 48، ربيع 1428هـ/2007م بخم الدين قادر كريم الزنكي

ولعلَّ هذا السبب هو الذي جعل الشاطبي يذكر قسماً خاصاً من أنواع المساقات

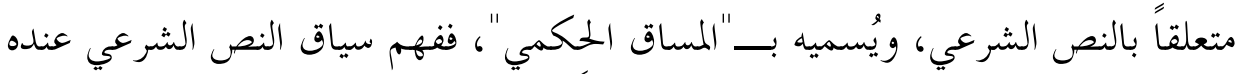

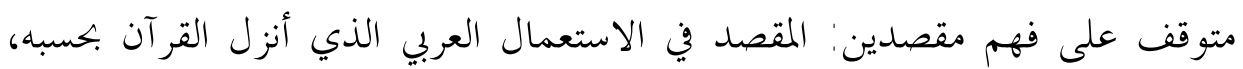
والمقصد في الاستعمال الشرعي الذي تقرَّر في نصوص الشريعة وقواعدها. ووهذا

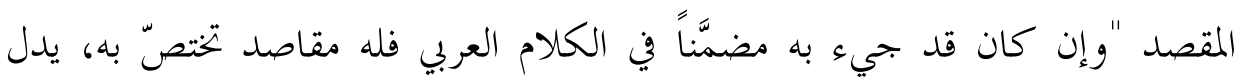

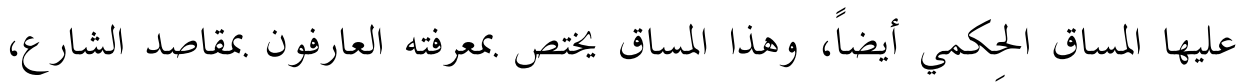

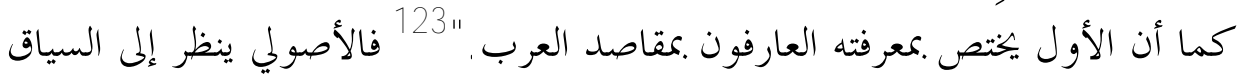

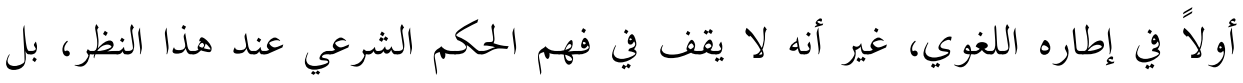

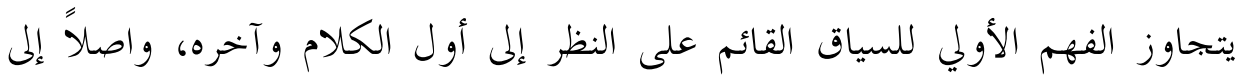

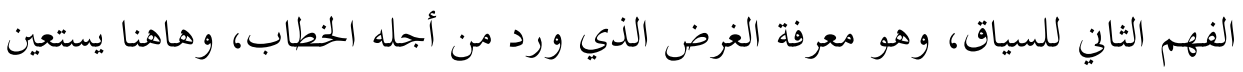
بالمساق الحكمي الذي يتكشنَف نتيجة النظر في عادات الشارع و ومقاصده بعد النظر في الني

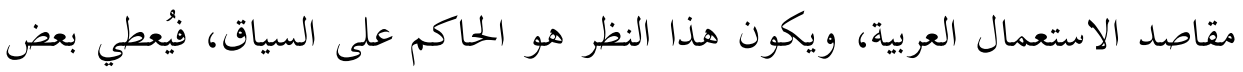

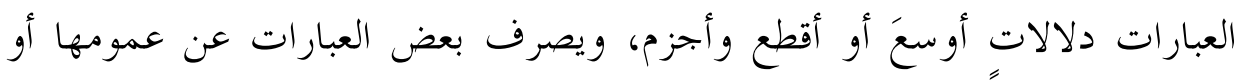

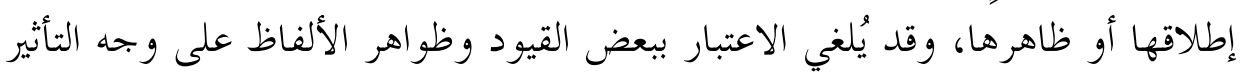
في الحكى. 124

وومن أمثلة ذلك ما ذكره الإمام الغزالي من أن "من الألفاظ والأسامي ما يجري على اللسان ذكرها و لا يكون مقصوداً، ويُعرف ذلك بيجري العادة في النَّْم، كقوله

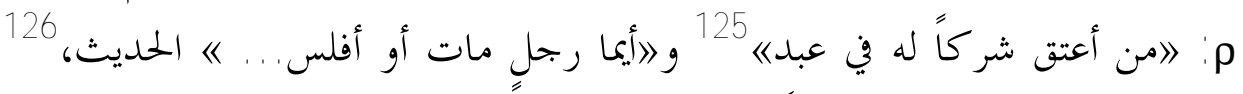

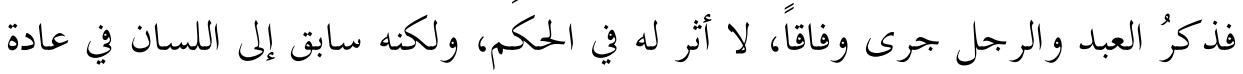

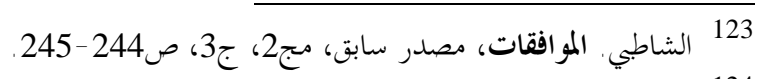

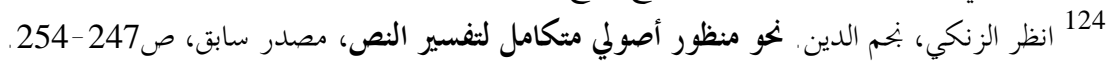

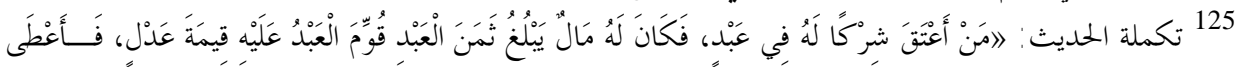

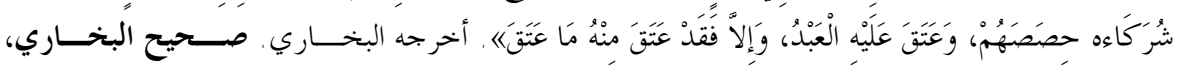

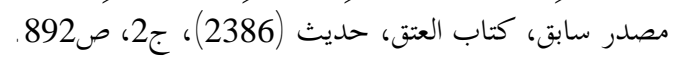

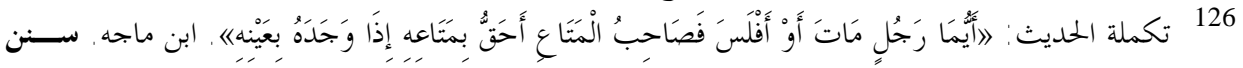

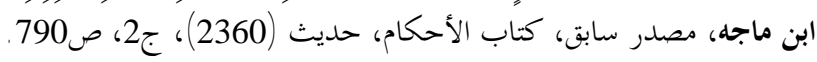


البيان بتغليب الذكور في الذكر على الإناث، ويقرُب من هذا الجنس قوله تعالى:

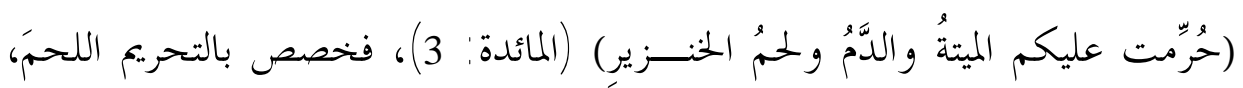

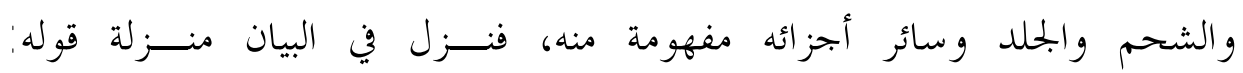

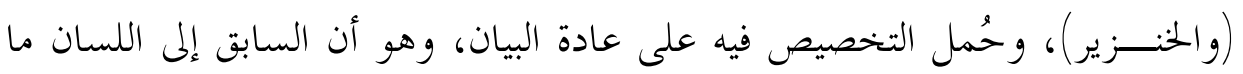

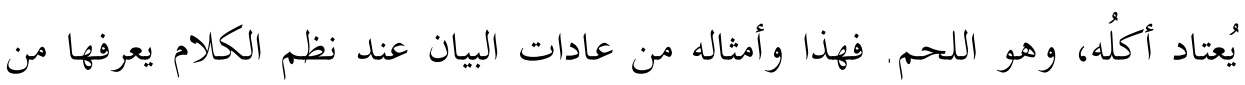

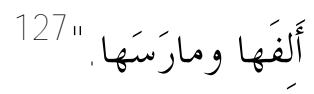

وبإهمال هذا المساق الحكمي، أو عدم تقديره تقديراً سليماً بصدوره عن معرفة أنسا

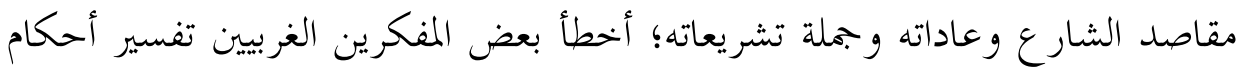

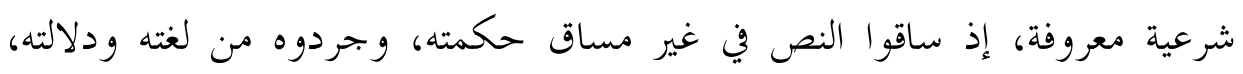

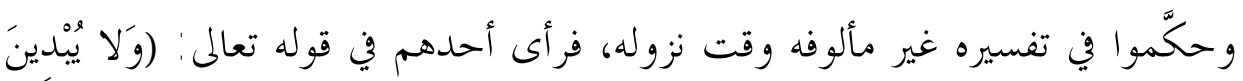

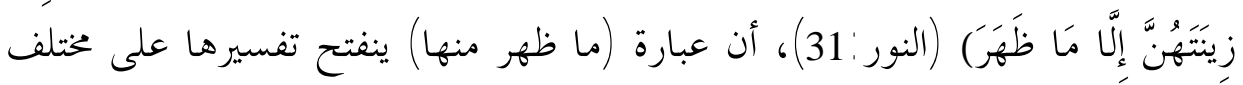

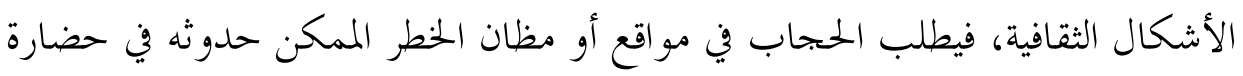

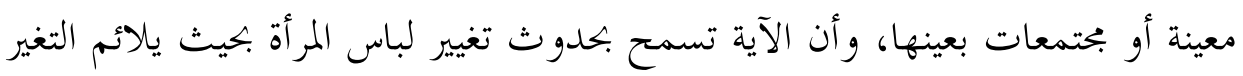

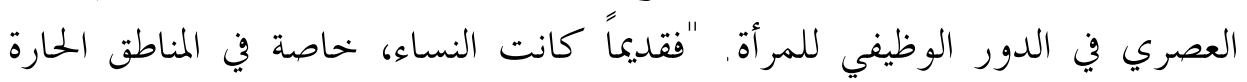

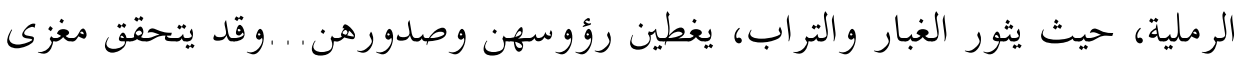

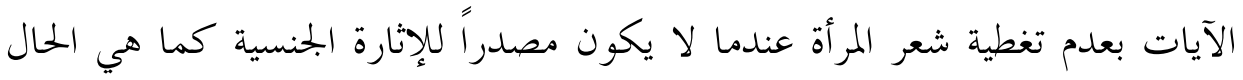

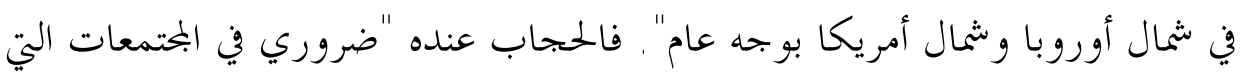

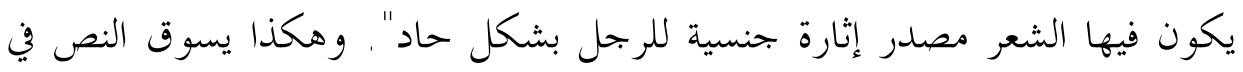

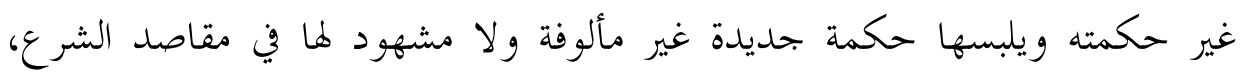

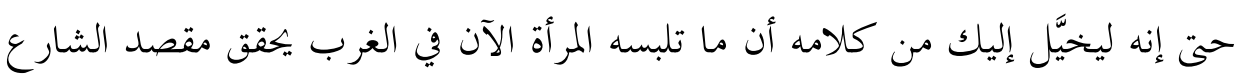

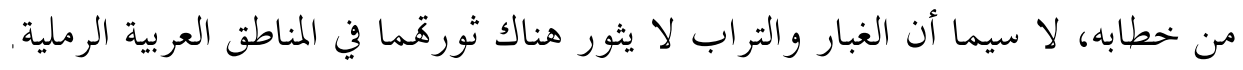

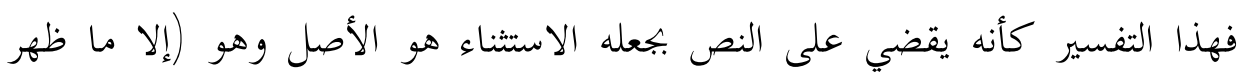

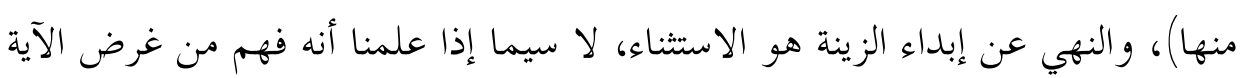


76 إسلامية المعرفة، السنة الثانية عشرة، العدد 48، ربيع 1428هـ/2007م بخم الدين قادر كريم الزنكي

ومساقها أها "لم تفرض أن تغطي تلك الطرحة أو ذاك المنديل ثديي المرأة أو صدرها،

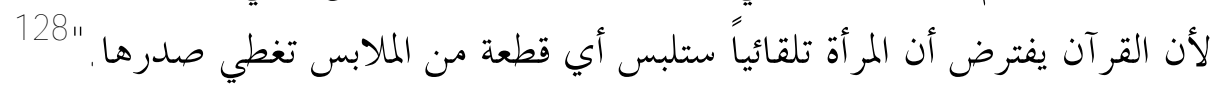

\section{الحخـــاتمــــة}

نخلص مما تقدم إلى أن للسياق ونظريته الأصولية صلة وثيقة بالمقاصد ونظريتها،

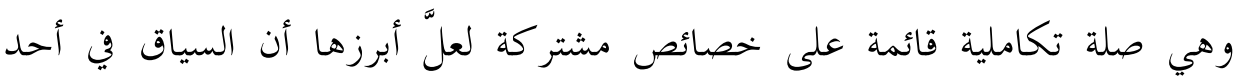
إطلاقيه الشائعين عند الأصوليين جاء .كعنى الغرض الذي جاء الخطاب لأجله. ولقد جمع الشاطبي بين دلالتي السياق والمقاصد .مصطلح تركيي ذي مغزى علمي أصيل يشير إلى الوظيفة التكاملية للمصطلحين، وهو مصطلح "المساق الحكمي" الذي يتساوق فيه مقصد المبنى ومقصد المعنى، ويستوي فيه فهم النص التشريعي عند

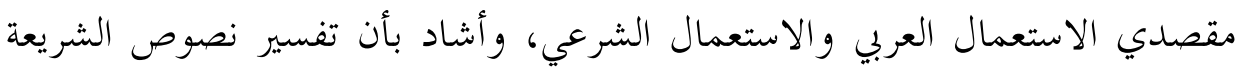

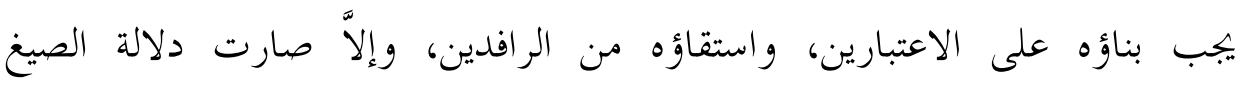
و العبارات هزأة وضحكة، إما بخلوها من اعتبارات الحلكم الملحوظة للتشريع أو بجعل

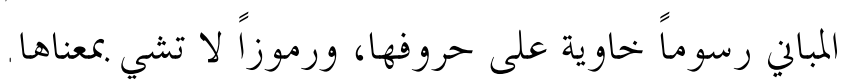

هذا على مستوى النظرية، أما على مستوى المصطلح فإن كلاً من مصطلحي

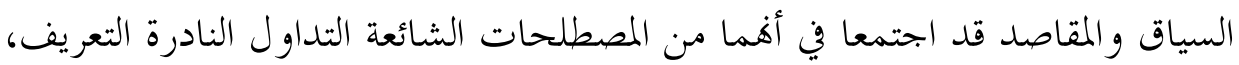

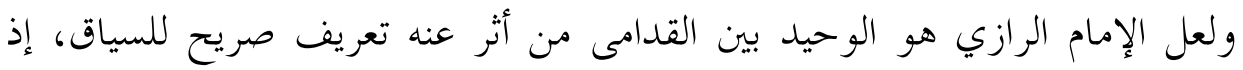
عرفه بأنه "كل ما يكتنف اللفظ الذي نريد فهمه من دوال أخرى"، و.بما أنه لم يقيد الدوالَّ باللفظية فإن تعريفه يتماشى مع التصور المحدث للسياق القائم على بعدين

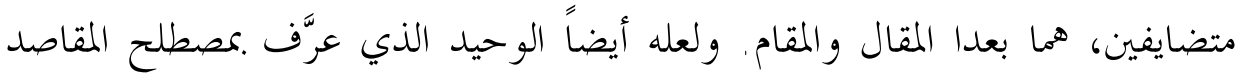
بقوله: "ما دلَّت الدلائل على وجوب بعلى تحصيله، والسعي في رعايته، والاعتناء

128 هوفمان، مراد ويلفريد. الإسلام كبديل، ترجمة غريب محمد غريب، الكويت: بحلة النور، 1993، ص217 - 
بحفظــه". وهذا التعريف الجامع المانع، أقوى صيغةً وأعمق دلالةً من التعريفات التي

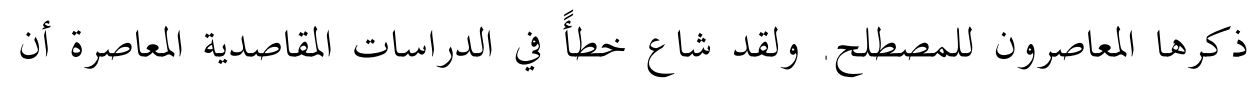

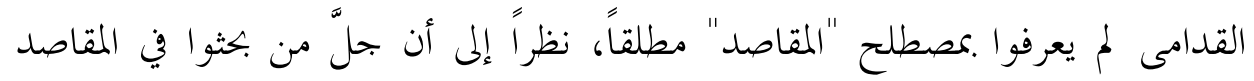

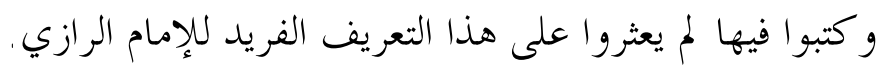

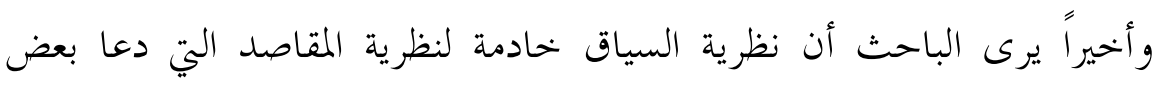

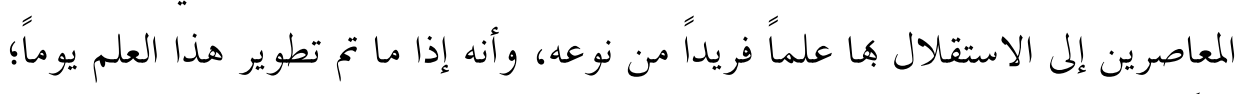

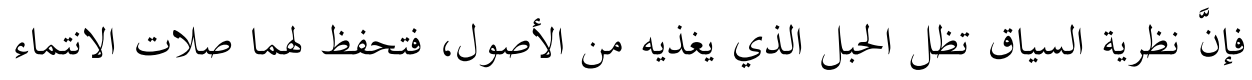

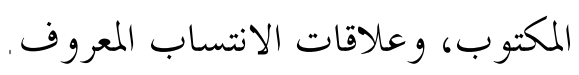

